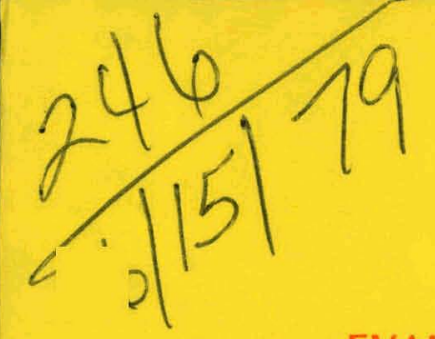

A.2739

\title{
MASTER Doermprasesan
}

EVALUATION OF SELECTED CHEMICAL PROCESSES FOR

PRODUCTION OF LOW-COST SILICON

Phases I and II

Final Report for October 9, 1975-July 9, 1978

By

J. M. Blocher, Jr.

M. F. Browning

Work Performed Under Contract No. NAS-7-100-954339

Battelle Columbus Laboratories

Columbus, Ohio

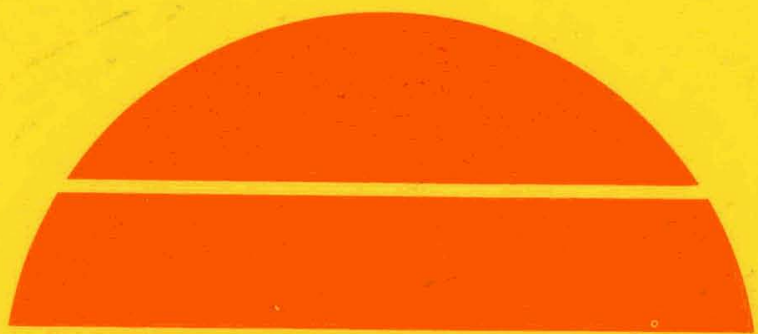

\section{U.S. Department of Energy}




\section{DISCLAIMER}

This report was prepared as an account of work sponsored by an agency of the United States Government. Neither the United States Government nor any agency Thereof, nor any of their employees, makes any warranty, express or implied, or assumes any legal liability or responsibility for the accuracy, completeness, or usefulness of any information, apparatus, product, or process disclosed, or represents that its use would not infringe privately owned rights. Reference herein to any specific commercial product, process, or service by trade name, trademark, manufacturer, or otherwise does not necessarily constitute or imply its endorsement, recommendation, or favoring by the United States Government or any agency thereof. The views and opinions of authors expressed herein do not necessarily state or reflect those of the United States Government or any agency thereof. 


\section{DISCLAIMER}

Portions of this document may be illegible in electronic image products. Images are produced from the best available original document. 


\section{NOTICE}

This report was prepared as an account of work sponsored by the United States Government. Neither the United States nor the United States Department of Energy, nor any of their employees, nor any of their contractors, subcontractors, or their employees, makes any warranty, express or implied, or assumes any legal liability or responsibility for the accuracy, completeness or usefulness of any information, apparatus, product or prncess disclosed. or represents that its use would not infrunge privately owned rights.

This report has been reproduced directly from the best available copy.

Available from the National Technical Information Service, U. S. Department of Commerce, Springfield, Virginia 22161.

Price: Paper Copy $\$ 6.50$

Microfiche $\$ 3.00$ 
FINAL REPORT

Covering the Period October 9, 1975, to July 9, $1978^{\circ}$

on

\title{
EVALUATION OF SELECTED CHEMICAL PROCESSES FOR PRODUCTION OF LOW-COST SILICON
}

\author{
(Phases I and II)
}

\author{
JPL Contract 954339 \\ Silicon Material Task \\ Low-Cost Solar Array Project
}

to

JET PROPULSION LABORATORY CALIFORNIA INSTITUTE OF TECHNOLOGY

by

J. M. Blocher, Jr. and M. F. Browning

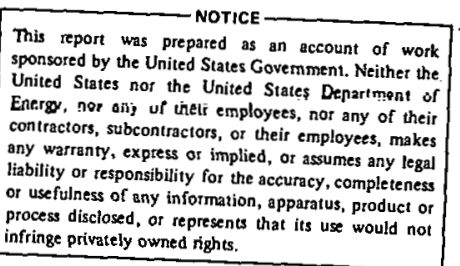

July 9,1978

This work was performed for the jet Propulsion Laboratory. California Institute of Technology, under NASA Contract NAS7-100 for the U.S. Department of Energy, Division of Solar Energy.

The JPL Low-Cost Solar Array Project is funded by DOE and forms part of the DOE Photovoltaic Conversion Program to initiate a major effort toward the development of low-cost solar arrays.

\section{BATTELLE}

Columbus Laboratories 505. King Avenue

Columbus, Ohio 43201 


\section{ACKNOWL EDGEMENT}

The authors gratefully acknowledge the capable assistance of the following Individuals in the performance of the work and preparac1on of this report: Mr. Erlan E. Rose, Mr. W1lllam B. Thompson, Mr. W11llam A. Schmitt, Mr. James S. F1ppin, Dr. RIchard W. K1dd, Mr. W1lbur J. W11son, Mr. D. C. Carmlchael, and Mrs. Pamela S. Kerbler of Battelle's Columbus Laboratorles; Mr. W. R. Ackley, Mr. Ḋ.W. Bennett, Mr. K. R. Kauplsch, Jr., añd Mr. W. W. KIIne of Raphael Kaczen Assoclates International, Inc., Cincinnat1, Oh1o; Mr. H. H. Walling, Mr. E. K. Jones, and assoclates of Pace Englneers, Inc., Houston, Texas; and Dr. Carl Yaws of Lamar Univers1ty, Beaumont, Texas. 
ACKNOWLEDGEMENT. . . . . . . . . . . . . . . . . . . . . . 11

ABSTRACT . . . . . . . . . . . . . . . . . . . . . 1

A. INTRODUCTION . . . . . . . . . . . . . . . . . . . . 3

B. EVALUATION OF CANDIDATE PROCESSES. . . . . . . . . . . . . . 5

Shntre of Process Scale. . . . . . . . . . . . . . . . 7

Approach to Economic Evaluation. . . . . . . . . . . . . . . 7

Results of Economic Analysis . . . . . . . . . . . . . . . . 12

Process A, Fluldized-Bed Zinc Reduction of $\mathrm{SiCl}_{4}$. . . . . . 13

Process B, Thermal Decomposition of $\mathrm{SiI}_{4}$ Product

from Metallurgical-Grade Silicon . . . . . . . . . . . . .

Process C, Thermal Decomposition of $\mathrm{SiI}_{4}$ Produced

by Iodination of $\mathrm{SiO}_{2}$-Carbon Mixtures. . . . . . . . . . . 17

Process D, Hydrogen Reduction of $\mathrm{S}_{4} \mathrm{I}_{4}$ in a Fluldized

Bed, Dry hI Recycle. . . . . . . . . . . . . . 20

Process E, Fluidized-Bed Hydrogen Reduction of

$\mathrm{SiI}_{4}$ with Wet-Process Iodine Recycle . . . . . . . . . . 22

Process F, Fluidized-Bed Hydrogen Reduction of $\mathrm{SiI}_{4}$

with Recirculation of Unseparated $\mathrm{HI} / \mathrm{H}_{2} \cdot . . . . .+. . . . . .33$

Processes A Through F Cost Summary . . . . . . . . . . . 22

Energy Consumption . . . . . . . . . . . . . . . 30

Experimental Hydrogen Reduction of $\mathrm{SiI}_{4}$. . . . . . . . . 30

Experfmental Iodination of $\mathrm{S} 10_{2}+C$ Mixtures . . . . . . . 33

C. ZINC REDUCTION PROCESS DEVELOPMENT . . . . . . . . . . . . . 36

Thermodynamic Analysis . . . . . . . . . . . . . . . 37

Effect of Stolchiometry on Product Cost. . . . . . . . . . . 40

Experimental Fluldized-Bed Zinc Reduction of $\mathrm{SiCl}_{4}$. . . . . . . . . 44 
Solld Versus Gaseous Zinc Feed . . . . . . . . . . . . . . . . 45

Use of Diluent or Carrler Gas. . . . . . . . . . . . 47

Fluld1zed-Bed Dynamics . . . . . . . . . . . . . . . . 48

Rate and Efficiency of S1licon Production. . . . ......... 52

Effect of Reactant Throughput and Particle S1ze. . . . . . . . 55

Zinc/Zinc Chloride Condensation. . . . . . . . . . . . . 58

Electrolytic Recovery of Zinc from Zinc Chlorlde . . . . . . . . 58

Zinc Vaporization. . . . . . . . . . . . . . . . . . . 64

Product Quality. . . . . . . . . . . . . . . . . . 65

Seed Preparation . . . . . . . . . . . . . . . . . . 73

D. 50 METRIC TON PER YEAR EXPERIMENTAL FACILITY . . . . . . . . . . . . 75

$50 \mathrm{MT} /$ Year Si Facility Design. . . . . . . . . . . . . . . 76

Feed Preparation . . . . . . . . . . . . . . . . 78

Reaction and Recovery. . . . . . . . . . . . . . . 84

Waste Treatment. . . . . . . . . . . . . . . . . . 85

Fluidized-Bed Reactor. . . . . . . . . . . . . . . 89

Zinc Vaporizer . . . . . . . . . . . . . . . . . . . . 91

Zinc/Zinc Chloride Condenser . . . . . . . . . . . . . 91

Electrolytic Cell. . . . . . . . . . . . . . . . . 94

Plant Layout . . . . . . . . . . . . . . . . . . 96

Cost of Experimental Facility. . . . . . . . . . . . . . . . 98

E. ECONOMIC ANALYSIS OF SILICON PRODUCTION AT THE
$1000 \mathrm{MT} /$ YEAR LEVEL . . . . . . . . . . . . . . . . . . . . . 99

Energy Payback . . . . . . . . . . . . . . . . . . 108

F. CONCLUSION . . . . . . . . . . . . . . . . . . . . 113

REFERENCES . . . . . . . . . . . . . . . . . . . . . . . 114 
Table 1. Mater1als Cost, January, 1975. . . . . . . . . . . . 9

Table 2. Major Equipment Cost, Process A, $24 \mathrm{~kg} /$ hour Un1t . . . . 15

Table 3. Materlals and Energy Costs, Process A. . . . . ..... 16

Table 4. Manpower Unit Breakdown and Cost, Process A, $1000 \mathrm{MT} /$ Year S1licon . . . ............ 16

Table 5. Fixed Capital Investment, $1000 \mathrm{MT} /$ Year S111con ....... 25

Table 6. Product Costs. . . . . . . . . . . . . . . . 26

Table 7. Estimated Cost Breakdown, Processes A Through F, Dollars per kg Silicon................. 27

Table 8. Process Energy Cost, kwh/kg Silicon. . . . . . . . . . . 31

Table 9. Data on the Preparation of Sillcon by the

Fluidized-Bed Hydrogen Reduction of $\mathrm{SiI}_{4}$. . . . . . . . . 33

Table 10. Specifications for DuPont Silicon. . . . . . . . . . 36

Table 11. Thermodynamic Properties of $\mathrm{ZnCl}_{2} \cdot$. . . . . . . . . . . . 39

Table 12. Added Cost (Dollars per $\mathrm{kg}$ Silicon) of Off-Stolchiometry

Operation for Fluidized-Bed Zinc Reduction of Silicon

Tetrachloride at $1200 \mathrm{~K}, 1$ atm . . . . . . . . . . . . . 43

Table 13. Equilibrium Condensation of Zinc and Zinc Chloride from

By-Product Gas Containing $30.45 \mathrm{~m} / 0 \mathrm{Zn}(\mathrm{g}), 41.85 \mathrm{~m} / \mathrm{o}$

$\mathrm{ZnCl}_{2}(\mathrm{~g}), 15.23 \mathrm{~m} / 0 \mathrm{SiCl}_{4}(\mathrm{~g})$, and $2.47 \mathrm{~m} / 0$ Inert Gas . . . 59

Table 14. Summary of Experimental Electrolysis of $\mathrm{ZnCl}_{2}$ at

$500 \mathrm{C}$ (Selected Data)............... 62

Table 15. History and Projection of $\mathrm{ZnCl}_{2}$ Electrolysis . . . . . . 63

Table 16. Geneology and Disposition of Quality Evaluation Products . . 67

Table 17. Removal of Zinc From Silicon on Fusion in Argon

and Vacuum . . . . . . . . . . . . . . . . 68

Table 18. Comparative Analytical Results, ppww, for Zinc

in Silicon................... . . 69 


\section{LIST OF TABLES (Continued)}

Page

Table 19. Comparative Analyses of Silicon Products, ppmw . . . . . 70

Table 20. Density of Silicon Product . . . . . . . . . . . . . 71

Table 21. Design Parameters - $50 \mathrm{MT} /$ Year Silicon Experimental

Facility . . . . . . . . . . . . . . . 77

Table 22. Materials and Energy Flow Sheet (English Units), $50 \mathrm{MT} /$ Year Gilicon Facility. . . . . . . . . . . . 79

Table 23. $\mathrm{SiCl}_{4}$ Composition. . . . . . . . . . . . . . . . 83

Table 24. List of Equ1pment for the $50 \mathrm{MT} /$ Year Experimental

Facility upon Which the Cost Estimates for a $1000 \mathrm{MT} /$

Year Plant are Based................. 100

Table 25. Equipment Costs (1975 Dollars) by Groups for

$50 \mathrm{MT} /$ Year Experimental Facility and $1000 \mathrm{MT} /$

Year Plant -- Cases I, II, and III . . . . . . . . . 104

Table 26. Manpower Breakdown and Costs... . . . . . . . . . 105

Table 27. 'Materials Cost (1975 Dollars). . . . . . . . . . 106

Table 28. Utilities Cost (1975 Dollars). . . . . . . . . . . 107

Table 29. Fixed Capital Investment . . . . . . . . . . . . . . 109

Table 30. Product Costs. . . . . . . . . . . . . . . . . 110

Table 31. Energy Requirements, kwh/kg S1 . . . . . . . . . . . 112

\section{LIST OF FIGURES}

$\underline{\text { Page }}$

Figure 1. Process A Flow Sheet . . . . . . . . . . . . . . 14

Figure 2. Process B Flow Sheet . . . . . . . . . . . . . . 18

Figure 3. Process C Flow Sheet . . . . . . . . . . . . . . . 19

Figure 4. Process D Flow Sheet . . . . . . . . . . . . . . . 21 


\section{LIST OF FIGURES (Coritinued)}

Page

Flgure 5. Process E Flow Sheet.................... 23

Flgure 6. Process F Flow Sheet................. 24

F1gure' 7. Product Cost Breakdown; Processes A Through F. . . . . . . . 28

F1gure 8. Iodination of S111con Ox1de-Carbon M1xtures. ........ 35

Figure 9. Conversion Efficlency; $2 \mathrm{Zn}+\mathrm{SICl}_{4}=2 \mathrm{ZnCl}_{2}+\mathrm{S1}$, 1 atm. . . . . . . . . . . . . . . . . . 38

Figure 10. Efficlency Versus Dilution of $\mathrm{SICl}_{4}$ with Inert Gas (0) and Hydrogen (x), 1 atm. . . . . . . . . . . . . . 41

Figure 11. Efficiency Versus Stoichlometry in $Z$ n Reduction of $\mathrm{SICl}_{4}$ (Diluted $1 / 1$ with Inert Gas). . . . . . . . . . 4 42

Figure 12. Schematic of Unit for the Preparation of Silicon by the Zinc Reduction of $\mathrm{SiCl}_{4}$; (a) Solid Zinc Feed;

(b) Vapor Zlnc Feed. ... . . . . . . . . . . . . . 46

Figure 13. Schemat1c Dlagram of Fluldized-Bed Reactor for the Preparation of Silicon by the Zinc (Vapor Feed)

Reduction of $\mathrm{SiCl}_{4}$. . . . . . . . . . . . . . . . 49

Figure 14. Diagram of Round-Bottom Distributor used in Model

Studfes. . . . . . . . . . . . . . . 53

Figure 15. Typical Sequence from Motion Pictures of the

Fluld1zed Bed Mock-Up. . . . . . . . . . . . . . . 54

Figure 16. Schematic Diagram of Experimental Zinc Chloride to Zinc Recovery System as Originally Constituted . . . . . . 61

Figure 17. Comparison of As-Produced Particles Indicating Increased Sphericity with Decreased Seed Content . . . . . 72

Figure 18. Scanning Electron Micrograph of Fractured Particle From Run 36 Showing Absence of Appreciable Porosity In Coating Between Markers . . . . . . . . . . . . 74

Figure 19. Feed Preparation, . . . . . . . . . . . . . 82

F1gure 20. Reaction and Recovery. . . . . . . . . . . . . 86 


\section{LIST OF FIGURES (Continued)}

$\underline{\text { Page }}$

Figure 21. Waste Treatment. . . . . . . . . . . . . . . 88

Figure 22. 6.5" ID Flüidized-Bed Reactor. . . . . . . . . . . . . 90

Figure 23. Zinc Vaporizer . . . . . . . . . . . . . . . . . 92

Figure 24. $\mathrm{Zinc} / \mathrm{ZnCl}_{2}$ Condenser . . . . . . . . . . . . . . . . 93

Figure 25. Electrolytic Cell. . . . . . . . . . . . . . . . . 95

Figure 26. Plan Vlew. . . . . . . . . . . . . . . . . . 97 
FINAI REPORT

Covering the Period October 9, 1975, to July 9, 1978

on

\section{EVALUATION OF SELECTED CHEMICAL PROCESSES}

FOR PRODUCTION OF LOW-COST SILICON

(Phases $I$ and II)

JPL Contract 954339

Silicon Material Task

Low-Cost Solar Array Project

to

JET PROPULSION LABORATORY

CALIFORNIA INSTITUTE OF TECHNOLOGY

from

BATTELLE

Columbus Laboratories

July 9, 1978

\section{ABSTRACT}

The zinc reduction of silicon tetrachloride in a fluidized bed of seed particles to yleld a granular product was studied along with several modifications of the thermal decomposition or hydrogen reduction of silicon tetraiodide. Although all contenders were belleved to be capable of meeting the quality requirements of the LSA Project, it was concluded that only the zinc reduction of the chloride could be made economically feasible at a cost below $\$ 10 / \mathrm{kg}$ silicon (1975 dollars). Accordingly, subsequent effort was IImited to evaluating that process.

A "miniplant", consisting of a 5-cm-dlameter fluidized-bed reactor and associated equipment was used to study the deposition parameters, temperature, reactant composition, seed particle size, bed depth, reactant throughput, and methods of reactant introduction. It was confirmed that the permisstble range of fluldized-bed temperature was 1 imited at the lower 
end by zinc condensation $(918 \mathrm{C})$ and at higher temperatures by rapidly decreasing conversion efficlency. [by 0.1 percent per degree $C$ from 72 percent (thermodynam1c) at 927 for a stolchlometric mixture]. Use of a graded bed temperature (decreased temperature upwards permitted by decreased $z$ inc dew point of the partlally reacted mixture) was shown to increase the conversion efficiency over that obtained in an 1sothermal bed.

Other aspects of the process such as the condensation and fusedsalt electrolysis of the $\mathrm{ZnCl}_{2}$ by-product for recycle of zinc and chlorine were studied to provide information required for design of a $50 \mathrm{MT} /$ year experimental facility, visualized as the next stage in the development: Direct Induction coupling to the bolling zinc was demonstrated as a rellable means of supply1ng the large heat requirement at that point while maintaining control of the rate of vaporization. Both minlplant and full-scale (25 MT/ year) mock-up studies were made of the fluld1zed-bed reactor des1gn to permit a cholce for the two reactors of the $50 \mathrm{MT} /$ year fac1l1ty.

A total of $6.1 \mathrm{~kg}$ of silicon was prepared on semiconductor-grade seed particles for submission to. JPL. However, analyses by spark-source mass spectrograph, neutron activation, and atomic absorption-are not yet definitive in terms of quality for solar cell use.

Design of the $50 \mathrm{MT} /$ year experimental fac1lity was completed with the cooperation of Raphael Katzen Assoclates International, Inc., of CInc1nnat1, Oh10, and Pace Englneers, Inc., of Houston; Texas. On the basis of that design, described in this report, cost estimates were made for silicon production at the $1000 \mathrm{MT} /$ year level. Although the preparation of $\mathrm{SICl}_{4}$ w111 be by-passed by direct purchase at the $50 \mathrm{MT} /$ year level, operation at the $1000 \mathrm{MT} /$ year level contemplates the chlorination of metallurglcal-grade s111con.with the chlorine from electrolysis of the by-product $\mathrm{ZnCl}_{2}$.

Projected s111con costa of $\$ 7.35$ and $\$ 8.71$ per $\mathrm{kg}$ (1975 dollars) for a $1000 \mathrm{MT} /$ year fac1l1ty were obtained, depending upon the number and size of the fluldized-bed reactors and $\mathrm{ZnCl}_{2}$ electrolytic cells used. An energy payback time of 5.9 montho was calculated for the product s111con.

In view of the favorable technical and economic 1ndications obtalned, 1t 18 recommended that construction and operation of the $50 \mathrm{MT} /$ year experimental fac1l1ty be implemented. 


\section{A. INTRODUCTION}

When JPL, under NASA/ERDA' (now DOE), infitiated the Low-Cost Solar Array Project (LSA), Battelle's Columbus Laboratories (BCL) was given the task of evaluating certain silicon production processes as to their potential for meeting the quality and cost goals set by the LSA Project [semiconductorgrade silicon at $\$ 10 / \mathrm{kg}$ in 1985 (1975 dollars)]. The approach proposed by $B C L$ was (1) to study two processes which were known to have yielded semiconductor-grade silicon in commercial operation during the early days of the semiconductor silicon industry, and (2) to evaluate the probable economic effects of potential process improvements.' The two processes were

(1) Zinc reduction of silicon tetrachloride (DuPont)

(2) Thermal decomposition of silicon tetraiodide (Mallinckrodt).

The first was a batch process, carried out at atmospheric pressure in an open tube to yield a mass of dendrites of non-uniform quality. The second, carried out on a "hot wire" (hot rod) reactor similar to the Siemens reactor now used in the present trichlorosilane reduction process by most silicon producers, was energy intensive.

The major improvements considered were to substitute fluidized beds for the open-tube and hot-rod reactors and to apply hydrogen reduction In varlous forms to the lodide process in place of low-pressure thermal decomposition. Flow sheets were drawn for the various process options, major equipment 1tems were identified and sized, and conventional costestimate procedures used to arrive at production costs, with the objective of choosing the most promising process for further development and eventual pllot plant operation contingent upon continued demonstration of potential. This final report, covering the 2.5 years of profect work, is divided Into four main sections, relating to

(1) Evaluation of candidate processes

(2) Experimental development of the zinc reduction of silicon tetrachloride in a fluidized bed of seed particles 
(3) Design of a $50 \mathrm{MT} /$ year experimental facility

(4) Cost estimates for a $1000 \mathrm{MT} /$ year facility. These subjects are discussed in turn. 


\section{B. EVALUATION OF CANDIDATE PROCESSES}

Six candidate processes, i.e., one variation of the zinc reduction process and five of the iodide process, were evaluated for economic feasibility. As detailed in the Second Quarterly Progress Report for this program $(1)^{*}$, certain constraints and opportunities in the zinc reduction process prompted limiting the evaluation to one option, whereas in the case of the iodide process, a number of apparently competitive options were retained.

The probable technical feasibility of each of the six evaluated processes was established either by prior knowledge or by experimental verification as part of this program. The experimental work associated with the zinc reduction process will be covered in Section $C$ of this report, whereas that associated with the variations of the iodide process will be reported in this section.

The six processes evaluated may be described briefly as follows:

Proccss A - Preparacton of $\mathrm{SiCl}_{4}$ by chlorination of $\mathrm{SiO}_{2} /$ carbon mixtures, zinc reduction of $\mathrm{SiCl}_{4}$ in a fluidized bed of seed particles, and recycle of the zinc and chlorine by electrolysis of the by-product zinc chloride

Process B - Preparation of $\mathrm{SiI}_{4}$ by iodination of the metallurgical-grade silicon produced from $\mathrm{SiO}_{2}+$ carbon, thermal dissociation of $\mathrm{S} \mathrm{I}_{4}$ in a "hot-wire" reactor at low pressure, and recycle of $\mathrm{I}_{2}$ and unreacted $\mathrm{SiI}_{4}$

Process C - Same as (B) except for direct iodination of $\mathrm{S}_{2} \mathrm{O}_{2}$ /carbon mixtures instead of metallurglcal-grade silicon to form the $\mathrm{SiI}_{4}$

Process D - Fluidized-bed hydrogen reduction of $\mathrm{SiI}_{4}$. produced by reaction of by-product HI with

* References are given at the end of this report. 
metallurgical-grade silicon produced as

in (B), recycle of unreacted $\mathrm{SiI}_{4}$, separa-

tion of $\mathrm{H}_{2} / \mathrm{HI}$ by low-temperature condensa-

tion, and recycle of $\mathrm{H}_{2}$ and $\mathrm{HI}$

Process E - Same as (D) except for scrubbing of the

by-product HI from HI-hydrogen off-gas,

followed by wet processing (chlorination of HI

+ dryling of molten lodine under concentrated

silfuric arid), and recycling the lodine and

dried hydrogen (lodination with $I_{2}$ instead

of $\mathrm{HI}$ )

Process $F$ - Same as (D) except $\mathrm{H}_{2} / \mathrm{HI}$ by-product is

recirculated to the iodination step after removal

of unreacted $\mathrm{SiI}_{4}$ but without $\mathrm{H}_{2} / \mathrm{HI}$ separation.

Other alternatives were omitted from the detailed evaluation for a variety of reasons. (I)

A word is in order regarding the potential advantages and disadvantages of the various process options which justifled their choice for economic evaluation.

(1) The fluidized-bed deposition reactor has the advantage of providing a large surface for heterogeneous reaction and hence a high rate of production per unit reactor volume. Facllitated handling of the granular silicon product is another advantage. A disadvantage is that in the lodide process, excess hydrogen is required for reasonable efficiency. Operation of a shallow fluidized bed under reduced pressure is possible, but considered to be economically impractical for that application.

(2) Direct halogenation of $\mathrm{S}_{2}+$ carbon mixtures in place of metallurgical-grade silicon offers the possible economy of avolding that arc-furnace processing. The advantage is clear for the 


\begin{abstract}
preparation of $\mathrm{SiCl}_{4}$ (Process $\mathrm{A}$ ), as the chlorination efficlency is high and the technique has been used commerclally*, but the advantage is less pronounced for the lodide processes where the halogenation efficlency is lower and the loss (and cost of recycle) of costly lodine by entralnment in the $\mathrm{CO}$ by-product, or in the $\mathrm{S1O}_{2} / \mathrm{C}$ ash residue may become a slgnificant cost factor.
\end{abstract}

\title{
Cholce of Process Scale
}

For purposes of economic evaluation, it was assumed that the overall requirement of $3000 \mathrm{MT} /$ year of silicon would be produced at three sites with a capac1ty of $1000 \mathrm{MT} /$ year each. Th1s. production is conveniently handled in the case of Process $A$ with $s 1 x$ fluldized-bed $z$ inc reduction reactors, 15 inches In dlameter, each produclng $24 \mathrm{~kg} / \mathrm{hr}$ of s1l1con (80 percent on stream) as estimated from related experlence. Although the entire plant production might be handled by a single 37-inch-diameter reactor in the case of this mildly exotherm1c reaction, strongly endothermlc reactions, such as the hydrogen reduction of $\mathrm{S}_{1} I_{4}$, Impose restrictions on the dlameter of the fluldized-bed reactor where the endothermic heat requirement is supplied through the wall (even after taking advantage of maximum permissible preheating). For thịs reason, 1t seemed expedient to $11 \mathrm{mlt}$ the size of the fluidized-bed reactor to 15 Inches in dlameter and to proceed from that as a reference. Additional economies from reactor scale-up may be consldered later.

\section{Approach to Economic Evaluation}

The economlc evaluation of Processes A through F Involved the following steps:

However, most' technical-grade S1C14 is currently made in the U.S. by chlorination of Acheson-process silicon carblde for convenience. 
(1) Determination of feasible pressure/temperature/ composition ranges for operation of the candidate processes from thermodynamic data $(2,3,4)$ by means of Battelle's EQUICA free-energyminimization computer program and experimental verifications

(2) Drafting of mass flow and energy flow sheets for the candidate processes, showing the major. process functions and the enthalpy changes involved at each step

(3) Sizing of the major 1tems of equipment necessary for each process $\mathrm{gtep}$ in the light of gross sectional area requirements dictated by gas flow for the mass transfer equipment, and the heat transfer area requirements dictated by the enthalpy changes for each heat transfer unit

(4) Estimation of the cost of the large items of equipment and conversion of the total to a fixed capltal investment in accordance with standard texts on chemical engineering estimation $(5,6,7)$ and with prinr experience at $\mathrm{BCL}$

(5) Determination of the net process energy requirements based on the energy flow diagram with appropriate assumptions concerning process heat exchange, dissipating waste heat, and energy loss

(6) Determination of materials costs based on chemical market prices and mass flow requirements with appropriate assumptions relative to materials utilization efficlency

(7) Estimation of direct labor costs by visualizing the man-hour requirements for the various operations involved in each process 
(8) Conversion of the fixed capital investment, manpower, materials, and utilities costs to estimated product costs in accordance with standard texts on chemical engineering cost estimation $(5,6,7)$.

All costs are for January of 1975, as obtained directly from the records for that period, : or as extrapolated from prior cost estimates by means of published cost indices. (8)

Table 1 gives the January, 1975, materials costs used in the calculations, together with the sources of information.

TABLE 1. MATERIALS COSTS, JANUARY, 1975

\begin{tabular}{lccc}
\hline Material & Lot Size & Cost & Reference \\
\hline $\begin{array}{l}\text { Silicon (metallurgical } \\
\text { grade }\end{array}$ & Tonnage & $\$ 1.00 / \mathrm{kg}$ & $(9)$ \\
$\begin{array}{c}\mathrm{SiO}_{2}-99.5 \text { percent } \\
325 \text { mesh }\end{array}$ & Carload & $\$ 0.0125 / 1 \mathrm{~b}$ & $(10)$ \\
Carbon, pet. coke & Tonnage & $\$ 0.01 / 1 \mathrm{~b}$ & $(11)$ \\
Hydrogen & Piped under & $\$ 0.96 / 1 \mathrm{~b}$ & $(12)$ \\
Iodine; crude & fence & $(\$ 0.50 / 100 \mathrm{SCF})$ & $(10)$ \\
Sicl 4, tech. & Drum & $\$ 2.59 / 1 \mathrm{~b}$ & $(10)$ \\
Zinc & Drum & $\$ 0.185 / 1 \mathrm{~b}$ & $(13)$ \\
\hline
\end{tabular}

The values of $\$ 0.03 / \mathrm{kwh}$ used for power cost in the estimates was obtained from a representative of the Columbus and Southern ohio Electric Company, Columbus, Ohio, as typical for most areas of the United States except those served by hydroelectric power. 
Although 1t was recognized that utllitles other than electrical. would be required, these requirements would be small relative to electrical and to simplify the analysis were not estimated. All process heat was assumed to be electrical. Fifty percent of the exothermic heat was assumed to be recoverable and a 10 percent loss was added to the net endothermic heat requirement to arrive at the total.

The labor rates employed for manpower cost estimates were $\$ 6.60 /$ hour for sk1lled operators and $\$ 4.60 /$ hour for unskilled operators.

The cost of recovering lodine from lodine and lodide wastes of $\$ 0.20 /$ pound was estimated from prior experience at BCL with a large lodide process titanium pllot plant (14) and conflrmed as belng consistent with Industrial experiençe(15).

Any Interest cost on the "capital Investment" in the Initlal Inventory of lodine in Processes $B$ through $F$ would eventually be offset by the Increased value of the upgraded lodine.

Except for the cost of refrlgeration units which were obtalned by quotation, the costs of equipment, once sized, were taken from References 5 . and 6 or, in the case of fluldized-bed reactors, halogenation furnaces, a scraper-condensers, and a centrifugal compressor for lodine/S1I 4 , were based on $B C L$ experfence with similar units.

The following simplifylng assumptions were made:

(1) Rather than to cost out the equipment and processing for $\mathrm{S}_{1 \mathrm{Cl}_{4}}$ production from $\mathrm{Cl}_{2}$, $\mathrm{S}_{2} \mathrm{O}_{2}$, and carbon, that cost and others assoclated with $\mathrm{S}_{14} \mathrm{Cl}_{4}$ production were entered as a materials cost for all of the $\mathrm{S} \mathrm{Cl}_{4}$ used, but with a 20 percent cred1t for on-s1te production. Metallurg1cal-grade silicon from $\mathrm{S}_{2} \mathrm{O}_{2}$ + carbon was s1m1larly 1ntroduced, but at cost.

(2) The permissible volumetric throughput of fluld1zed-bed reactors and lodination reactors was assumed to vary approximately inversely as the square root of the average molecular 
weight, 1.e., approximately inversely as the average viscosity.

(3) Common heat transfer coefficients were assumed:

(a) 70: BTU hr-1 $\mathrm{ft}^{-2} \mathrm{~F}^{-1^{*}}$ for gasses high in $\mathrm{H}_{2}$

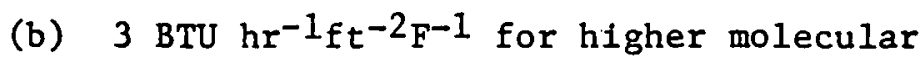
weight gases

(c) $3 \mathrm{BTU} \mathrm{hr}-1 \mathrm{ft}^{-2} \mathrm{~F}^{-1}$ for high molecular vapors condenising to solids in a scraper condenser

(d) $30 \mathrm{BTU} \mathrm{hr} \mathrm{ht}^{-1} \mathrm{~F}^{-1}$ for high molecular weight material being vaporized from its liquid.

Having these values and an estimated available $\Delta T$ for each heat-transfer step, the heat-transfer areas required were estimated.

(4) A 20-plate distillation column having an HETP of 1 foot per plate at unit reflux was assumed to be adequate for the purification of $\mathrm{SiCl}_{4}$ and $\mathrm{SiI}_{4} / I_{2}$, taking a center cut of 90 percent (5 percent tops, 5 percent bottoms): The permissible bo11-up rate, well short of flooding, was based. on BCL experience (14).

(5) The flow charts to be presented in the following pages for the six candidate processes were simplified by the deletion of minor specles such as $\mathrm{S}_{\mathrm{C}} \mathrm{Cl}_{2}(\mathrm{~g}), \mathrm{SII}_{2}(\mathrm{~g}), \mathrm{SiH}_{2} \mathrm{I}_{2}(\mathrm{~g}, \ell), \mathrm{S}_{\mathrm{HHI}}(\mathrm{g}, \ell)$, and monatomic lodine. $\mathrm{SICl}_{2}$ and $\mathrm{SII}_{2}$ would be expected to back react with $\mathrm{ZnCl}_{2}$ or $\mathrm{HI}, \mathrm{I}_{2}$, respectively, on cooling. $\mathrm{SiH}_{2} \mathrm{I}_{2}$ and $\mathrm{S}_{1 H I_{3}}$ were assumed to behave as $\mathrm{SiI}_{4}$ for the purpose of the

* In retrospect and on further study of heat transfer to hydrogen, this value is concluded to be too high, attalnable only at Reynolds numbers for flow above 10,000 , 1.e., above the flow rates that would be used. The net effect of using a lower value, e.g., $h=20$, would be to increase the required size of the heat transfer equipment in Processes $C$ through $F$ and hence the capital costs and product costs above those calculated. 
economic analysis; however, a detailed plant design would have to take the properties of these species into consideration. Although the above minor species were Ignored in the sizlng of equipment, etc., they were used in the thermodynamic calculations of equilibrium conversion efficiency.

(6) The reaction efficiencies and the enthalpies of reactions and phase changes at any given point were taken as those calculated for equilibrium conversion.

\section{Results of Economic Analys 1s}

The six processes for which process cost estimates were made are discussed below in turn. A brief description of the process is given, followed by a flow sheet. In the case of Process A, tables listing ( 1 ) major equipment costs, (2) materials and energy costs, and. (3) manpower costs are included. The reader is referred to Reference (1) for the corresponding tables for Processes B through $\mathrm{F}$.

Tables listing (4) fixed capital investment and (5) product costs for all of the processes are then presented with a discussion of the relative merits of the processes with regard to dollar costs and energy burdens. As noted above, a $24-\mathrm{kg} /$ hour silicon fluidized-bed unit is a convenient size, at least for Process A. Although this is probably not optimum, it was chosen to establish the basic production rate for the plant unit. The $24-\mathrm{kg} /$ hour unit concept was carried over to those processes that do not employ fluidized beds. A $1000 \mathrm{MT} /$ year facility was visualized as consisting of $s i x 24-\mathrm{kg} /$ hour units. No credit was taken for the fact that some equipment, notably tanks, might be common to the six units with a resultant saving. However, this potential economy is probably offset by the fact that to provide for flexibility of operation, a fully designed plant would probably use more tanks than were included here. 
In the process flow diagrams that follow, each block represents a function or plece of major equipment. The conditions of that step are noted in the block; pressure $\cong 1$ atm unless otherwise noted. Also given in each block is the corresponding enthalpy change (t endothermic, - exothermic) in kilocalories per" $1.000 \mathrm{~g}$-mole of silicon product. The compositions (g-moles) of reactants and intermediates are given in parentheses beside arrows corresponding to the process streams.

It will be noted that the listing of major equipment items does not correspond exactly to the process flow diagram in some cases; this was due to changes in thinking during the evalualiun. Revising the process flow sheets did not appear to be justified.

Process A, Fluidized-Bed

Zinc Reduction of $\mathrm{SiCl}_{4}$

Figure 1 is the flow diagram for the zinc reduction of $\mathrm{SiCl}_{4}$ in a fluidized bed of seed particles. Cost estimates are given in Tables 2, 3, and 4.

As noted above, although this process calls for generating the required $\mathrm{SiCl}_{4}$ by treating $\mathrm{SiO}_{2}$ + carbon mixtures with recycled by-product chlorine, the product cost was calculated by treating the $\mathrm{SiCl}_{4}$ as a materials cost with a 20 percent credit for on-site preparation.

It should also be noted that two options for recycling the unreacted $\mathrm{SICl}_{4}$ are shown in Figure 1 . In the economic analysis, this material was recycled to purfication rather than directly to deposition.

By-product $\mathrm{ZnCl}_{2}$ is most conveniently recycled by fused salt electrolysis at $500 \mathrm{C}$, which conserves energy. The cost of the electrolytic cells was based on the experience of Threlfall(16); however, it was later learned that the U.S. Bureau of Mines at Reno, Nevada, has been developing the $\mathrm{ZnCl}_{2}$ electrolysis ${ }^{(17)}$, and that work has been adopted as a guide for future reference.

The constraints that have prompted consideration of this single zinc-reduction process option are discussed in Section $C$ of this report. 


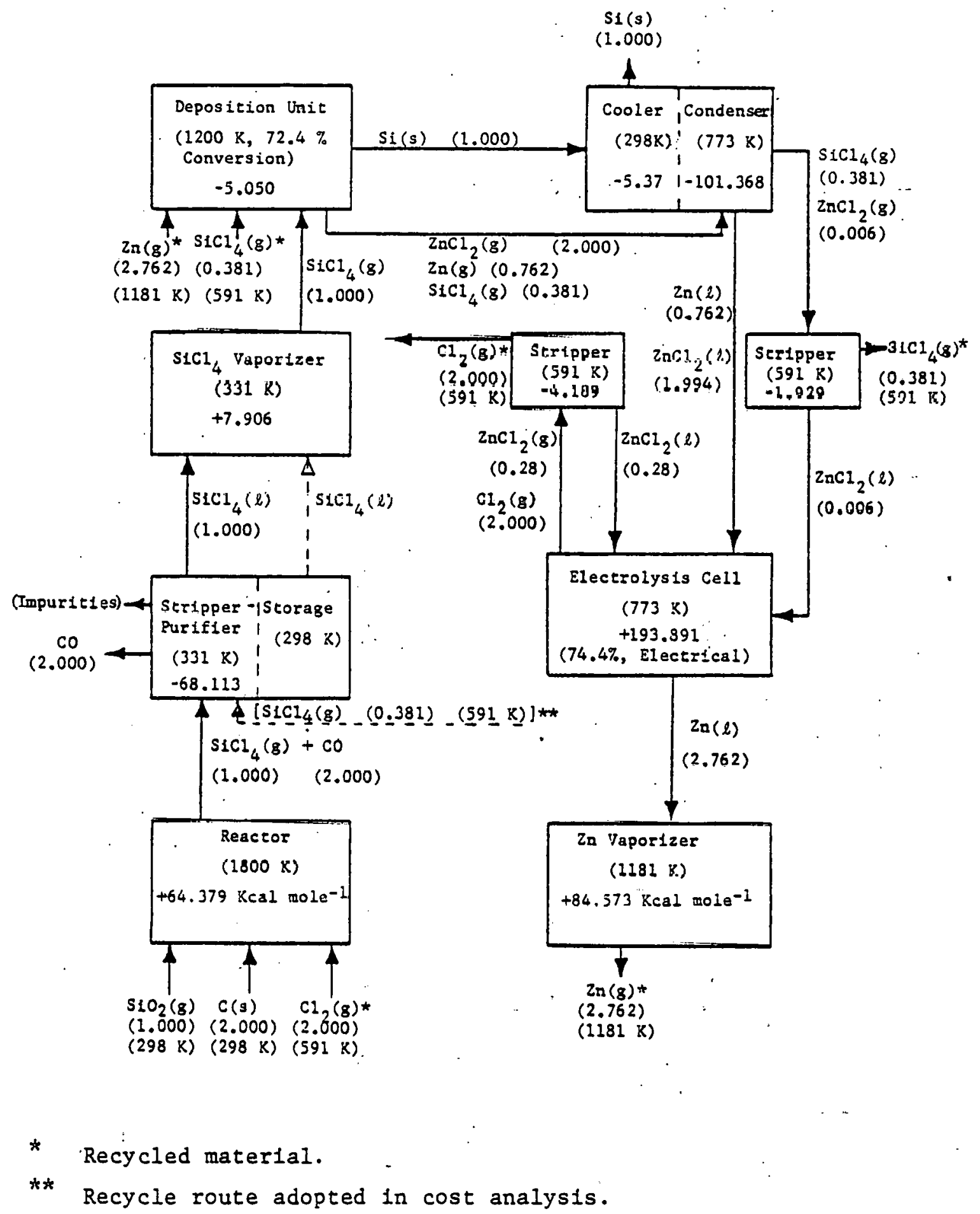

FIGURE 1. PROCESS A FLOW SHEET

Zinc Reduction of Silicon Tetrachloride

$=\quad-14$ 
TABLE 2. MAJOR EQUTPMENT COST, PROCESS A

$24 \mathrm{~kg} /$ HOUR UNIT

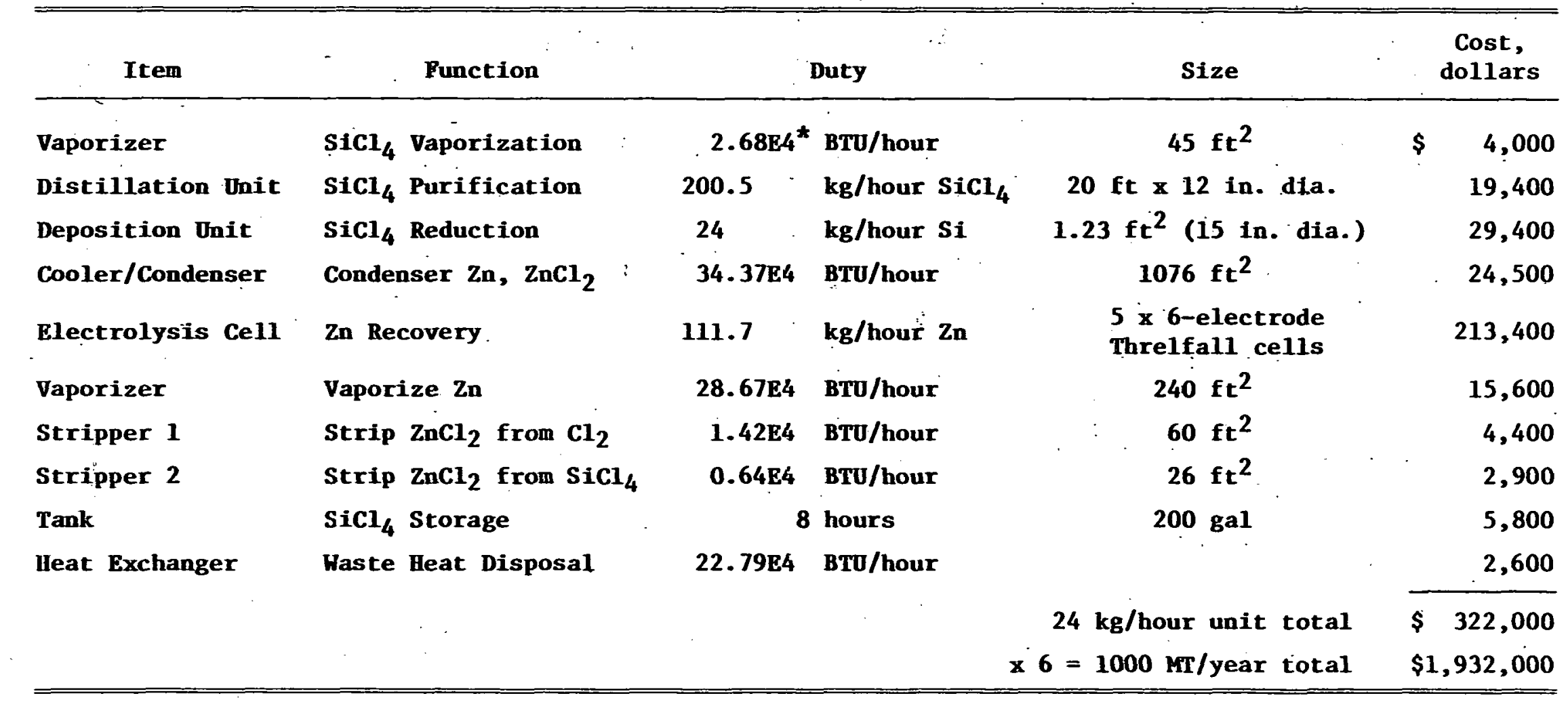

$\star 2.68 \mathrm{E} 4=2.68 \times 10^{4}$ 
TABLE 3. MATERIALS AND ENERGY COSTS, PROCESS A

\begin{tabular}{|c|c|c|}
\hline Item & Corditions & $\begin{array}{l}\text { Cost } \\
\$ / \mathrm{kg} \mathrm{Si}\end{array}$ \\
\hline Zinc & 10 percent loss or cost balanced recovery & $\$ 0.40$ \\
\hline \multirow[t]{2}{*}{$\mathrm{SiCl}_{4}$} & $\begin{array}{l}90 \text { percenc utilization, } 20 \text { percent onsite } \\
\text { manufacturing credit }\end{array}$ & 2.19 \\
\hline & Total, materials & $\$ 2.59$ \\
\hline Elect & 1, 90 percent utilization, $11.17 \mathrm{kwhr} / \mathrm{kg}$ & $\$ 0.335$ \\
\hline
\end{tabular}

TABLE 4. MANPOWER UNIT BREAKDOWN AND COST, PROCESS A $1000 \mathrm{MT} /$ YEAR SILICON

\begin{tabular}{lcc}
\hline \multicolumn{1}{c}{ Untt Operation } & $\begin{array}{c}\text { Number of } \\
\text { Operators }\end{array}$ \\
\hline Deposition & 16 & \\
Zinc Electrolysis & 20 & \\
Distillation & 16 & \\
Raw Material Handling & $8 \quad$ (semi-skilled) \\
Product Handling & $8 \quad$ (semi-skilied) \\
& $\overline{68}$ (divided into \\
& & $\begin{array}{c}\text { (dour crews) } \\
\end{array}$
\end{tabular}

Equivalent manpower hourly rate of $\$ 416.80$

Operating Labor Cost/year $=\$ 892,790$

( $\$ 416.80 /$ hour $\times 2142$ hours/year)

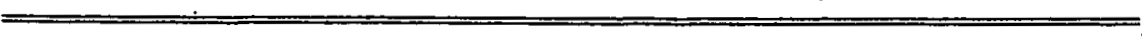

* Fifty-two skilled operators at $\$ 6.60 /$ hour; 16 semi-skilled operators at $\$ 4.60 /$ hour. 
Process B, Thermal Decomposition of $\mathrm{SiI}_{4}$ Product from Metallurgical-

Grade Silicon

Figure 2 covers Process $\dot{B}$, the thermal decomposition of $\mathrm{SiI}_{4}$ made from metallurgical-grade silicon. This is the conventional fodide silicon process as investigated by $\mathrm{BCL}(14)$ and carried to the prototype stage by Mallinckrodt, Inc. A compressor has been added to the process to permit condensation of $\mathrm{I}_{2} / \mathrm{SiI}_{4}$ for recycle as liquid rather than solid.

It will be noted that the major penalty on this process is the high cost of radiant energy lost from the "filaments" In the deposition step. In arriving at a projected energy loss for this factor, $25 \mathrm{kwhr} \mathrm{kg}^{-1}$ estimated process energy was subtracted from the $375 \mathrm{kwh} \mathrm{kg}^{-1}$ total reported (9) to be characteristic of the present Siemens Process production of silicon from trichlorosilane. It was then assumed that 45 percent could be saved by suitable external heat reflection $\left[\left(\frac{900 \mathrm{~K}}{1300 \mathrm{~K}}\right)^{4}=23\right.$ percent $]$ and by mutual heat reflection (22 percent) from a "forest" of filaments such as used in a titanium pilot plant deposition unit at $B C L(14)$. Despite this projected saving, Process $B$ would still require $190 \mathrm{kwh} \mathrm{kg}^{-1}$ solely to maintain the deposition surface temperature.

Process $\mathrm{C}$, Thermal Decomposition of $\mathrm{SiI}_{4}$

Produced by Iodination of $\mathrm{SiO}_{2}$-Carbon Mixtures

The thermal decomposition of $\mathrm{SiI}_{4}$ produced by iodination of $\mathrm{SiO}_{2}-$ carbon mixtures 1s shown in Figure 3: This process differs from Process $B$ In the equipment and increased manpower needed to iodinate $\mathrm{SiO}_{2}$-carbon mixtures. In analyzing the economics of this option, it was hoped that the lowered cost of $\mathrm{SiO}_{2}$ and carbon relative to metallurgical-grade silicon would result in a net saving. Unfortunately, the efficiency of the iodination reaction

$$
\mathrm{SiO}_{2}+2 \mathrm{I}_{2}+2 \mathrm{C}=\mathrm{SiI}_{4}+2 \mathrm{CO},
$$

found to be 20 percent at best, is too low to achieve that goal. The large lodine recycle load is defeating. 


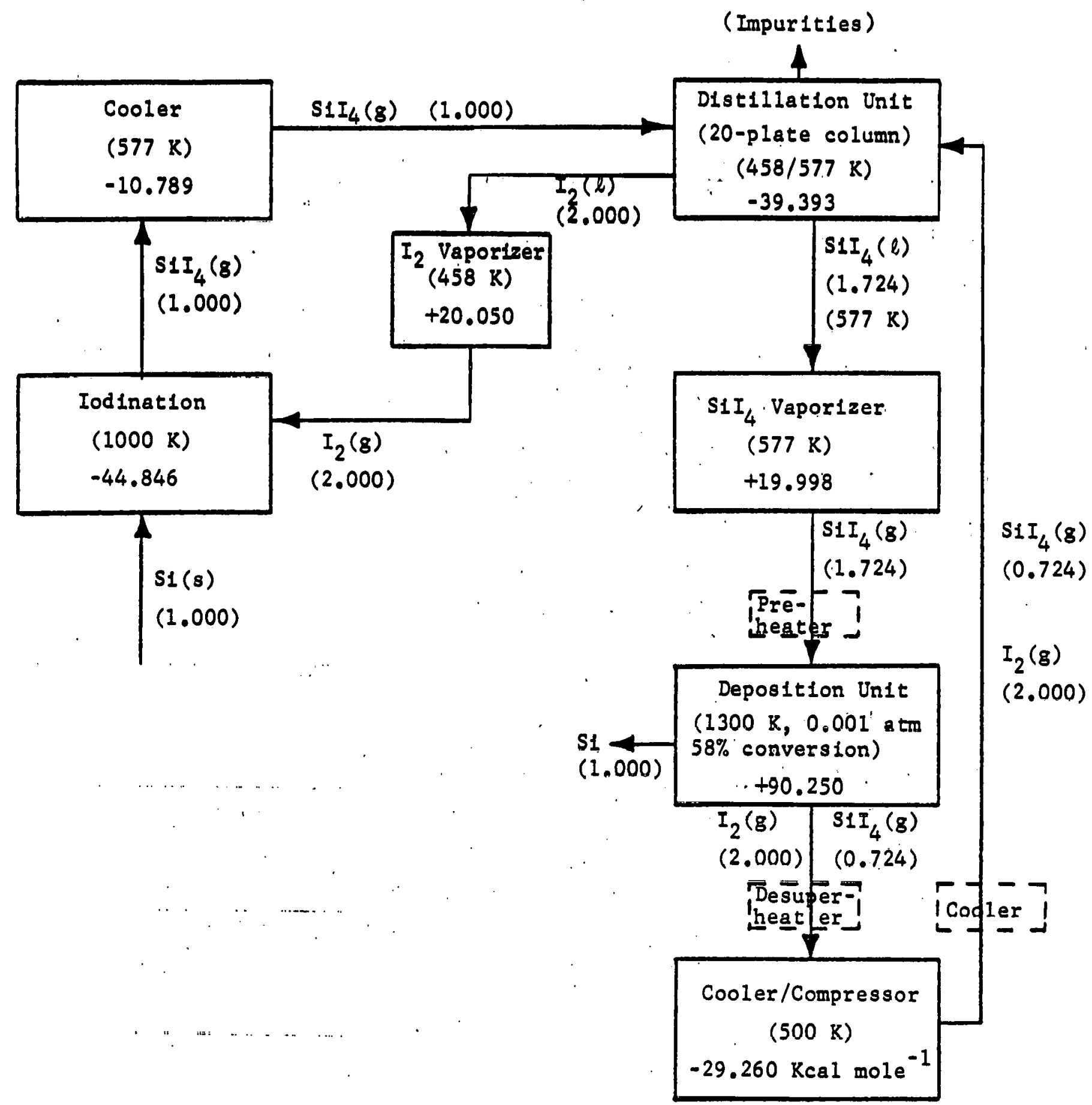

FIGURE 2. PROCESS B FLOW SHEET

Thermal Decomposition of $\mathrm{SlI}_{4}$ Produced

from Metallurgical-Grade Silicon 


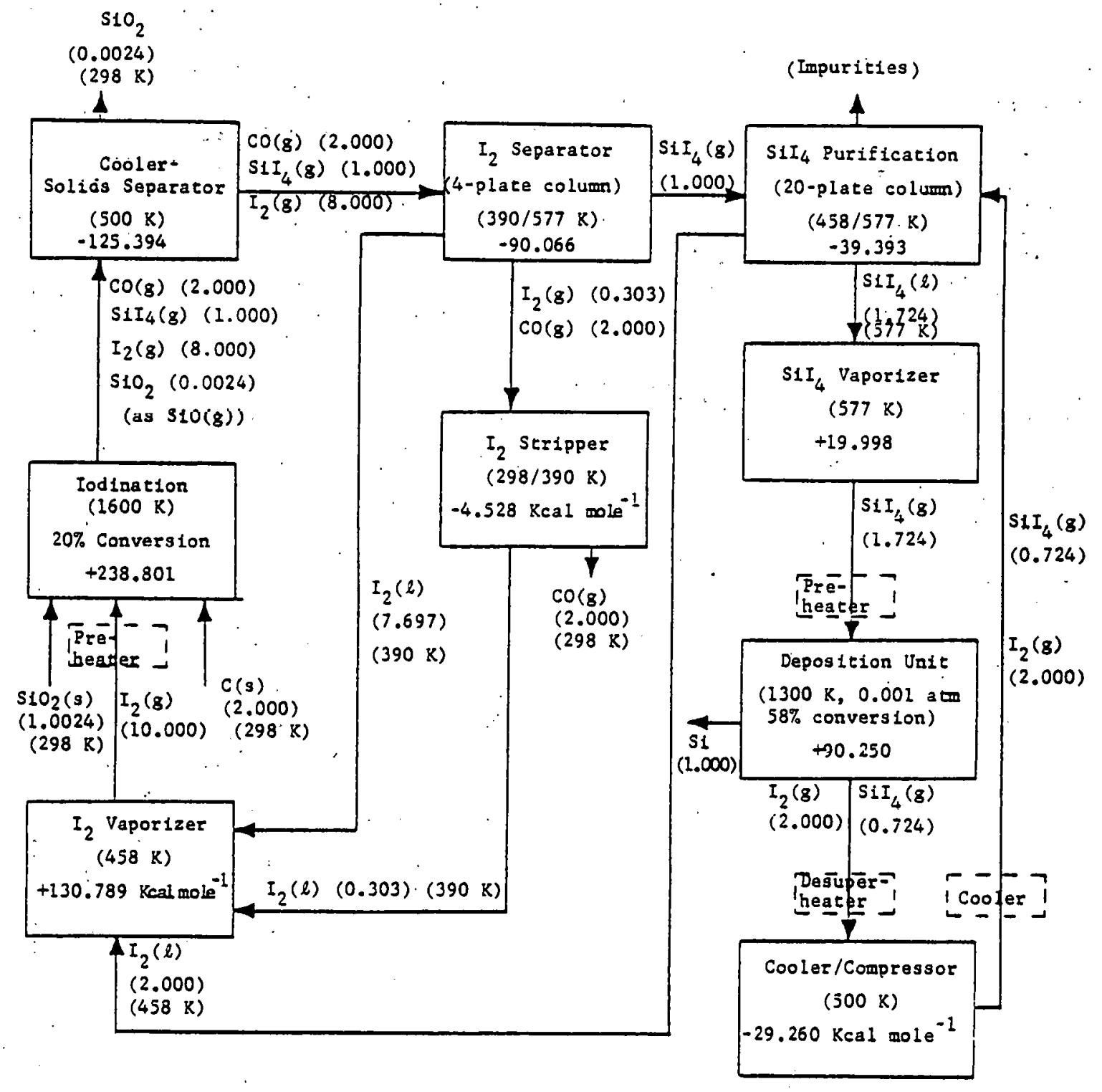

FIGURE 3. PROCESS C FLOW SHEET

Thermal Decomposition of $\mathrm{S}_{4}$ Produced by Iodination of $\mathrm{S}_{10} /$ /Carbon Mixtures 
Experimental and theoretical work on the lodination of $\mathrm{S}_{2} \mathrm{O}_{2}$ mixtures that resulted in the cholce of the 20 percent conversion figure is discussed separately later.

Process $D$, Hydrogen Reduction of $\mathrm{S}_{4}$ In a Fluldized Bed, Dry HI Recycle

An attractive option (Process D, Flgure 4) for the production of silicon from $\mathrm{SiI}_{4}$ is hydrogen reduction of the latter in a fluidired-bcd reactor to avold the large cost of the low pressure deposition cycle and to take advantage of the continuous process potentlal*. The HI by-produce can be recycled by low-temperacure condensallon. Ilowever, this condensatinn is complicated by the high vapor pressure of solid III, $0.46 \mathrm{~atm}$ at the melting point, $-51 \mathrm{C}$. The dew point of $\mathrm{HI}$ in the deposition by-product for the representative condition chosen is $194 \mathrm{~K}(-79 \mathrm{C})$ and to condense out most of the HI at atmospheric pressure requires a scraper condenser operating at, say, $-153 \mathrm{C}$. This mechanical condenser and the associated refrigeration accounts for about half of the capital investment. Pressurizing the $\mathrm{HI}+\mathrm{H}_{2}$ by-product to allow condensation of the HI as a liquid at $3 \mathrm{C}$ above its melting point (i.e., at $-48 \mathrm{C}$ ) alleviates the problem only slightly. Compression to 10 atm permits condensation of only 37 percent of the HI, and a pressure of 60 alm is necessary for 90 percent cnndensation. The option of operating this section of the plant at high pressures is discussed below in the comparison of process costs.

The other major cost items are the scraper condenser, necessary to remove $\mathrm{SiI}_{4}$ as condensed solid at two points, and the fluidized-bed reactor(s) which, because of the lower efficiency and large volumes of excess hydrogen, require seven times the cross sectional area required in Process $A$. Operating manpower costs are correspondingly higher.

Elimination of the large radiant energy loss of the "hot-wire" reactors is another advantage. 


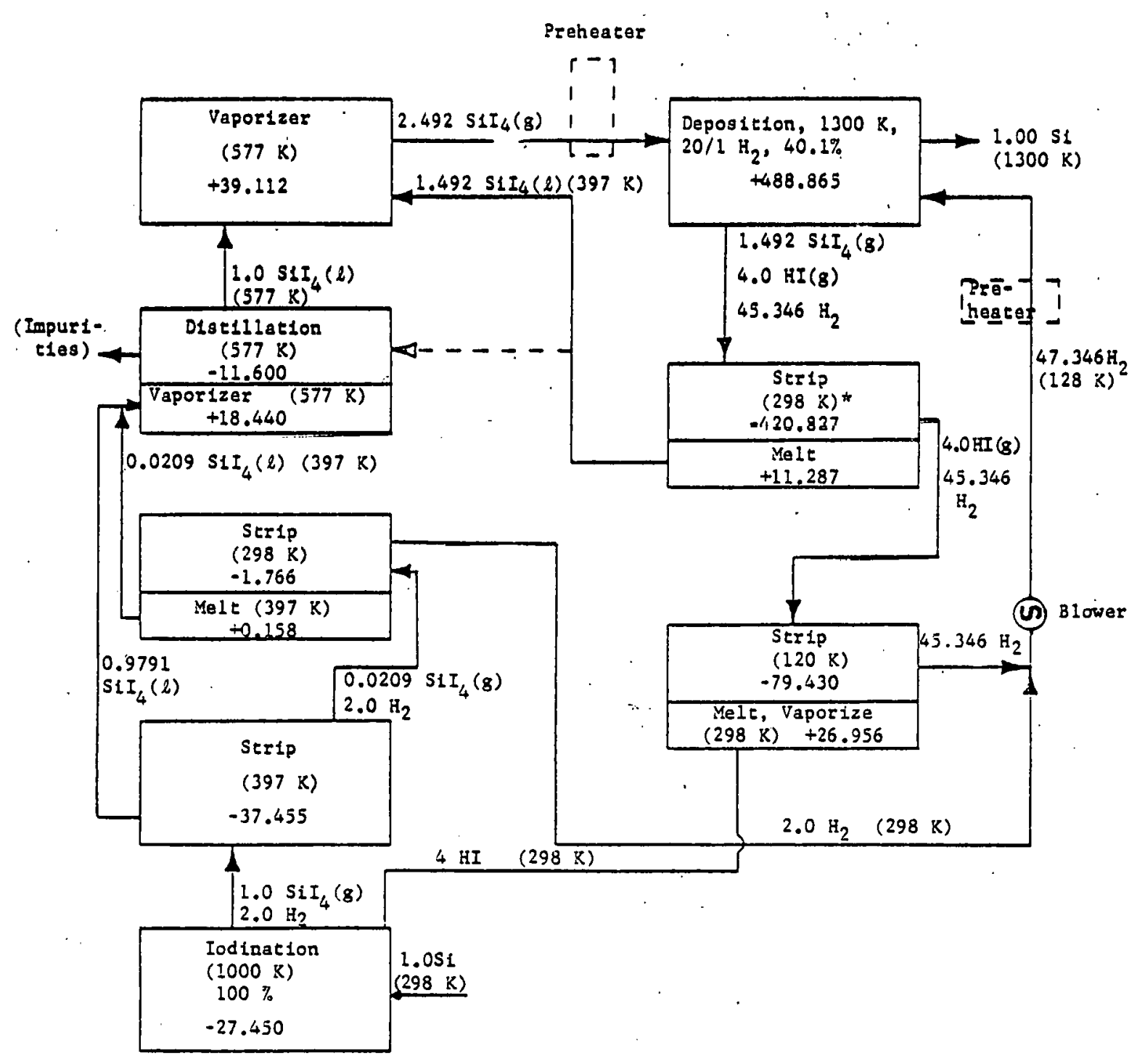

* Probably broken into 2 stages, ist stripping out 0.994 moles $\mathrm{SiI}_{4}(\mathrm{l})$ at $397 \mathrm{~K}$, 2nd, residual $0.498 \mathrm{SiI}_{4}(\mathrm{~s})$ moles at $298 \mathrm{~K}$.

FIGURE 4. PROCESS D FLOW SHEET

Fluidized-Bed Hydrogen Reduction of $\mathrm{SiI}_{4}$, Dry HI Recycle 
Process E, Fluidized-Bed Hydrogen Reduction

of $\mathrm{SiI}_{4}$ with Wet-Process Iodine Recycle

As the condensation of the reaction product HI was such a problem in Process $D$, the possibility of scrubbing the HI from the $\mathrm{H}_{2}$ process gas and recovering the lodine by wet chemistry was explored in Process E, as described in Figure 5.

Process F, Fluidized-Bed Hydrogen Reduction of $\mathrm{SiI}_{4}$ with Recirculation of Unseparated $\mathrm{HI} / \mathrm{H}_{2}$

Although the wet-process iodine recovery in Process $E$ avoids some of the high capital investment for dry HI recycle in Process $D$, this saving is more than offset by the $\$ 0.20 /$ pound cost of recovering iodine by the wet process. It thus becomes of interest to examine the cost of a process in which the $\mathrm{HI}$ and $\mathrm{H}_{2}$ are not separated and the less efficient lodination of silicon and deposition of silicon from the purified $\mathrm{S}_{4} \mathrm{I}_{4}$ are accepted. Since the iodination and decomposition efficiencies are interdependent, it was necessary to calculate the process stream compositions by successive approximations which ylelded the results shown in Figure 6. Owing to the lower efficiencies and lower concentrations of reactants in the feed streams, the sizes of the processing units are increased.

Processes A Through F Cost Summary

The fixed capital Investments for Processes A through F are given in Table 5 and the product cost calculations are given in Table 6 .

Table 7 and Figure 7 summarize the process cost estimates in terms of materials, utilities, capital-related, labor-related, and "other" costs. Process $\mathrm{A}$, the zinc reduction of $\mathrm{SICl}_{4}$ shows lowest cost in all categorles. "Improvements" (Processes C through F) on the bastc "hot-wire" Iod1de process (B') led to higher costs as economies in one area were more than offset by increased costs in others. 


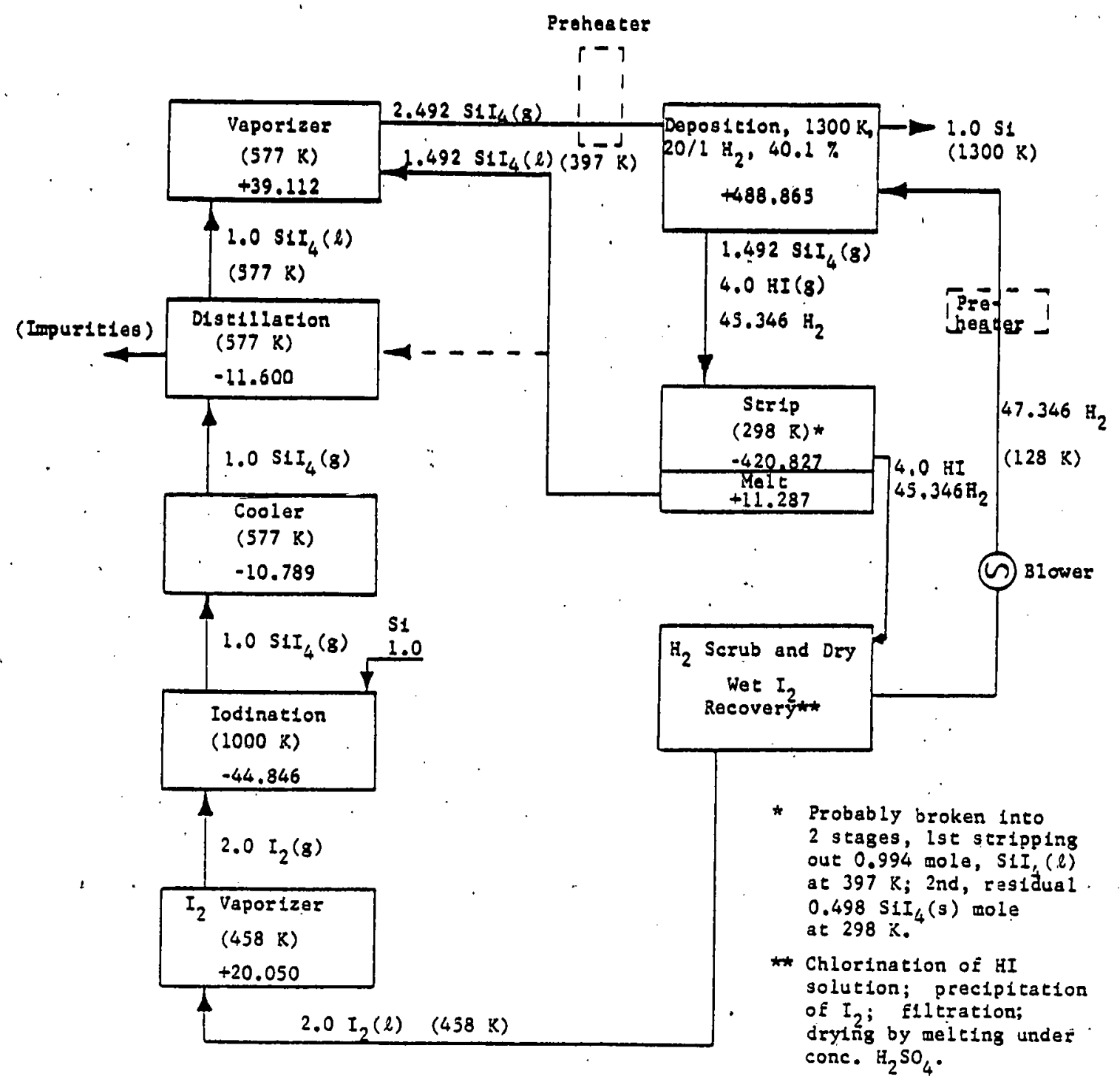

FIGURE 5. PROCESS E FLOW SHEET

Fluidized-Bed Hydrogen Reduction of $\mathrm{SiI}_{4}$, Wet-Process $I_{2}$ Recycle 


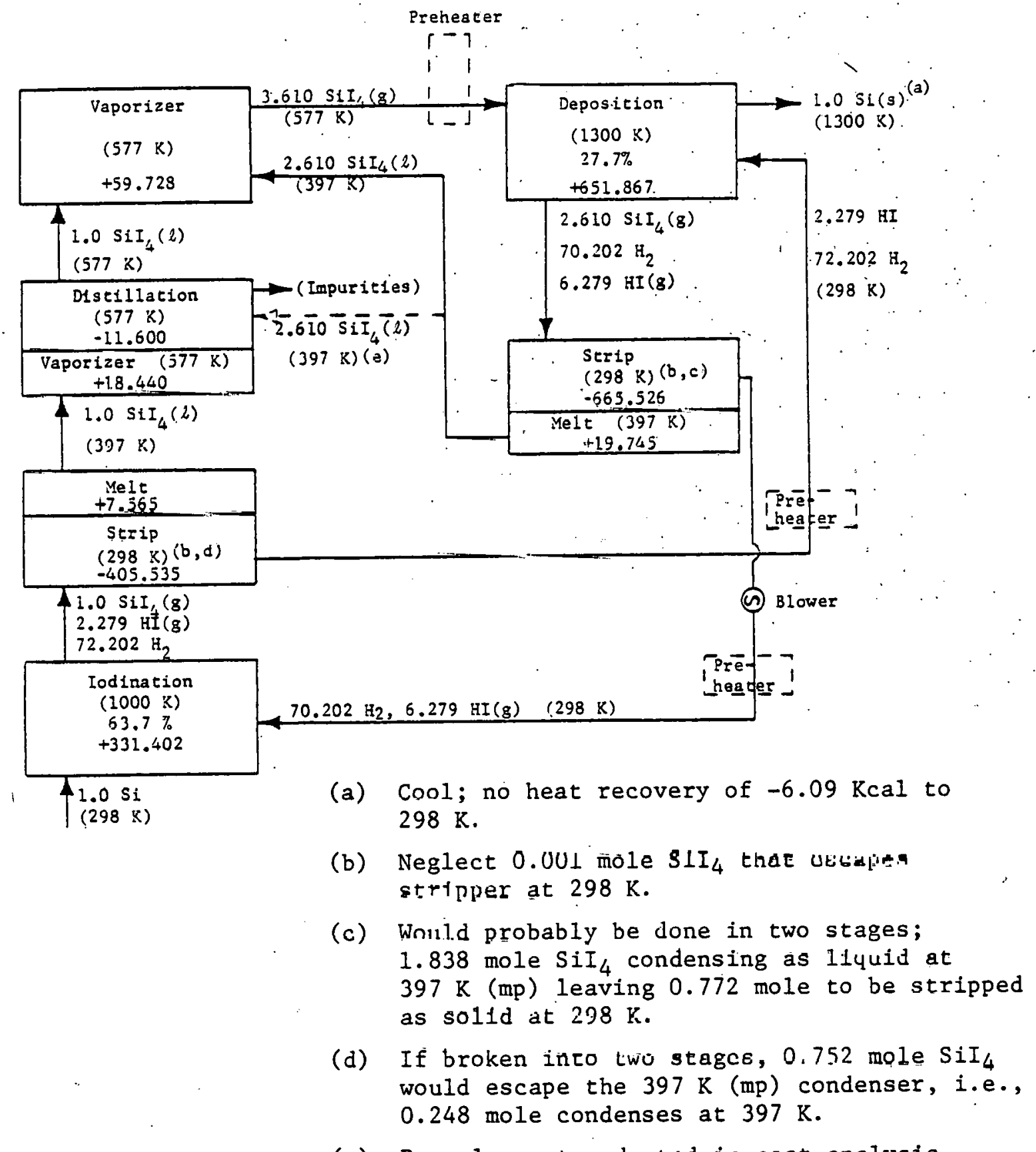

(e) Recycle route adopted in cost analysis.

FIGURE 6. PROCESS F FLOW SHEET

Fluidized-Bed Hydrogen Reduction of $\mathrm{SiI}_{4}$ With

Recirculation of Unseparated $\mathrm{H}_{2} / \mathrm{HI}$ 
TABLE 5. FIXED CAPITAL INVESTMENT 1000 MT/YEAR SILICON

\begin{tabular}{|c|c|c|c|c|c|c|c|c|c|}
\hline $\cos t$ Item & & $\therefore$ & & Pocess A & Process B & Prócess: C & Prucess'd & Process E & Process F \\
\hline \multicolumn{10}{|l|}{ Direct Cost (D) } \\
\hline Purclased equipment (E) & & $\therefore$ & & $\$ 1,932,000$ & $\$ 4,488,000$ & $\$ 6,180,1000$ & $\$ 11,808,000$ & $\$ 5,166,000$ & $\$ 11,622,000$ \\
\hline Inscallation of $B$ & & 40 percent of $E$ & & 772,800 & $2,019,600^{*}$ & $2 ; 781,000^{\star *}$ & $4.723,000$ & $2,066,400$ & $4,684,800$ \\
\hline Instrumentatfun (Insta1led) & & 25 percent of $E$ & & 483,000 & $1,122,000$ & $1,545,000$ & $2,952,000$ & $1,291,500$ & $2,905,500$ \\
\hline Piplng (Instailed) & & 6in percent of. & & $1,159,200$ & $2,692,800$ & $3,708,000$ & $7,084,800$ & $3,099,600$ & $6,973,200$ \\
\hline Electrical (Installed) & & 15 percent of $E$ & & 289.800 & 673,200 & $-\quad 927,000$ & $1,7.71,200$ & 774,200 & $1,743,300$ \\
\hline Bulldings and Services & & 47 percent of $E$ & & $.908,040$ & $2 ; 109,360$ & $2,904,600$ & $5,549,760$ & $2,424,020$ & $5,462,340$ \\
\hline Yard Improvements & & 10 percent of $E$ & & 193,200 & 448,800 & 618,000 & $1,180,800$ & 516.600 & $1,162,200$ \\
\hline Service Pactiftles & & 40 percent of $E$ & & 772,800 & $1,795,200$ & 2,$472 ; 000$ & $4,723,000$ & $2,066,400$ & $4,684,800$ \\
\hline Land & & 6 percent of $E$ & $:$ & 125,920 & 269,280 & 370,800 & 708.480 & 309.960 & 697,320 \\
\hline TOTAL DIKECI COST & & & & $\$ 6,626,760$ & $\$ 15,618,240$ & $\$ 21,506,400$ & $\$ 40,501,440$ & $\$ 17,719,380$ & $\$ 39,863,460$ \\
\hline Indirect cost (I) & & .. & & & & & & & \\
\hline Engineer Ing and Supervision & & 15 percent of $E$ & & $\$ 289,800$ & 673,200 & 927,000 & $\$ 1,771,200$ & 774.900 & $\$ 1,74.3,300$ \\
\hline Construction Expenses & & 14 percent of $E$ & & 270,480 & 628,320 & 865,200 & $1,653,120$ & 723,240 & $1,627,080$ \\
\hline TOTAL D AND I & & & & $\$ 7.187,040^{\circ}$ & $\$ 16,919,760$ & $\$ 23,298,600$ & $\$ 43,925,760$ & $\$ 19,217,520$ & $\$ 43,233,840$ \\
\hline Cuntractor's Fee & & 10 percent of $D$ and & & $\$ 718,680$ & $\$ 1,692,000$ & $\$ 2,329,850$ & $\$ 4,392,600$ & $\$ 1,921,740$ & $\$ 4,323,360$ \\
\hline Cont 1ngency & & 10 percent of $D$ and & I & $\$ 718,680$ & $\$ 1,692,000$ & $\$ 2,329,8.50$ & $\$ 4,392,600$ & $\$ 1,921,740$ & $\$ 4,323,360$ \\
\hline Flxed Capltal Investment, 1000 & Mr/year & & & $\$ 8,624,400$ & $\$ 20,303,760$ & $\$ 27,958,390$ & $\$ 52,710,960$ & $\$ 23,061,000$ & $\$ 51,880,560$ \\
\hline
\end{tabular}

* 45 percent of $\mathrm{E}$. 
TARLE E. PRODUCT COSTS

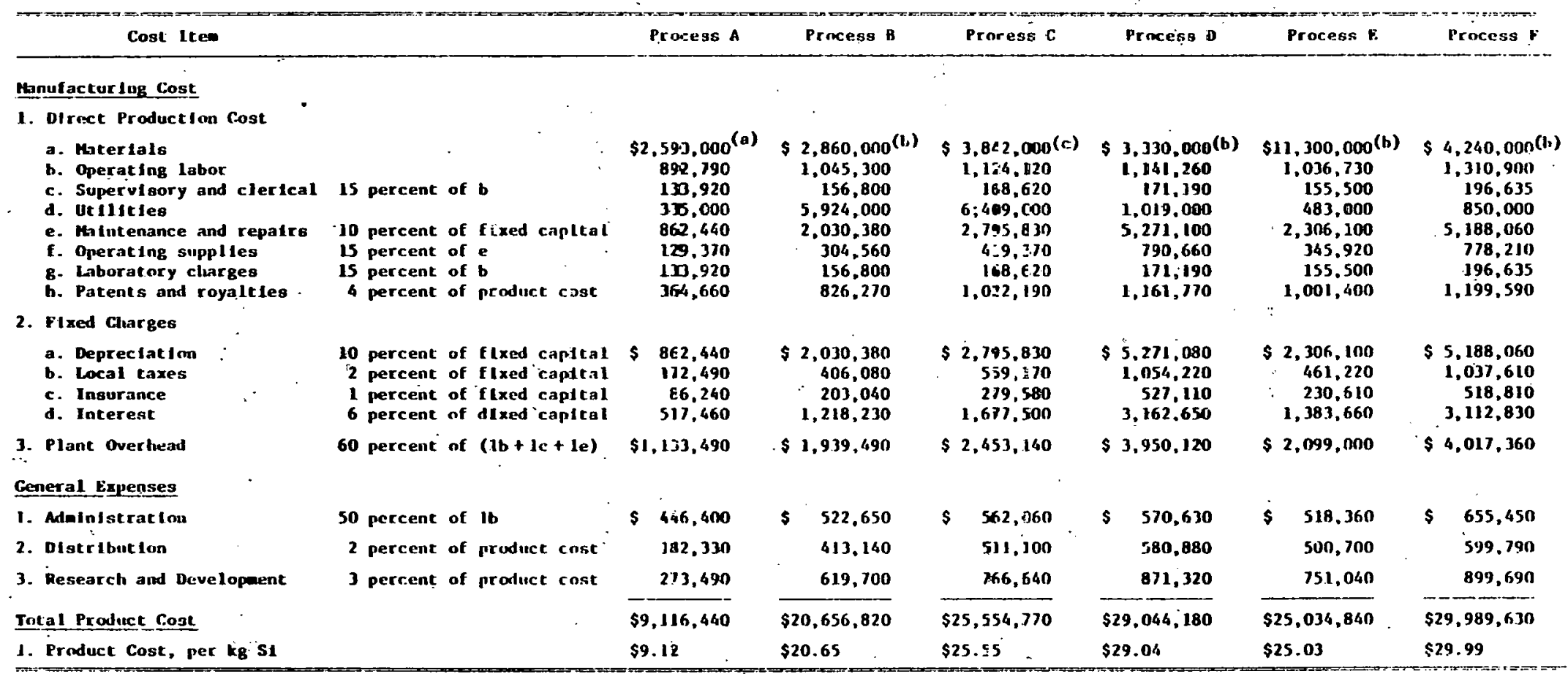

(a) Includes all cost (opera: Ing and copltal Investaent) for sica 4 used.

(b) Includes all cost (operating and capltal lnvestwent) ror the recovery of lodine scrap by the wer process.

(c) Includes all cost (opecaring and capital investment) "For the recovery of scrap and recycled lodine by the vet process. 


\section{TABLE 7: ESTIMATED COST BREAKDOWN, PROCESSES A THROUGH F, DOLLARS PER $\mathrm{kg}$ SILICON}

\begin{tabular}{|c|c|c|c|c|c|c|}
\hline \multirow[b]{2}{*}{ Item } & \multicolumn{6}{|c|}{ Process } \\
\hline & $\bar{A}$ & B & $\mathrm{C}$ & $\bar{D}$ & $\bar{E}$ & $\bar{F}$ \\
\hline Materials & $\$ 2.59$ & $\$ 2.86$ & $\$ 3.84$ & $\$ 3.33$ & $\$ 11.30$ & $\$ 4.24$ \\
\hline Utilities $^{(a)}$ & 0.34 & 5.92 & 6.41 & 1.02 & 0.48 & 0.85 \\
\hline Capital-related ${ }^{(b)}$ & 3.15 & $7: 41$ & 10.20 & 19.24 & 8.42 & 18.94 \\
\hline Labor-related & 2.22 & 2.60 & 2.80 & 2.84 & 2.58 & 3.26 \\
\hline Others $(c)$ & 0.82 & 1.86 & 2.30 & 2.61 & 2.25 & 2.70 \\
\hline$\therefore \ldots$ TOTAL & $\$ 9.12$ & $\$ 20.65$ & $\$ 25.55$ & $\$ 29.04$ & $\$ 25.03$ & $\$ 29.99$ \\
\hline
\end{tabular}

(a) Electrical only, see text.

(b) Includes labor portion of maintenance cost based on capital.

(c) Patents and royalties, 4 percent of total; distribution, 2 percent of total; research and development, 3 percent of total 


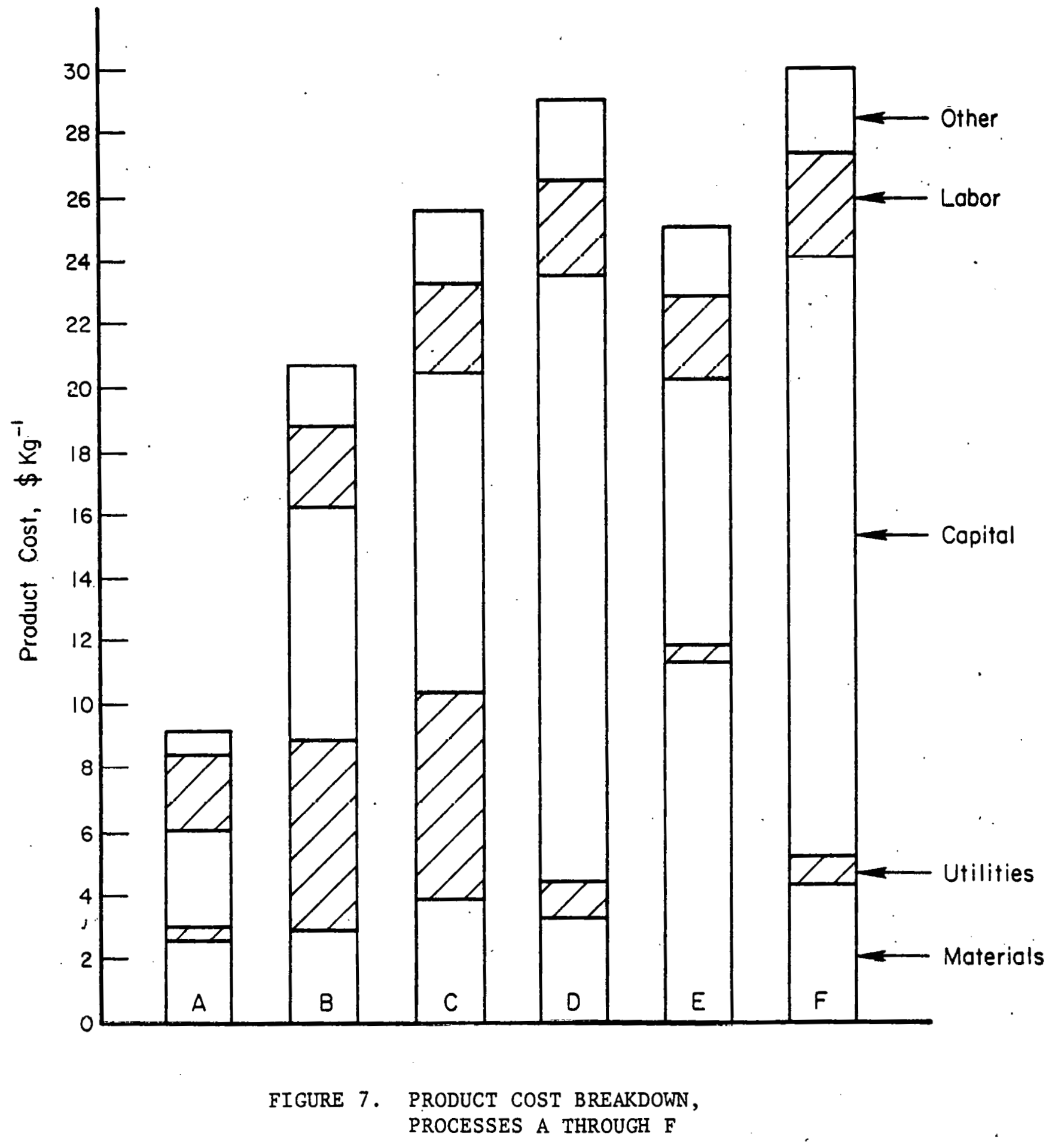


The most promising approach for reducing the cost of the iodide processes would be via optimizing the recycle of the HI by-product of Process $D$ by pressurized condensation, whereby it may well be possible to beat the $\$ 20.65 / \mathrm{kg}$ cost of the "hot wire" process (B). However, Process.D optimized in that way can never be less expensive than Process A, as even if the cost of HI recycle were zero (equivalent to subtracting the wet process recycle cost from the product cost in Process E), the net cost would be $\$ 15.70 / \mathrm{kg}$ of silicon $(\$ 25.03-\$ 9.33)$, which exceeds the $\$ 9.12 / \mathrm{kg}$ cost of Process $A$ by 70 percent.

In making the above cost estimates, it was recognized that a more detalled engineering design of the processes would disclose needs for additional minor items of process equipment thal would result in higher costs, presumably by a small fraction of the major cost items already identified. On the other hand, opportunities for economies should be also recognized which may well offset the cost of added equipment. It should also be pointed out that considerable uncertainty exists in the cost of electrolytic zinc recovery for Process A which will not be fully resolved until a prototype plant is operated. If this cost can be made less than that assumed, a significant decrease in the cost of the product will be obtained because of the appreciable fraction of the total cost represented by the electrolytic zinc recovery operation.

Although some uncertainty exists in the absolute validity of the above cost estimates, their relative values indicate a clear choice of Process A over the iodide process variations. The product cost estimate for Process $A$ which fell below the $\$ 10 / \mathrm{kg}$ LSA target and the short energy payback time (discussed in the next section) gave the incentive for continued development of this zinc reduction process. The decision to proceed with that development was further justified by an independent economic analysis of Process A by Lamar University(18) which led to an estimated product cost of $\$ 9.63 / \mathrm{kg}$. The 22 percent higher capital equipment cost estimate by Lamar was partially offset by a 41 percent lower labor requirement.

Development of the zinc reduction of silicon tetrachloride on seed particles in a fluidized bed to yield a free flowing granular product is discussed in Section $C$ of this report. 


\section{Energy Consumption}

There exists an as yet undetermined limit to the energy consumption that can be tolerated for a process producing silicon for solar cell use. That is, the energy consumed in materials production must be a small fraction of that produced by the cell during its lifetime. Table 8 gives the energy consumption estimated for the candidate Processes A through F. The values shown were obtalned by adding the energy costs of producing or reclaiming certain raw materials to the process energies given in the corresponding tables for the individual processes.

Although it is recognized that some of the process energy may be other than electrical, the calculations are based on units of kwh electrical, since that is the form of energy to be credited to the cell operation as a photovoltaic device.

The last column gives the energy payback time in months for a reference cell:

$0.0254-\mathrm{cm}$ thick producing $0.1 \mathrm{kw} / \mathrm{m}^{2}$ in $1825 \mathrm{hr} / \mathrm{yr}$ operation, allowing for 20 percent loss of silicon during cell manufacture, 1.e., $20.5 \mathrm{kwh} /(\mathrm{mo} \mathrm{Kg})$.

These results show that none of the processes can be ruled out on the basis of energy consumption, although the "hot wire" processes ( $B$ and $C$ ) have high energy burdens which may be prohibittve when cell and array manufacturing energy requirements are added. The zinc reduction of silicon tetrachloride (Process A) Is among the lowest of the others in terms of energy burden with a payback time of only 2.2 months (see revised estlmate, page 108).

Experimental Hydrogen Reduction of $\mathrm{S}_{1} \mathrm{I}_{4}$ :

To confirm the feasibility of the fiuldized-bed hydrogen reduction of SiI4, two experimental runs were made in a 50-m fluidized-bed reactor similar to that to be described In Section $C$ of this report (F1gure 12). The conditions and results for the run wh1ch proceeded without operational problems are given in Table 9. 
TABLE 8. PROCESS ENERGY COST, $\cdot \mathrm{kwh} / \mathrm{kg}$ SILICON

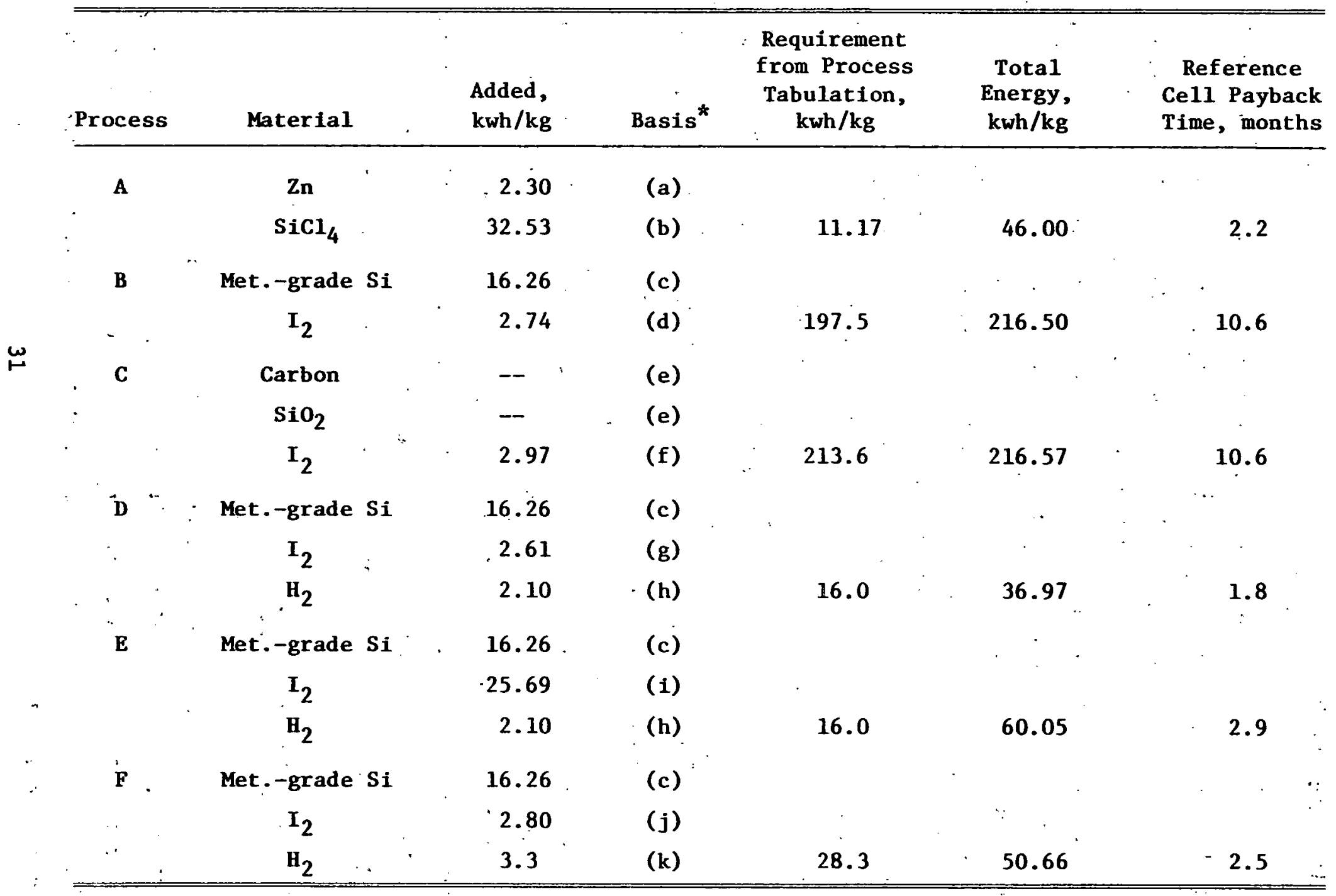

* See next page for footnotes. 


\section{Footnotes to Table 8}

(a) 1.02 pounds 2 inc reprocessed (exclusive of in-plant recycle) per $\mathrm{kg}$ silicon at $2.25 \mathrm{kwh} /$ pound (19).

(b) 13.34 pounds $\mathrm{SICl}_{4} / \mathrm{kg}$ s1licon, at energy requirement of contained chlorine $[1.65 \mathrm{kwh} /$ pound $(20)], \times 1.77$ for other requirements, total $=2.44 \mathrm{kwh} /$ pound $\mathrm{SiCl}_{4}$.

(c) $1.17 \mathrm{~kg} / \mathrm{kg}$ silicon at $11: 39 \mathrm{kwh} / \mathrm{kg}^{(21)}$ :

(d) 4.73 pounds $I_{2}$ reprocessed (esclusive of in-plant recycle) per $\mathrm{kg}$ silicon at energy cost for chlorine used in wet chlorination at 80 percent util1zation efficlency; $0.58 \mathrm{kwh} /$ pound $I_{2}$.

(e) No data readily availabile; minor energy cost not included:

(f) $5: 12$ pounds $I_{2}$ reprocessed per $\mathrm{kg}$ silicon; see (d).

(g) 4.50 pounds $I_{2}$ reprocessed per $\mathrm{kg}$ silicon; see (d).

(h) 0.07 pound $\mathrm{H}_{2}$ consumed per $\mathrm{kg}$ silicon; at $30 \mathrm{kwh} /$ pound $\mathrm{H}_{2}$ calculated on basis of cell potential of $2 \mathrm{v}(22)$ and assumed 80 percent current efficiency.

(i) 44.3 pounds $I_{2}$ reprocessed per $\mathrm{kg}$ silicon; see (d).

(j) 4.83 pounds $I_{2}$ reprocessed per $\mathrm{kg}$ silicon; see (d).

(k) 0.11 pound $\mathrm{H}_{2}$ used per $\mathrm{kg}$ silicon; see (h)..

(1) External zinc recovery of $0.46 \mathrm{~kg} \mathrm{zinc/kg} \mathrm{silicon} \mathrm{assumed} \mathrm{to} \mathrm{be} 40$ percent efficient as in-plant recycle. 
TABLE 9. DATA ON THE PREPARATION OF SILICON BY THE

FLUIDIZED-BED HYDROGEN REDUCTION OF $\mathrm{S}_{1} \mathrm{I}_{4}$

\begin{tabular}{lc}
\hline Reactor diameter & $50 \mathrm{~mm}$ \\
Bed & $328 \mathrm{~g}$ of 425 to $590 \mu \mathrm{m}$ \\
Bed temperature & $1050 \mathrm{C}$ \\
Preheater temperature & $400 \mathrm{C}$ \\
$\mathrm{S}_{4}$ vaporizer temperature & 172 to $187 \mathrm{C}$ \\
$\mathrm{H}_{2} / \mathrm{SiI}_{4}$ mole ratio & 32 \\
Run time & 40 minutes \\
Silicon deposited & $12 \mathrm{~g}$ \\
$\begin{array}{l}\text { Overall efficiency } \\
\text { Efficiency from thermo-(3) } \\
\text { dynamic calculations }\end{array}$ & 66 percent \\
\hline \hline
\end{tabular}

These results confirmed those obtained earlier at $\mathrm{BCL}(14)$ in an open-tube reactor where the experimentally determined $\mathrm{SiI}_{4}$ reduction efficiency was consistently above that predicted thermodynamically on the basis of Reference (3). Adjustments of the values for the estimated thermodynamic properties of $\mathrm{SiI}_{2}(\mathrm{~g}), \mathrm{SiH}_{2} \mathrm{I}_{2}(\mathrm{~g})$, and $\mathrm{SiHI}_{3}(\mathrm{~g})$ may accommodate the discrepancy. However, no effort was made to accomplish this other than: to determine that the difference could not be accounted for by any reasonable adjustments of the $\mathrm{SiI}_{2}(\mathrm{~g})$ estimates alone.

Experimental Iodination of $\mathrm{SiO}_{2}+\mathrm{C}$ Mixtures

One of the potential economies in the iodide process was to form the $\mathrm{SiI}_{4}$ feed material by iodination of $\mathrm{SiO}_{2}-$ plus-carbon mixtures (Process $\mathrm{C}$ ) rather than metallurgical-grade silicon. It was thus necessary to know something of the efficiency of that reaction. Accordingly, mixtures of 
lodine vapor, of from 16 to 65 percent in an argon gas carrier, were passed through a $25-\mathrm{cm}$ packed bed of ground and pressed $\mathrm{SiO}_{2}$-plus-carbon pellets. contalning stolchiometric quantities, of carbon, and 50 and 100 percent excesses of carbon, at $1523 \mathrm{C}$. Efficiencies of conversion of lodine to $\mathrm{SiI}_{4}$ of from 16 to 32 percent were observed to correlate poorly with conditions. A detalled theimodynamic analysis in the Second Quarterly Report (1) revealed that because of the competing reactions

$$
\mathrm{SiO}_{2}+2 \mathrm{C}+2 \mathrm{I}_{2}=2 \mathrm{CO}+\mathrm{SiI}_{4}
$$

and

$$
\mathrm{S}_{2}+3 \mathrm{C}=2 \mathrm{CO}+\mathrm{SiC}
$$

and the vartation of equilibrium composition with the solid phases present (see Flgure 8), it would not be possible to calculate the expected conversion. The question as to whether the addition of hydrogen would ald the conversion was answered in the negative as can be seed from the figure.

A nominal conversion efflciency of 20 percent was adopted in calculating the costs of Process $C$. 


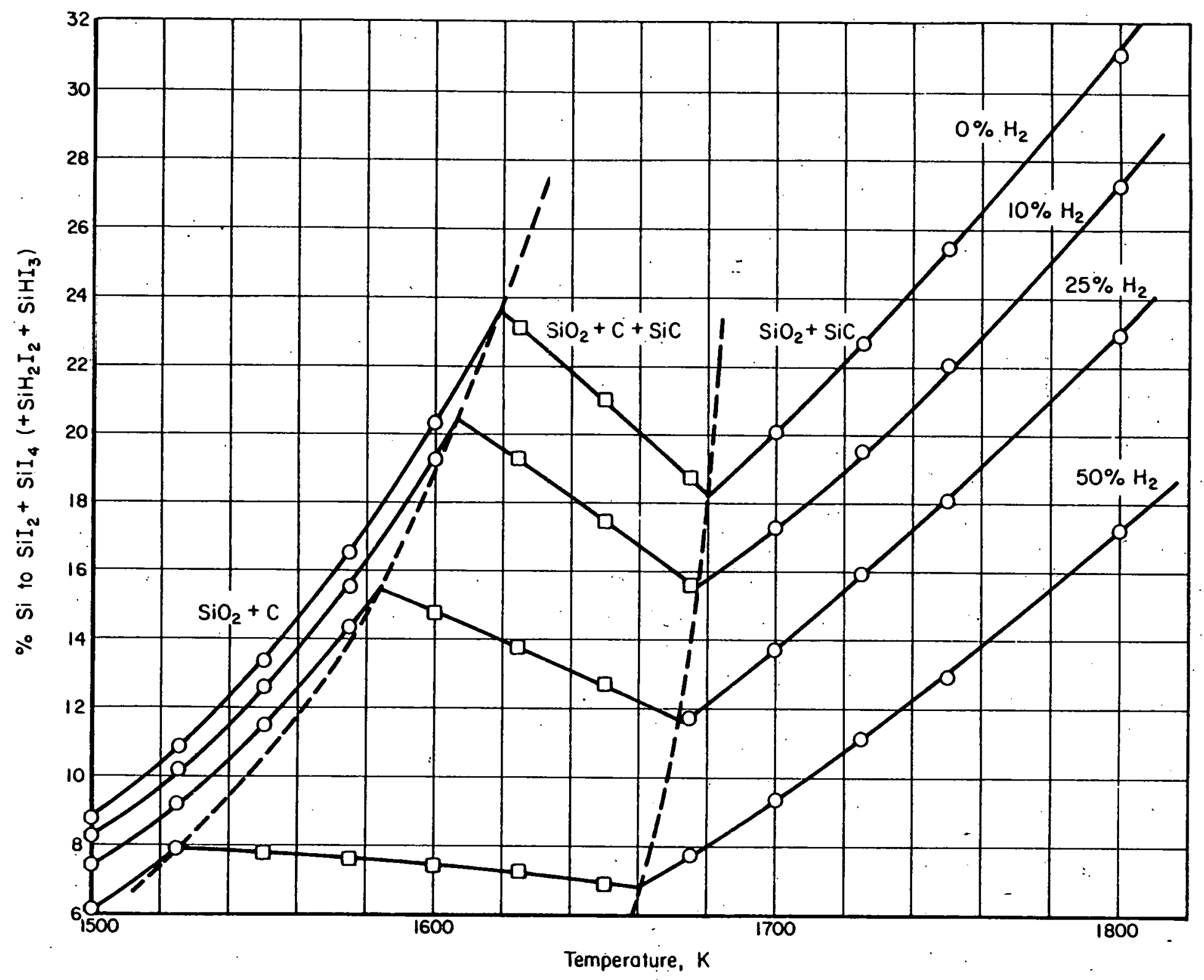

FIGURE 8. IODINATION OF SILICON OXIDE-CARBON MIXTURES

(Equilibrium conversion as functions of temperature and percent $\mathrm{H}_{2}$ added to $\mathrm{I}_{2}(\mathrm{~g})$, showing region of stability of solid phases starting with stoichiometric $\mathrm{C} / \mathrm{SiO}_{2}$ ratio $=2 / 1$ ) 
C. ZINC REDUCTION PROCESS DEVELOPMENT

In the early days of the semiconductor silicon industry, DuPont produced silicon by the batchwise zinc reduction of $\mathrm{SiCl}_{4}$ having the characteristics given in Table 10.

TABLE 10. SPECIFICATIONS FOR DUPONT SILICON ${ }^{(23)}$

\begin{tabular}{lcccc}
\hline & Grade I & Grade II & Grade III & $\begin{array}{c}\text { Solar } \\
\text { Cell } \\
\text { Grade }\end{array}$ \\
\hline $\begin{array}{l}\text { Boron Content (ppb)* } \\
\text { Minfmum Res1stivity } \\
\text { for Top 60 Percent } \\
\text { of Crystal (ohm cm) }\end{array}$ & 1 & 1 to 3 & 6 to 11 & \\
"P" Type & 100 & 50 & 25 & 0.5 \\
"N" Type & 25 & 15 & 5 & 0 \\
\hline
\end{tabular}

* Calculated from reslstivity of float-zoned bar cut from Czochralsk1 crystal.

This materlal was of varlable quality, and although contacts with DuPont have not resulted in more definitive information on minority carrier I1fetime, etc., it is understood that solar cells with efficlencies of 10 to 12 percent were made.

The standard DuPont product was a mass of dendrites, difficult to handle in further processing. Recognizing the limltations of the process, DuPont brlefly experimented with the fluldized-bed approach. In the example given in their patent (24), essentially stolchlometric quantites of $z$ inc and $\mathrm{SICl}_{4}$, vapors were passed through a $\sim 10-\mathrm{cm}$-deep bed of $250-$ to $590-\mu \mathrm{m}$ silicon particles at $900 \mathrm{C}$. About 21 percent of the silicon fed as $\mathrm{SiCl}_{4}$ 
was deposited on the particles with an equal amount of silicon fines being collected with the reaction product.

With improvements in fluidized-bed technology since that time, it was believed possible to improve the yield of silicon on the seed particles and to take advantage of the potential for continuous operation provided by the fluldized bed, which should lead to increased uniformity of product.

The discussions imediately following include the theoretical and experfmental work that has gone into assessing the technical feasibility of the process.

\section{Thermodynamic Analysis}

Fortunately, the reaction temperature level of interest is high enough that reaction kinetics does not appear to be controling, and the silicon yield is practically thermodynamically and supply limited.

The thermodynamic data given in Table 11 were used to calculate the equilibrium conversion efficlencies for the reaction

$$
2 \mathrm{Zn}(g)+\mathrm{SICl}_{4}(g)=\mathrm{S} 1(\mathrm{~s})+2 \mathrm{ZnCl}_{2}(\mathrm{~g}, l)
$$

under several condtitions. It was determined that $\mathrm{ZnCl}(g)$ and $\mathrm{Zn}_{2} \mathrm{Cl}_{4}(\mathrm{~g})$ were insignificant species, although $\mathrm{SICl}_{2}(\mathrm{~g})$ was included in the analysis. Where the effect of using hydrogen as a diluent was explored, the specles $\mathrm{H}_{2}(g)$,' $\mathrm{S}_{1 H} \mathrm{Cl}_{2}(\mathrm{~g}), \mathrm{S}_{1} \mathrm{HCl}_{3}(\mathrm{~g})$, and $\mathrm{HCl}(\mathrm{g})$ were added.

Based on the results of the thermodynamic calculations, Figure 9 shows the decrease in efflclency with increasing temperature to be expected from the exothermic nature of the reduction reaction. The decreased efficlency effected by dilution with inert gas for this reaction which has a net decrease in molar volume is also reflected.

The effect of hydrogen dilution is also shown in Figure 9 . Although a "reducing agent", hydrogen is less effective than zinc, and the net effect is an actual reduction of conversion efficiency due to the formation of the chlorosilanes $\mathrm{SIHCl}_{3}$ and $\mathrm{SiH}_{2} \mathrm{Cl}_{2}$ at lower temperatures.

A clear limitation on the operating range is indicated by the appearance, at the inflection, of $\mathrm{ZnCl}_{2}(l)$ as a condensed phase below $727 \mathrm{C}$. Operating in this range for higher efficiency (assuming that kinetic limitations would not set $1 \mathrm{n}$ ) is attractive but impractical, as the accumulation of liquid $\mathrm{ZnCl}_{2}$ in the bed would result in agglomeration of the bed particles. 


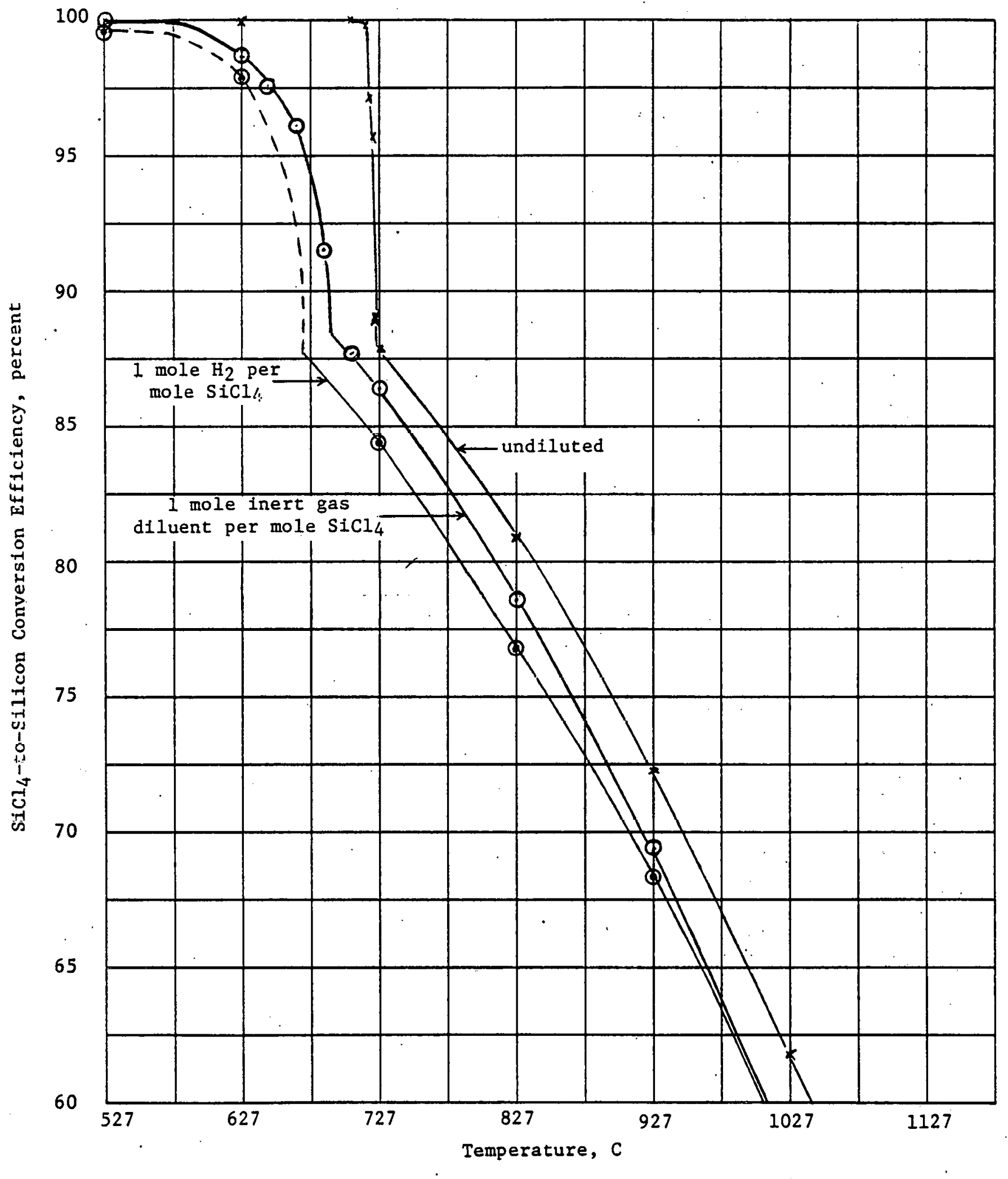

FIGURE 9. CONVERSION EFFICIENCY, $2 \mathrm{Zn}+\mathrm{SiCl}_{4}=2 \mathrm{ZnCl}_{2}+\mathrm{S} 1,1$ atm 
TABLE 11. THERMODYNAMIC PROPERTIES OF $\mathrm{ZnCl}_{2}$

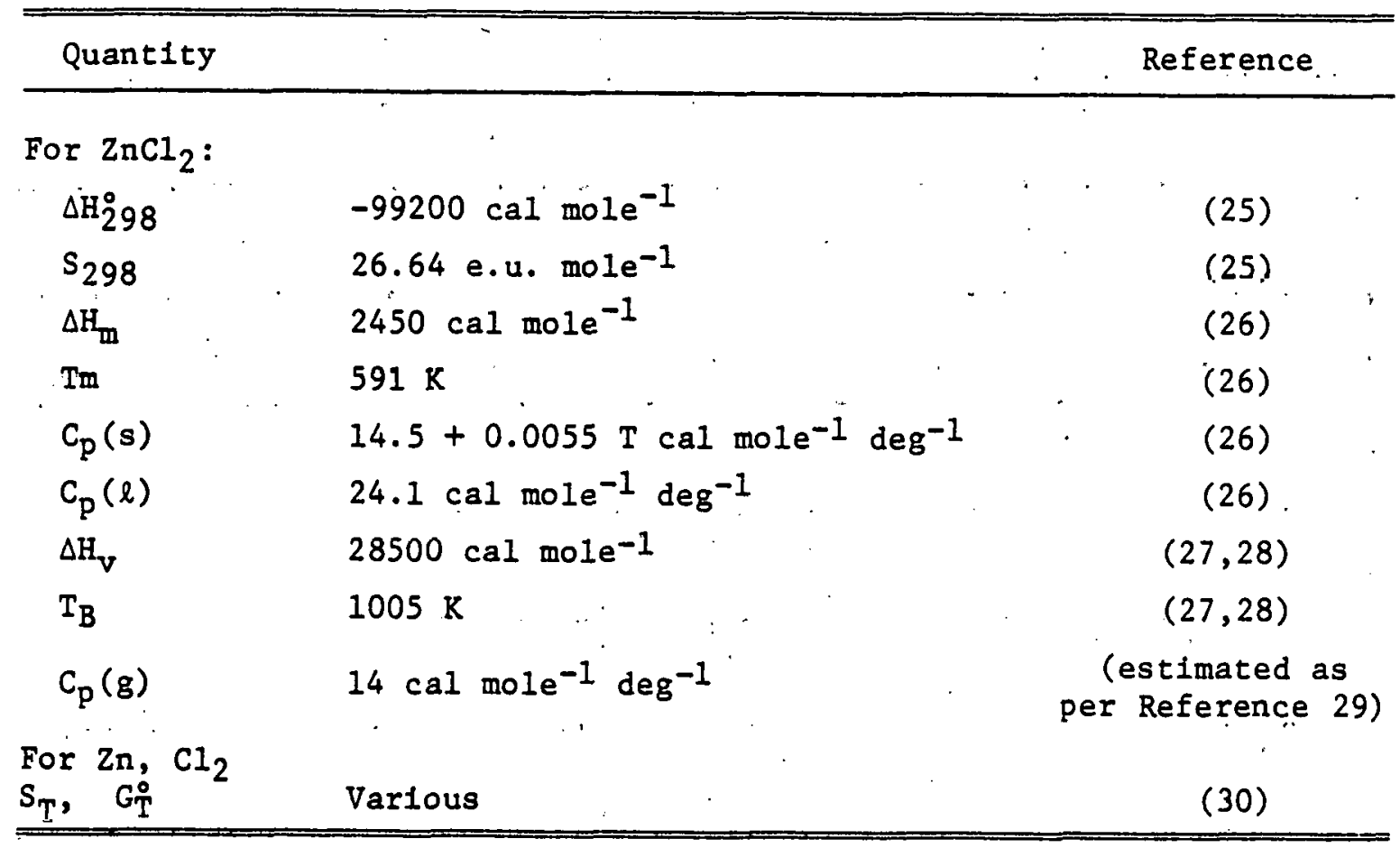

Another and potentially more serious Iimltation exists at the entrance end of the reactor, that 1s, the dew point of the unreacted 2 inc, $908 \mathrm{C}$ for 1 atm and correspondingly hlgher for higher pressures. Not only would the condensation of liquid zinc in the bed lead to 1 ts agglomeration and loss of fluldization, but it has been shown that very fine silicon whiskers nucleate on the Ilquid $z$ inc surface and are entrained in the . fluldizing gas and lost to the seed particles, or if generated in sufficlent quantity,. can form atporous mass in the reactor outlet and obstruct the Elow.

W1th the above 11mitations in mind, it was declded to adopt $1200 \mathrm{~K}$ (927 C) as the nominal operating temperature, where the equilibrium efficlency is 72 percent for the undliuted gas.

Later in the work the concept of a graded bed temperature was adopted, whereby the upper part of the bed, in which the dew point of the 
partially reacted zinc was lower, could be cooled somewhat to gain efficiency. This option obviously becomes more feasible with increasing bed-height-todiameter ratio.

Figure 10 shows the relatively small effect of dilution on conversion efficiency and Figure 11 shows the effect of stoichiometry of the . feed gas on the efficiency of conversion of zinc to $\mathrm{ZnCl}_{2}$ and $\mathrm{SiCl}_{4}$ to silicon. The expected increased efficiency of conversion of one reactant in an excess of the other is evident. That the zinc and $\mathrm{SiCl}_{4}$ conversion efficiencles are not equal at $2 / 1$ stoichiometry lies in the fact that whereas the $z$ inc is constrained to form $\mathrm{ZnCl}_{2}, \mathrm{SiCl}_{4}$ can form $\mathrm{Si}(\mathrm{s})$ or $\mathrm{SiCl}_{2}(\mathrm{~g})$, the fracrion of the latter increasing with temperature (e.g., 1 percent of the $S i C l_{x}$ at $827 \mathrm{C}$ and 4 percent of the $\bar{S} i C l_{x}$ at $y \dot{2} 7 \mathrm{C}$ ).

\section{Effect of Stoichiometry} on Product Cost

Because of the difference, in principle, of the cost of recycling unreacted zinc and unreacted $\mathrm{SiCl}_{4}$, it became of interest to analyze the cost of off-stoichiometry operation, which should show a minimum on one side or the other. Detalls of the approach are given in the Third Quarterly Progress Report(1). However, it involves basically adfusting the sizes of all of the process units affected by a change in stoichiometry and adding or subtracting a proportlonace amount to tlie cost of the product, using the values for $2 / 1$ stoichiometry as reference. The reactant conversion efficlencies used in the calculations for $2 \mathrm{n} / \mathrm{SiCl}_{4}$ mole ratios of from 0.8 to 5 were those predicted thermodynamically.

Table 12 gives the results for the capital-, energy-, and materials-: related costs. The labor-related costs were assumed not to change significantly. Two conclusions can be drawn from the data of Table 12.

(1) No marked economic advantage exists in operating at a $\mathrm{Zn} / \mathrm{SiCl}_{4}$ ratio of other than $2 / 1$; the savings gained by increased efficlency in utilization of one reactant 


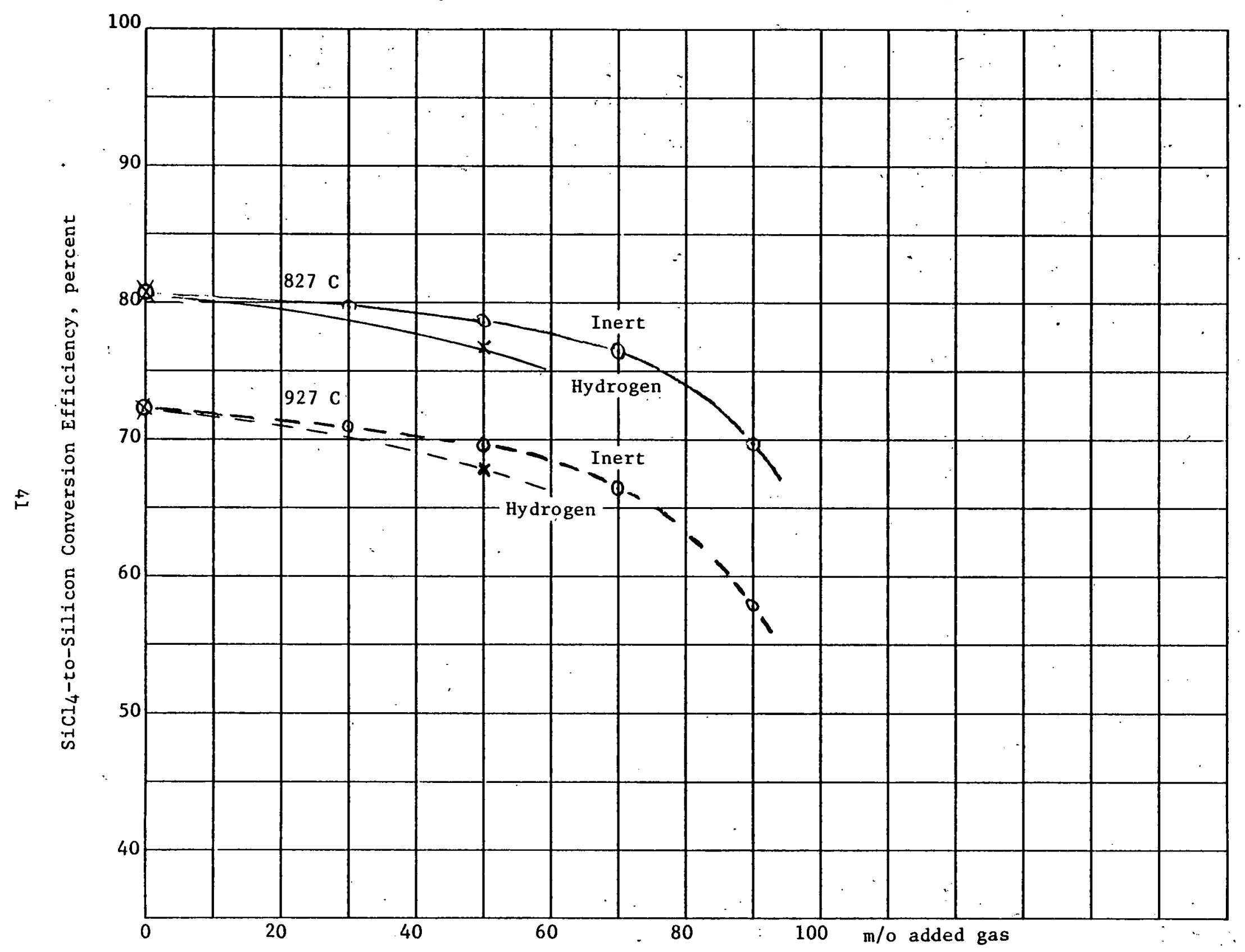

FIGURE 10. EFFICIENCY VERSUS DILUTION OF $\mathrm{SiCl}_{4}$ WITH INERT GAS (o) AND HYDROGEN ( $x$ ), 1 atm 


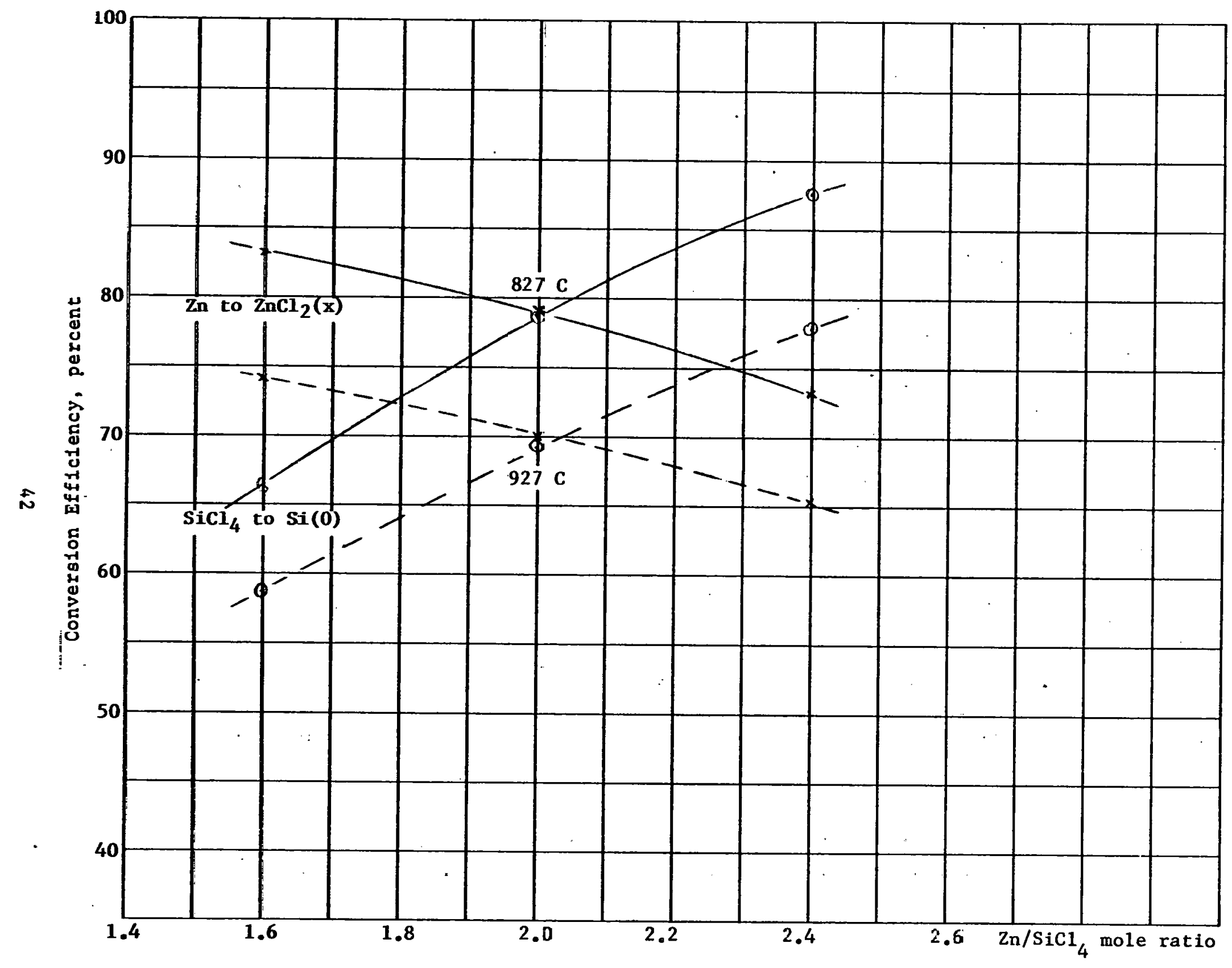

FIGURE 11. EFFICIENCY VERSUS STOICHIOMETRY IN Zn REDUCTIDN OF $\mathrm{SiCl}_{4}$ (DILUTED 1/1 WITH INERT GAS 
TABLE 12. ADDED COST (DOLLARS PER $\mathrm{kg}$ SILICON) OF OFF-STOICHIOMETRY OPERATION FOR FLUIDIZED-BED ZINC REDUCTION OF SILICON TETRACHLORIDE AT $1200 \mathrm{~K}, 1 \mathrm{~atm}$

\begin{tabular}{|c|c|c|c|c|c|c|c|c|}
\hline $\begin{array}{l}\text { Mole Ratio } \\
\mathrm{Zn} / \mathrm{SiCl}_{4}\end{array}$ & $\begin{array}{c}\text { Zinc } \\
\text { Equipment }\end{array}$ & $\begin{array}{c}\mathrm{SiCl}_{4} \\
\text { Equipment }\end{array}$ & $\begin{array}{c}\text { Fluidized } \\
\text { Bed }\end{array}$ & $\begin{array}{c}\text { Zinc } \\
\text { Materials }\end{array}$ & $\begin{array}{l}\text { Zinc } \\
\text { Energy }\end{array}$ & $\begin{array}{c}\mathrm{SiCl}_{4} \\
\text { Materials }\end{array}$ & $\begin{array}{l}\mathrm{SiCl}_{4} \\
\text { Energy }\end{array}$ & Total \\
\hline $\begin{array}{l}0.80 \\
1.00 \\
1.20 \\
1.40\end{array}$ & $\begin{array}{l}-0.035 \\
-0.031 \\
-0.027 \\
-0.021\end{array}$ & $\begin{array}{l}0.171 \\
0.117 \\
0.080 \\
0.051\end{array}$ & $\begin{array}{l}0.051 \\
0.031 \\
0.018 \\
0.009\end{array}$ & $\begin{array}{l}-0.049 \\
-0.044 \\
-0.038 \\
-0.030\end{array}$ & $\begin{array}{l}-0.012 \\
-0.011 \\
-0.010 \\
-0.007\end{array}$ & $\begin{array}{l}0.283 \\
0.171 \\
0.112 \\
0.070\end{array}$ & $\begin{array}{l}0.074 \\
0.048 \\
0.031 \\
0.020\end{array}$ & $\begin{array}{l}0.483 \\
0.281 \\
0.166 \\
0.092\end{array}$ \\
\hline $\begin{array}{l}1.60 \\
1.80 \\
2.00 \\
2.22\end{array}$ & $\begin{array}{r}-0.015 \\
-0.008 \\
0.000 \\
0.009\end{array}$ & $\begin{array}{r}0.028 \\
0.014 \\
0.000 \\
-0.011\end{array}$ & $\begin{array}{l}0.004 \\
0.001 \\
0.000 \\
0.001\end{array}$ & $\begin{array}{r}-0.022 \\
-0.010 \\
0.000 \\
0.016\end{array}$ & $\begin{array}{r}-0.006 \\
-0.003 \\
0.000 \\
0.004\end{array}$ & $\begin{array}{r}0.039 \\
0.018 \\
0.000 \\
-0.014\end{array}$ & $\begin{array}{r}0.011 \\
0.005 \\
0.000 \\
-0.004\end{array}$ & $\begin{array}{l}0.039 \\
0.017 \\
0.000 \\
0.001\end{array}$ \\
\hline $\begin{array}{l}2.50 \\
2.86 \\
3.33 \\
4.00\end{array}$ & $\begin{array}{l}0.028 \\
0.051 \\
0.088 \\
0.139\end{array}$ & $\begin{array}{l}-0.022 \\
-0.030 \\
-0.036 \\
-0.042\end{array}$ & $\begin{array}{l}0.004 \\
0.012 \\
0.025 \\
0.046\end{array}$ & $\begin{array}{l}0.040 \\
0.076 \\
0.132 \\
0.216\end{array}$ & $\begin{array}{l}0.010 \\
0.019 \\
0.033 \\
0.055 .\end{array}$ & $\begin{array}{l}-0.027 \\
-0.036 \\
-0.044 \\
-0.051\end{array}$ & $\begin{array}{l}-0.008 \\
-0.010 \\
-0.012 \\
-0.014\end{array}$ & $\begin{array}{l}0.025 \\
0.082 \\
0.186 \\
0.349\end{array}$ \\
\hline 5.00 & 0.213 & -0.045 & 0.080 & 0.352 & 0.089 & -0.054 & -0.015 & 0.620 \\
\hline
\end{tabular}


are roughly balanced by the cost of decreased

efficlency in utilization of the other.

(2) The added cost of operating with as much as

43 percent excess of either reactant

$\left(2 \mathrm{n} / \mathrm{SiCl}_{4}\right.$ ratios between 1.4 and 2.86$)$ is

less than $\$ 0.10 / \mathrm{kg}$ silicon.

Actually, when the data of the last column of Table 12 are plotted as a function of $\mathrm{Zn} / \mathrm{SICl}_{4}$ rat1o, a minimum is observed at $\mathrm{Zn} / \mathrm{SICl}_{4}, \mathrm{2} .1$; however, the corresponding cost saving of $\sim \$ 0.002 / \mathrm{kg}$ silicon is insignificant.

Although the prospect of appreclable cost savings lin offstolchlometry operation does not exist, the second of the above conclusions Is significant in two respects.

(1) Strlct control of stoichiometry is not mandatory from an economic standpoint.

(2) If any advantages in kinetics or in, the form or purity of the product were to accrue from operation at $\mathrm{Zn} / \mathrm{SICl}_{4}$ ratios $\$ 2 / 1$, 1t $1 \mathrm{~s}$ posstble that they might be obtained at relatively low cost, depending upon the degree of departure from stolchlometry required.

\section{Experimental Fluldized-Bed}

ZInc Reduction of $\mathrm{SICl}_{4}$

Durlng the course of this program, nearly 100 experimental runs were made in which silicon tetrachloride was reduced with $z$ inc in small fluldized-bed reactors of varlous deslgns and under varlous conditions. Runs to prepare materlal for product qual1ty evaluation were made under a nominal set of conditions that ylelded no concluslons other than confirmation of prevlous results.

In all cases, fused quartz was the material of construction. The reactor dlameter, $\sim 50 \mathrm{~mm}$, was chosen as a compromise between the destre to limit the consumption of feed materials and the size of assoclated feeding 
equipment and facilitation of the fabrication, in fused quartz, of the bed support designs that would provide for the various options of reactant introduction and bed dynamics'desired.

The run time in the inftial equipment was limited by the capacity of the zinc feed and zinc chlorlde condensation systems. A "miniplant" constructed later provided for increased capacity as well as for transfer of the condensed zinc chloride to an experimental electrolytic cell.

Rather than to summarize all of the data, this section of the report is organlzed with reference to varlous subjects of Interest and the related conclusions drawn. In each case, reference to the Quarterly Report is glven in which more detalls can be found.

\section{Sol1d Versus Gaseous Z1nc Feed}

Because of the difficulty of bolling zinc and feeding it at a controlled rate to a flutitien bed, the possibility of metering solid zinc granules to the fluldized bed from above was explored. Favorable results with feeding solfd volatile reactants directly to fluldized beds had been experfenced at BCL in the coating of nuclear fuel particles; vaporization occurs within the fluldized bed and the CVD reaction ensues. Accordingly, a reactor of the design shown in Flgure $12 \mathrm{a}$ was used to test the concept, with results given in the First Quarterly Report(1). The solld zinc granules used were of $550-\mu \mathrm{m}$ dlameter. From $\sim 120$ to $2237 \mathrm{~g}$ of $210 \times 297-\mu \mathrm{m}$ s1l1con seed particles were used as the fluldized bed. Despite varlations of the temperature between $750 \mathrm{C}$ and $1000 \mathrm{C}$ and the $\mathrm{zn} / \mathrm{SICl}_{4}$ rat10 from 0.6 to 4 (stolchiometry $=2$ ), no silicon was deposited on the seed particles. Rather, a mass of silicon needles, from 100 to $1000 \mu$ m long and 0.2 to $0.4 \mu \mathrm{m}$ across, was formed downstream of the bed; the higher the bed temperature, the farther downstream, suggesting that the needle formation resulted from heterogeneous reaction on condensed $z$ inc droplets. While it is true that some needles may have formed on the zinc particles introduced into the bed, those needles were probably elutrlated and carrled downstream. 


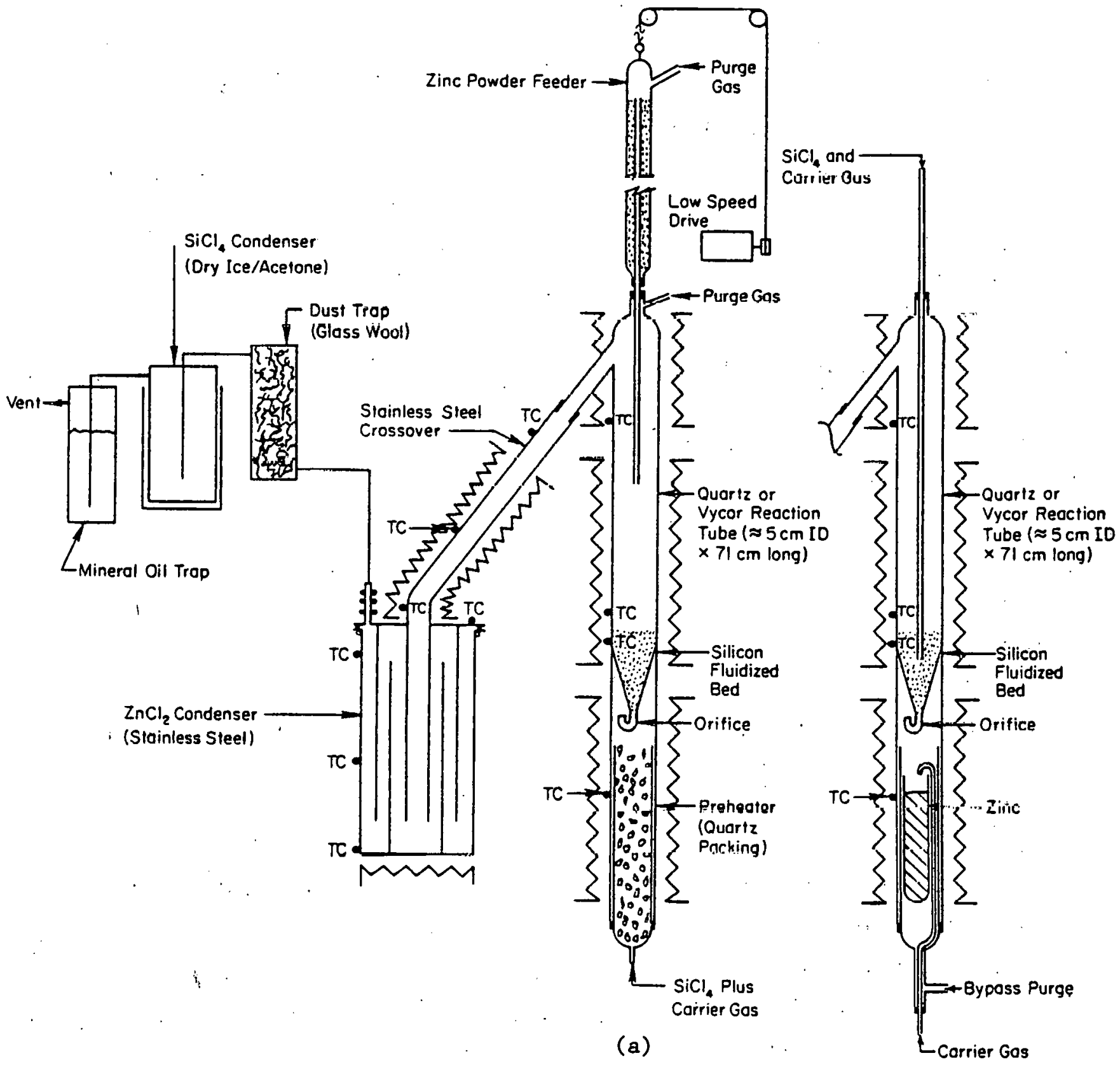

(b)

FIGURE 12. SCHEMATIC DIAGRAM OF UNIT FOR THE PREPARATION OF SILICON BY THE ZINC REDUCTION OF S1C1 4

(a) SOLID ZINC FEED

(b) VAPOR ZINC FEED 
By contrast, when $z$ Inc was fed as the vapor at temperatures of from 900 to $1027 \mathrm{C}$ in the apparatus of Figure $12 \mathrm{~b}$, and $\mathrm{zn} / \mathrm{SICl}_{4}$ ratios from 0.55 to 1.8 in $\sim 70 \mathrm{~m} / 0$ diluent gas, over 96 percent of the silicon produced was collected as dense materlal on the seed particles. $\mathrm{SiCl}_{4}$ conversion efficiencles in the range of 12 to 40 percent were obtalned, corresponding to from 60 to 100 percent of those expected thermodynamically under any given condition. The predicted ineffectiveness of hydrogen as an added reductant was confirmed.

Accordingly, the concept of using a solid zinc feed was abandoned In favor of the vapor feed technique.

Use of D1luent or Carrier Gas

Although in many CVD reactions an inert carrier gas is used for convenfence in transporting materlals, it is recognized that to obtain the highest possible production rate from a fluldized-bed reactor where the throughput is 1imited by potential elueriation of the bed particles, the reactants should be und1luted. However, In the present case, with most of the reaction products constituted of condensible materials, a diluent gas (argon or hydrogen) was used inftially to avold potential problems with decreased pressure due to condensation of reaction products. Hence, early deposition rates were from 10 to 40 grams of silicon per hour in a 5-cmdlameter fluldized bed. In later work such as that described in the Fifth/ SIxth and Seventh Quarterly Progress Reports(1); In which the diluent was decreased to a few percent* (typlcally 3 to 4 percent), much higher rates (above $300 \mathrm{~g} /$ hour) were obtalnable than would have been the case with normal concentrations of dlluent or carrier gas.

Not only does the increased production rate per unit cross section of the fluldized bed demand the minimization of dlluent content, but the cost of the letter, if discarded, or of 1 to recycle 1 reclatmed, is an Important factor in demanding minimum use.

* Some noncondensible gas is necessary to allow the system to "breathe". 


\section{Fluidized-Bed Dynamics}

In any chemical vapor deposition reaction leading to the growth of particles in a fluidized bed, it is essential that the particles be kept in. motion relative to each other, otherwise the points of contact can be bridged by deposited material, leading to agglomeration. Further, a layer of stagnant particles exposed to the reactant gases will become coated with reaction product. To avoid stagnation, the bed action must be vigorous, However, it is also desirable to expose all particles to the same reaction conditions on the average and to limit access of the reactant gas to the wall of the fluidized bed. The latter objectives may be met by using the proper combination of particle size, gas flow, and design of the reactant inlet system and associated bed support plate. A net flow of particles up the center area and downward along the reactor wall is desirable, similar to the particle motion in a spouted bed but without the continuous dilute phase along the axis of the inlet and general absence of gas bubbles that characterize the latter. The presence of a relatively dense descending layer of particles along the walls is desirable to minimize contact of the reactants with the wall and thus prevent, or at least minimize, "wall depnsitinn", Such particlo movoment requires that the reactant inlet(s) be located away from the wall of the reactor, and that the wall in the vicinity of the distributor plate be sloped inward toward the reactant inlet (s).

Frequently a cone-bottom reactor is used, which is convenient for deposition from one reactant or for a reaction where a second reactant can be introduced through a dip tube (Figure $12 \mathrm{~b}$ ). In a lárger reactor, it is preferable to bring both reactants in from the bottom; however, it was found early in the present work that providing adjacent inlets for the zinc and $\mathrm{SiCl}_{4}$ vapors at the apex of a cone-bottom reactor, such as shown in Figure 13, Design $B$, was not satisfactory because of silicon deposition in the cone area. A more satisfactory design was that shown in Figure 13, Design A, with a hemispherical bottom and multiple inlets; however, with the zinc vapor fed through the outside inlets and $\mathrm{SiCl}_{4}$ through the center, deposition of silicon on the reactor wall was still a problem, and unless conditions 


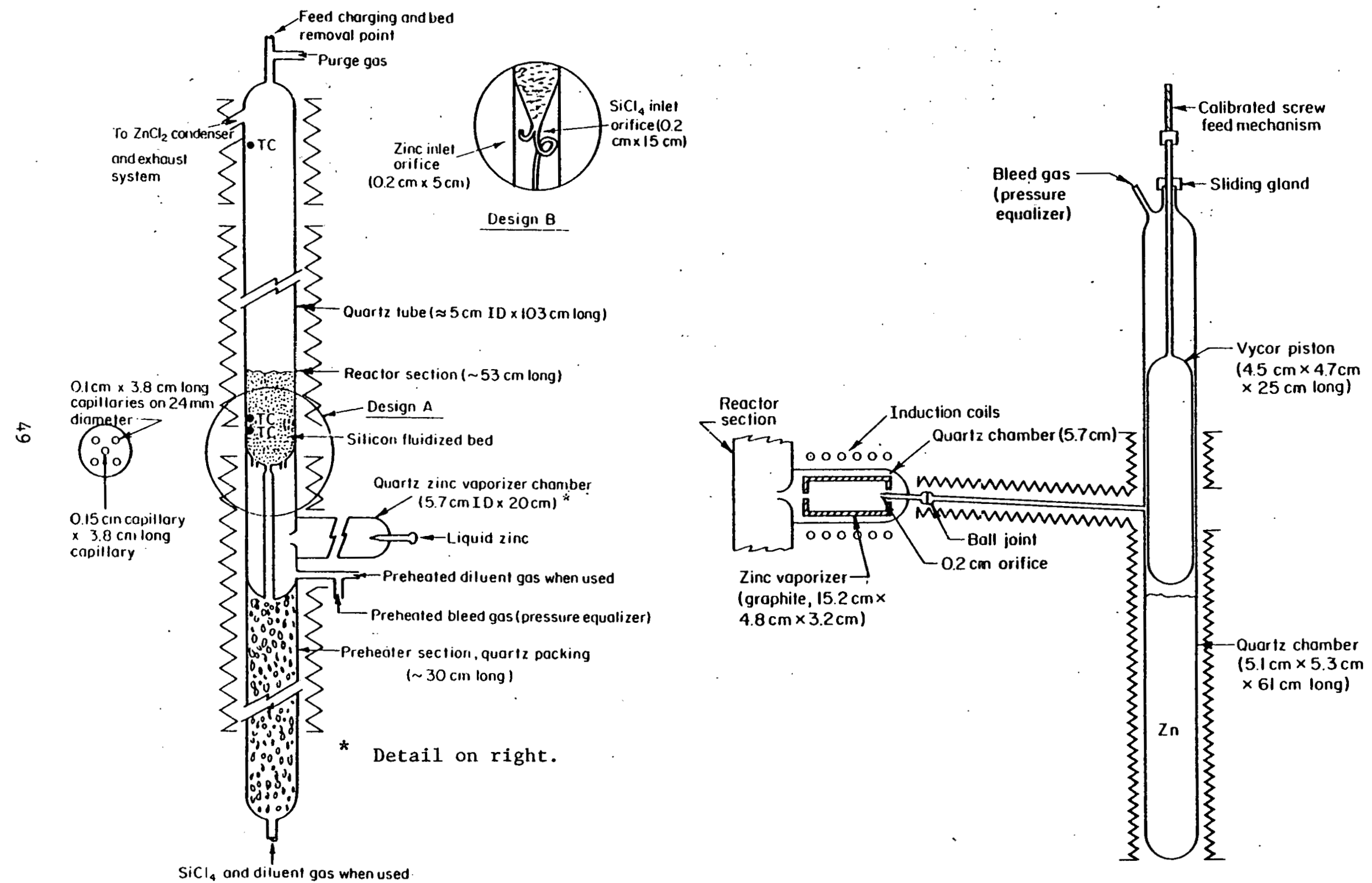

FIGURE 13. SCHEMATIC DIAGRAM OF FLUIDIZED-BED REACTOR FOR THE PREPARATION OF SILICON BY THE ZINC (VAPOR FEED) REDUCTION OF $\mathrm{SiCl}_{4}$

(The zinc feed system is shown on the right) 
were "right" (a combination of parameters not well defined), tubes of agglomerated particles coated with silicon were observed to grow upward through the bed as extensions of one or more of. the zinc vapor inlets. The most sat1sfactory design, and that finally adopted [F1fth/S1xth Quarterly Report(1)], was to bring the zinc in from the center Inlet and the $\mathrm{SiCl}_{4}$ from the outer inlets.

It had been consistently observed that deposition occurred preferentially in the areas of high zinc concentration. This behavior can be rationalized on the basis that for the reaction

$$
\mathrm{SiCl}_{4}(g)+2 \mathrm{Zn}(\mathrm{g})=\mathrm{S} 1(\mathrm{~s})+2 \mathrm{ZnCl}_{2}(\mathrm{~g})
$$

kinetic expressions might be expected to involve a squared term in the concentration of zinc.

With the zinc vapor introduced in the center, deposition of silicon on the wall was limited in most runs to the area above the fluidizing bed, Indicating that with deeper beds attainable in scaled-up reactors, reduction of the fraction of silicon deposited on the wall might be obtained beyond that expected merely from the decrease of the ratio of wall area per unit bed helght to cross sectional area as the bed diameter is increased.

Other important aspects of particle dynamics in fluldized-bed deposition on seed particles are (1) particle growth and (2) discharge of product. In the present case, it is intended that seed particles be prepared Initlally from semiconductor-grade silicon, and eventually from the recycled product, by crushing, screening, and leaching. (Information on this operation. 1s. given in the Product Quality Section of this report.) It is desirable that the seed content of the product be minimized for two reasons:

(1) To minimize the contribution of 1mpurities from the seed

(2) To minimize the cost of producing seed.

Although an economic optimum obviously exists, the seed content of the product chosen for process design purposes is 5 percent, corresponding to a ratio of deposited material to seed of 19 and an average increase in particle 
diameter, in a batchwise operation, by a factor of 2.7. In actual practice at a constant bed inventory and with seed particles fed semicontinuously at a prescribed fraction of the production rate, the product will show a characteristic size distribution after the system has reached a steady state(31). In theory, with the violent mixing that is characteristic of the level of fluidization required, a finite number of particles on the tail of the distribution curve could grow to very large size; however, in practice, with particle withdrawal at the bottom, appreciable segregation occurs apparently in the vicinity of the high velocity incoming gas jets where the terminal velocity of the larger particles is not reached*, but where the smaller particles are blown back into the bed mixture, with the larger ones left behind.

This behavior has been demonstrated with a mixture of sand containing glass balls of about ten times the diameter of the sand particles amounting to . less than 0.1 percent of the total bed weight. Under normal fluidization, the rate of ball discharge was about twice that of the sand discharge.

Although it is expected to be less of a problem in the larger experimental facility, condensation of zinc on the product (as semicontinuousiy withdrawn from the tube at the bottom of the bed) was observed in the "miniplant"**. In the extreme, condensation of zinc or $\mathrm{ZnCl}_{2}$ has been observed to plug the withdrawal tube. Proper operation of the product withdrawal system depends upon balancing the purge gas flow in the exit line so that pressure surges in the reactor do not drive the zinc or $\mathrm{ZnCl}_{2}$ vapor down the withdrawal tube to where the temperature of the tube and its contents is below the dew point of the vapor. This requires a balance of purge rate. It is obvious that the product should be withdrawn slowly and as nearly continuously as possible. Surges of product result in displacement of the vapor in the interstices. High rates of purge are beneficlal in limiting penetration of vapor into the

* To prevent discharge into the reactant inlet system, the velocity in the gas inlet proper must obviously exceed the terminal velocity of the largest particles.

** Approximately 5-cm-dlameter experimental unit. 
withdrawal tube as the pressure at the bottom of the bed fluctuates. However, cooling of the exit tube increases with increasing purge, driving the zone at the dew point of the vapor closer to the reactor and making it more accessible to condensation during pressure surges. Clearly, a balance must be struck.

After a number of alternatives were considered in the light of the above factors, distributor plates of various design were tested in a fullscale mock-up using sand as the particles and air as the fluidizing gas. In this work, described in the Ninth and Tenth Quarterly Reports(1), the design shown in Figure 14 gaves the most acceptable bed action as judged from visunl observation and from slow-moclon plicures, and with minor mndifications in dimensions, has been adopted for the design of the experimental facility. Figure 15 is a typical eequence of frames from the motion pictures, showing first a collapsed bed, gradually expanding bed with brealcing of the bubble through the top of the expanded bed, and finally return of the bed to the collapsed condition. At the scale shown, it is obviously not possible to discern the predominant motion of the particles downward along the walls in the bottom section of the bed that is readily observed visually.

\section{Rate and Efficiency of}

\section{Sil1con Pluluction}

As discussed ahove in part, the rate of silicon production to be expected from the zinc reduction appears to be limited by the thermodynamic equilibrium and the rate of feed of reactants to the fluidized bed. The permissible throughput is a function of the particle size and particle size distribution. The major product is a dense deposit of silicon on the seed particles; however, two co-products must be considered, (1) silicon deposited on the wall and (2) that formed as finely divided particles that escape the bed. For most economical operation, the yield of the major product must be maximized and the throughput also maximized.

With these as the major objectives, a large number of experimental runs were made in $5-\mathrm{cm}-$ diameter clear quartz reactors of various design, 


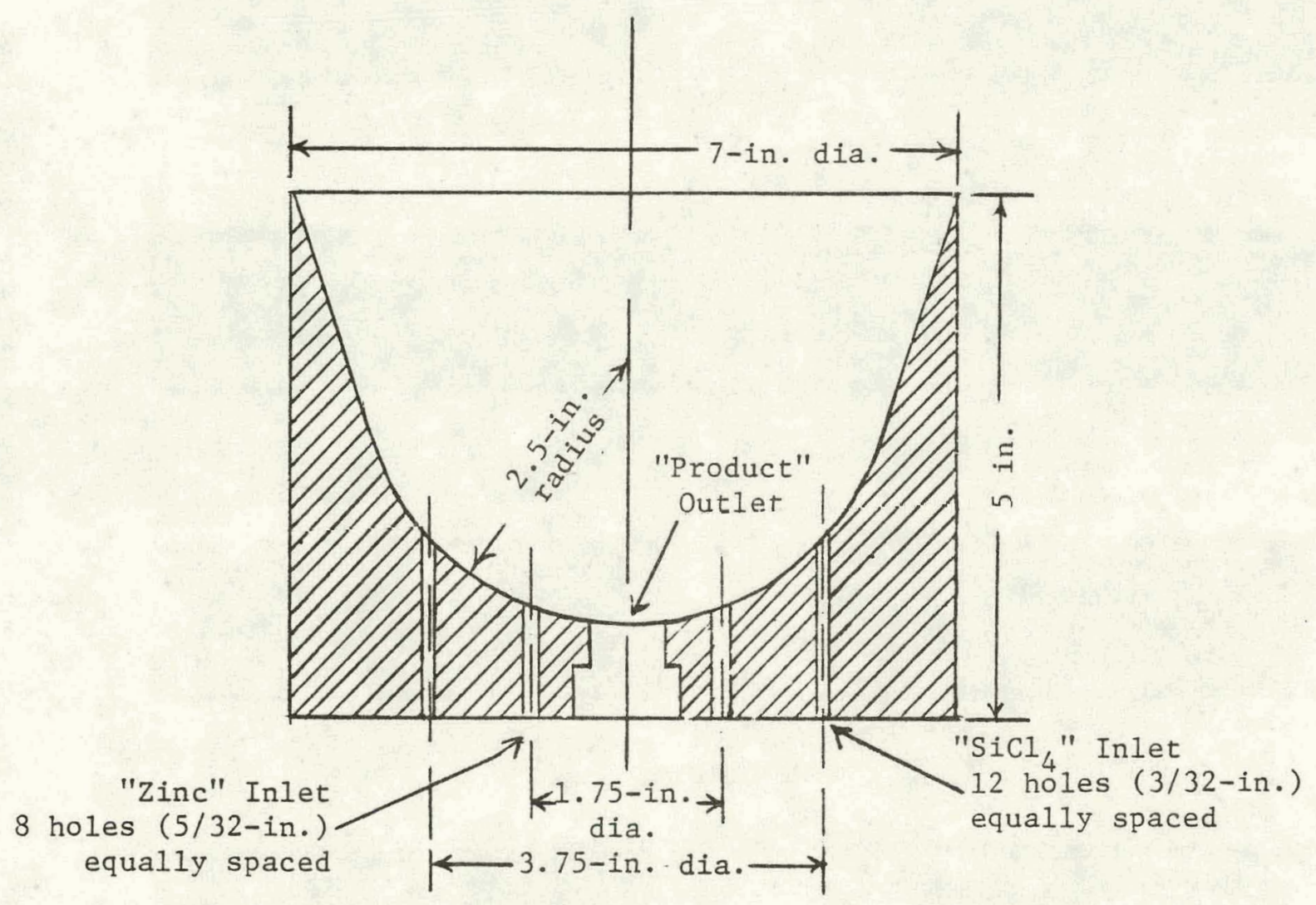

FIGURE 14. DIAGRAM OF ROUND-BOTTOM DISTRIBUTOR USED IN MODEL STUDIES 

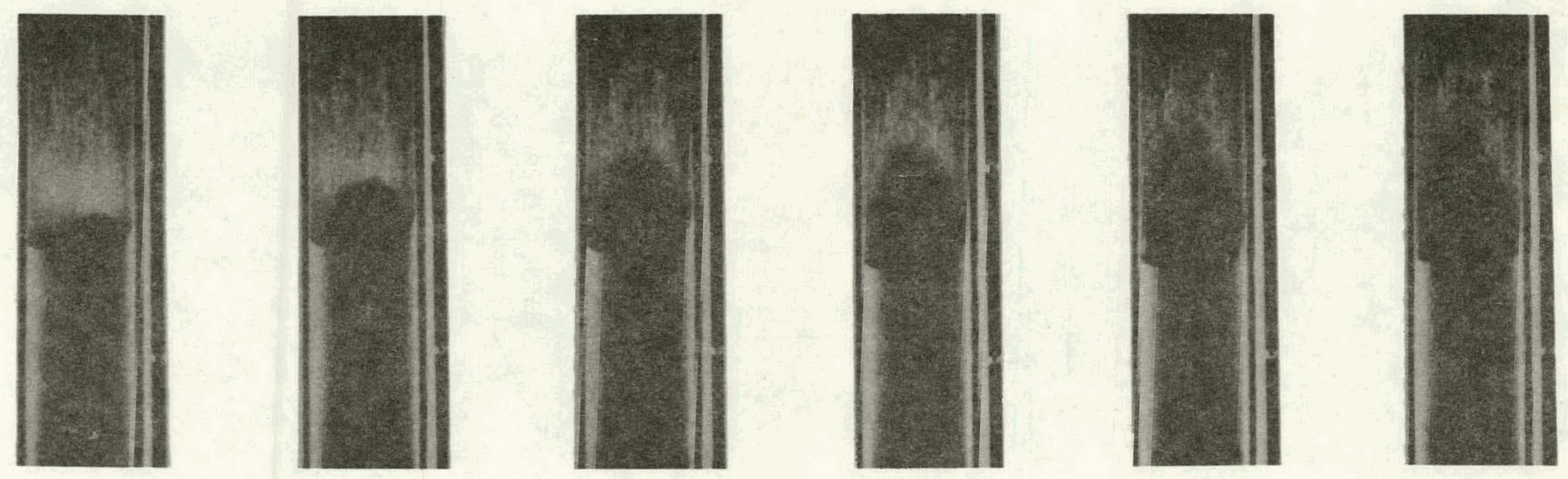

\section{UT}
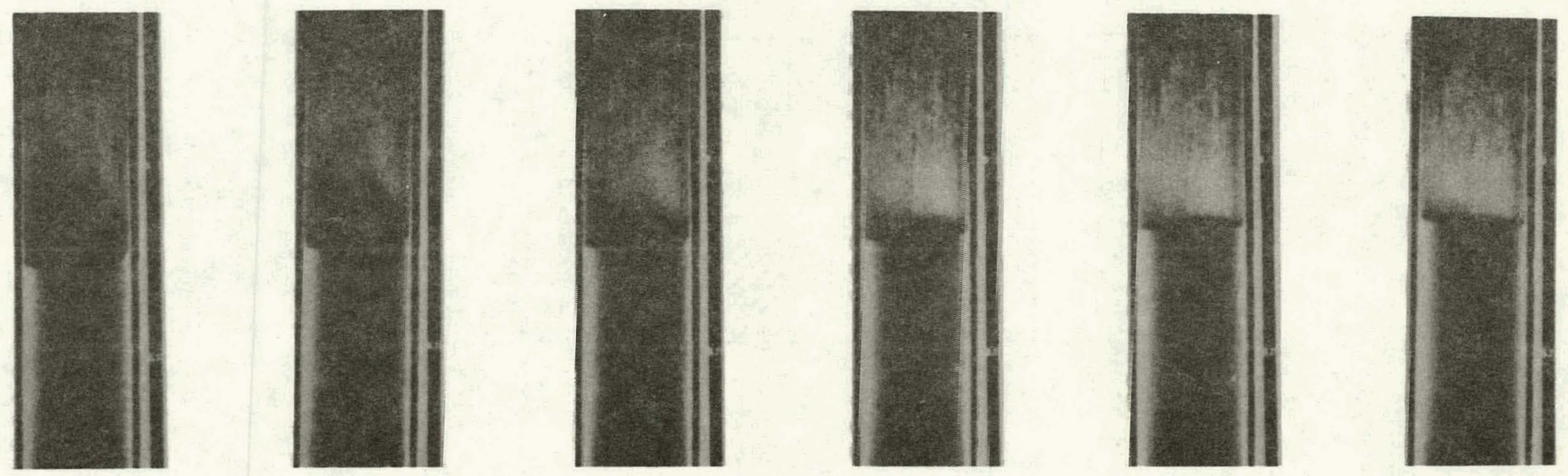

FIGURE 15. TYPICAL SEQJENCE FROM MOTION FICTURES OF THE FLUIDIZED BED MOCK UP (see Figure 14)

(tine interval $=0.375$ second: 
some of which have been already shown as Figures 12 and 13 . The bulk of this work appears in the first seven of the Quarterly Progress Reports (1). $\because$ Rather than to review all of this work, the major conclusions will be summarized with appropriate references given to the supporting data. As in any work of this type, considerable effort went into solving operational problems with the experimental equipment. That work will not be discussed except as 1 t relates to certain design features of the $50 \mathrm{MT} /$ year facility, e.g., vaporization of zinc. Such topics will be considered individually in later sections of this report.

\section{Effect of Reactant Throughput} and Particle Size

By going to a reactor outlet design which minimized inertial loss* of bed material to the exit line, and by using a graded-temperature bed (to be discussed later), the highest rate of deposition obtained was $344 \mathrm{~g} /$ hour on the seed particles in the 5-cm-dlameter reactor (Run No. 64), which (on an area basis) scales directly to $.25 \mathrm{MT} /$ year ( 80 percent on stream) in the 6.5-inch-diameter reactors that form the basis for the $50 \mathrm{MT} /$ year facility design. It is believed that the deeper beds in the larger units may lead to efficiencies** exceeding the 62 percent observed in Run 64: However, if the thermodynamically calculated efficiencles are valld, there may be limited room for improvement, as the conversion efficiencies of $\mathrm{SiCl}_{4}$ to silicon (bed $t$ wall + "dust") were cons1stently in the range of 285 to 95 percent of theoretical.

The above-referenced result was obtalned with a seed bed of $149 \mathrm{x}$ $297 \mathrm{\mu m}$ particles which increased in volume and bed depth by 96 percent during the run, 1.e., from an $L / D$ of 3.5 to 7 .

As distinguished from loss by elutriation.

* Fraction of silicon fed as silicon chloride that is collected on the seed particles. 
Subsequent runs (Nos. 69, 72, 78) with a 30. percent deeper starting bed on the average and with larger particleși, $279 \times 590 \mu \mathrm{m}$ corresponding to a net decrease in starting bed area of to $\$ 33$ percent of that used in the reference run (No. 64) noted above, the fraction of silicon product collected on the seed particles decreased to about 93 percent of that observed earlier, as the result of a 260 percent increase in the amount of inely divided silicon carried downstream, 1.e., from w8 percent to 114 percent. Another run with a shallower bed of the larger particles (equivalent to w18 percent. of the surface area of the reference run) resulted in even lower efficlency of collection of silicon on the bed particles.

The variation of efficlency with bed area discussed above and the fact that in early runs on the program (Nos. 8, 9, 11, 13) with the reactants diluted with 70 percent inert gas, the recovery of the product silicon on the bed particles was greatest, is consistent with the anticipated competition of heterogeneous deposition with gas-phase nucleation and growth. Clearly the. production of gas-phase nucleated material must be minimized for greatest economy and operability. A target of 2 percent of the silicon product as silicon dust has been established for the experimental facility with the probability that the system can accommodate considerably more.

Not only is the specific surface area of the bed important in its potential for limiting silicon dust formation, but in affecting the efficiency of deposition on the seed particles and limiting deposition on the reactor wall (assuming equal radial growth rate on all surfaces). These factors favor the use of small particles. However, permissible throughput decreases with particle size. Thus there will be an optimum bed particle size distribution as determined by initial seed size and the ratio of seed rate to production rate. These factors have not yet been established.

Fortunately the effect on overall efficiency of wall deposits will rapidly decrease with reactor scale up to where periodic chlorination of the accumulated material can be used to keep it in check. By contrast, gas-phase nucleation of solids is a volume phenomenon and unless a mechanism is available for capture of once-nucleated particles in a deeper bed of the same 
fluidization characteristics, such particles will be elutriated from the bed.

Thus their formation must be controlled regardless of reactor size.

Before leaving the subject of product collection efficiency and the relation to it of gas-phase nucleation, it should be noted that part, if not all, of the gas-phase nucleation observed may be due to misting of the zinc. The three-body collision reaction

$$
2 \mathrm{Zn}(\mathrm{g})+\mathrm{SICl}_{4}(\mathrm{~g})=\mathrm{S} 1(\mathrm{~g})+2 \mathrm{ZnCl}_{2}(\mathrm{~g})
$$

or the sequence

$$
\begin{aligned}
& \mathrm{Zn}(\mathrm{g})+\mathrm{SiCl}_{4}(\mathrm{~g})=\mathrm{SiCl}_{2}(\mathrm{~g})+\mathrm{ZnCl}_{2}(\mathrm{~g}) \\
& \mathrm{Zn}(\mathrm{g})+\mathrm{SiCl}_{2}(\mathrm{~g})=\mathrm{Si}(\mathrm{g})+\mathrm{ZnCl}_{2}(\mathrm{~g})
\end{aligned}
$$

should both be less rapid than

$$
2 \mathrm{Zn}(l)+\mathrm{SiCl}_{4}(\mathrm{ads})=\mathrm{Si}(\mathrm{s})+2 \mathrm{ZCl}_{2}(\mathrm{~g}) \text {. }
$$

Further, it has been demonstrated that silicon growth in a $\mathrm{SiCl}_{4}$ atmosphere is rapid on zinc droplets. Accordingly, the presence of zinc mist in the vapor should lead to silicon dust formation. Such zinc mist could be entrained by the zinc vaporization, or could result from condensation on cooling by insufficiently preheated $\mathrm{SiCl}_{4}$ or product-outlet purge gas. In this connection, it should be recognized that the amount of zinc condensation in the gas phase required to give the observed behavior would be miniscule. A $0.01-\mu \mathrm{m}$ zinc nucleus for each $1-\mu \mathrm{m}$ silicon particle would have required condensation of only 7.7E-6.percent of the zinc fed in a run from which an aspirated sample was taken. It is concluded that every effort should be made to avoid formation of zinc mist by condensation or by entrainment. 


\section{ZInc/21nc Chloride Condensation}

As Indicated in the Thermodynamic Analysis section of this report (F1gure 9), cooling of the reaction product tends to drive the reaction in the direction of generating more slifcon (klnetics permitting). This effect was observed in the early work on the program to have occurred to the extent of plugging the extt line from the fluidlzed-bed reactor. For that reason, It is necessary to maintain the temperature of the exit ine at or above the reactor temperature. Further, it may be expected that any zinc condensed in the presence of silicon tetrachloride would be coated with a chin fllw of silicon. It is belleved that this effect accounted for the sluggish flow of zinc condensate in the reactor exit until this IIne was maintained at a temperature equal to or exceeding that of the top portion of the fluldized bed so that no zinc condensed.

The necessity for quenching the reaction by-product is shown by the calculations of Table 13 which predict equilibrium liquid zinc condensation from $\sim 800 \mathrm{C}$ downward.

Experiments described in the Fifth/Sixth Quarterly Report(1) demonstrated the formation of sillcon crystallites (as well as submicron gasphase nucleated material) in the temperature range 730 to $930 \mathrm{C}$. Thus, if equilibrlum by-product condensation were allowed to occur, ample opportunity would exist for reduction of residual $\mathrm{SiCl}_{4}$ as predicted by the equilibrluin conversion of Figure 9 .

\section{Electrolytic Recovery of Zinc}

\section{From 2inc Chlorlde}

As discussed above, the electrolytic cell has two functions:

(1) To recover zinc and chlorlne from the zinc chloride by-product for recycle

(2) Chlorination of the particulate silicon that is suspended in the zinc chloride.

The first function has been demonstrated in the early work of Threlfall(16), Fray (32), and more recently by Haver, et al. (33), and Shanks, 
TABLE 13. EQUILIBRIUM CONDENSATION OF ZINC AND ZINC CHLORIDE FROM BY-PRODUCT GAS CONTAINING $30.45 \mathrm{~m} / 0 \mathrm{Zn}(\mathrm{g}), 41.85 \mathrm{~m} / 0$ $\mathrm{ZnCl}_{2}(\mathrm{~g}), 15.23 \mathrm{~m} / 0 \mathrm{~S}_{4} \mathrm{Cl}_{4}(8)$, and $2.47 \mathrm{~m} / 0$ INERT GAS

(Nominal $50 \mathrm{MT} /$ year facility by-product composition)

\begin{tabular}{llc}
\hline T, C & $\begin{array}{c}\text { Z1nc Condensed } \\
\text { cumulative percent }\end{array}$ & $\begin{array}{c}\text { zinc Chloride Condensed, } \\
\text { cumulative percent }\end{array}$ \\
\hline 827 & 0 & 0 \\
802 & $0(\sim$ dew point) & 0 \\
777 & 34.45 & 0 \\
752 & 56.49 & 0 \\
727 & 70.90 & 0 \\
702 & 80.40 & 0 \\
677 & 86.45 & 0 \\
652 & 96.98 & 86.65 \\
627 & 98.34 & 92.70 \\
602 & 99.01 & 95.88 \\
577 & 99.44 & 97.68 \\
552 & 99.64 & 98.68 \\
527 & 99.82 & 99.26 \\
502 & 99.87 & 99.62 \\
\hline
\end{tabular}


et al. (17), of the Bureau of Mines. However, the by-product of the present process differs from the zinc chloride used in the published work in that it contains unreacted $z$ inc and suspended silicon "dust". Thus 1 t became of Interest to verify the electrolysis of zinc chloride by-product and the chlorination of the contalned a111con.

The experimental electrolytic cell as inltially used with vertical electrodes is shown in F1gure 16. However, to avold loss of current efficlency due to rechlorination of deposited zinc, horlzontal electrodes were later used and the cell was nickel plated to reduce corrosion by the evolved chlorlne. Further, a syphon arrangement was subst1tuted for the bottomdelivery valve which was subject to malfunction: In accordance with the Bureau of Mines practice, $50 \mathrm{~m} / 0 \mathrm{KCl}$ was used in most runs to increase conductivity and to decrease $\mathrm{ZnCl}_{2}$ volatility.

Table 14 summarlzes the data obtalned in selected runs from which the following conclustons could be drawn.

(1) The minfplant by-product condensate can be electrolyzed to recover $z$ inc and chlorine from the contalned $\mathrm{ZnCl}_{2}$ without apparent interference (such as cell shorting) by the contained suspended zinc and silicon dust.

(2) S1l1con dust suspended in the by-product condensate can be chlorinated in the electrolytic cell at least up to 3.4 percent of the s111con production of the fluidized bed.

(3) Cell voltages were h1gher than those experienced by the Bureau of Mines work; this is belleved to relate partly to electrode resistance loss and perhaps to less efflclent mixing of the $\mathrm{ZnCl}_{2}$ with the $\mathrm{KCl}$ electrolytic inventory. Solution of this problem is being pursued.

In Table 15 are 11sted pertinent data on the history and projections for $\mathrm{ZnCl}_{2}$ electrolysis from which it can be concluded that a projected electrical energy requirement of about $2 \mathrm{kwh}$ per pound of zinc electrolyzed appears to be reasonable. 


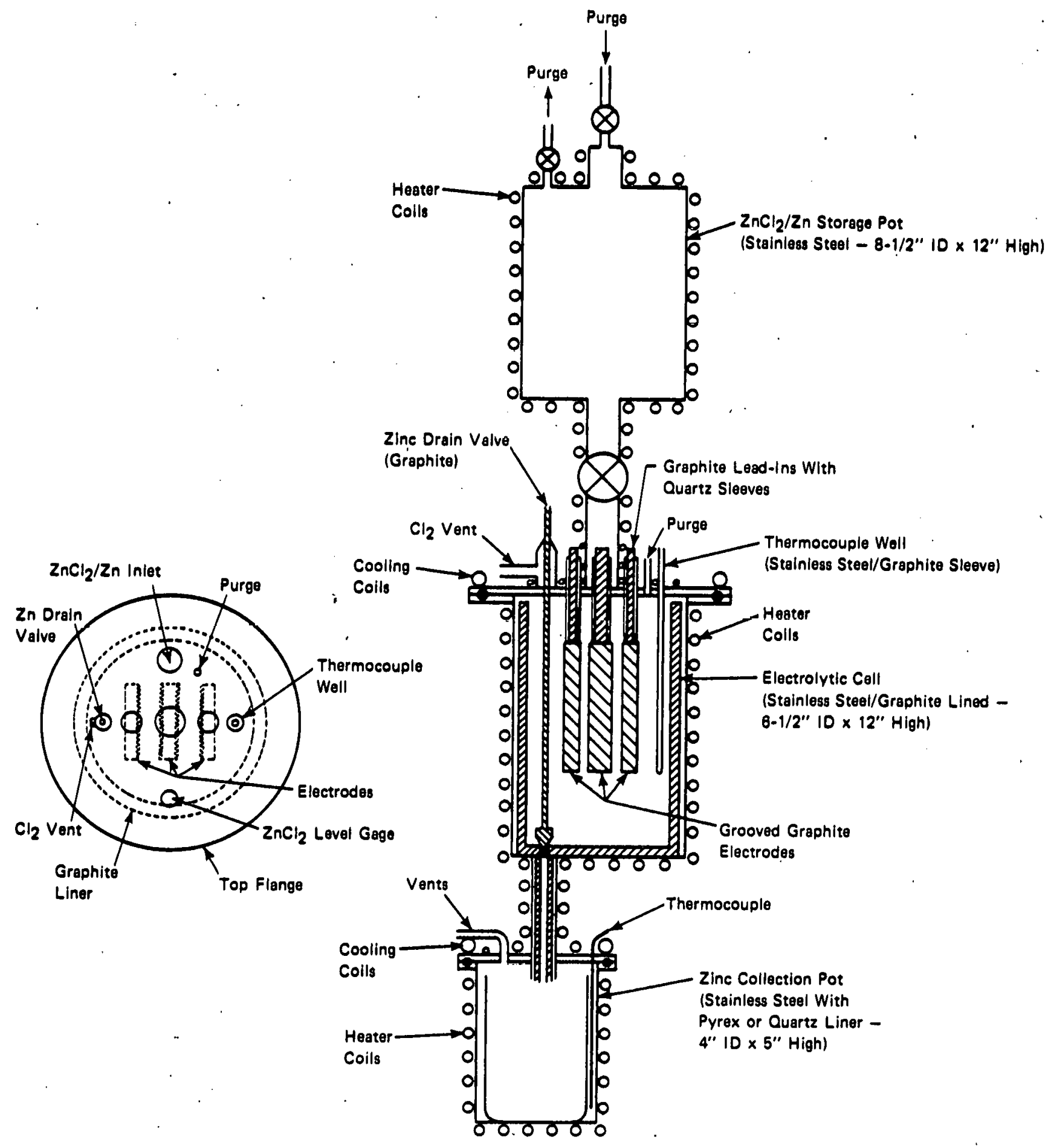

FIGURE 16. SCHEMATIC DIAGRAM OF EXPERIMENTAL ZINC CHLORIDE TO ZINC RECOVERY SYSTEM AS ORIGINALLY CONSTITUTED

(see text for modifications) 
TABLE 14. SURAART OF EXPERTMENTAL EIECTROLYSIS(a) OF $\mathrm{ZnCl}_{2}$ AT 500 C (SELECTED DATA)

\begin{tabular}{|c|c|c|c|c|c|c|c|c|c|c|c|}
\hline Run & $\begin{array}{c}\text { Cell } \\
\text { Configuration }\end{array}$ & Feed & $\underset{\text { app }}{1}$ & $\underset{a x p / c a}{1}$ & $\underset{\text { molts }}{\nabla}$ & $\begin{array}{l}\text { The, } \\
\text { hours }\end{array}$ & $\underset{\text { percent }}{\text { CE, }^{(b)}}$ & $\begin{array}{l}\text { PE, (c) } \\
\text { percent }\end{array}$ & $\mathbf{l} \mathbf{h} / \mathbf{1 b}$ & Renarios & $\begin{array}{l}\text { Quarterly } \\
\text { Report(1) } \\
\text { Reference }\end{array}$ \\
\hline $\mathbf{A}$ & $\begin{array}{l}\text { Verticle } \\
\text { electrodes }\end{array}$ & $\begin{array}{l}\text { Miniplant } \\
\text { condensate }\end{array}$ & 2140 & 0.8 & 415 & 45 & $80-108^{(d)}$ & 9-11 & 25.8 & $\begin{array}{l}\text { Lov pourer effi- } \\
\text { clency due to } \mathrm{high} \\
\text { realativity of } \mathrm{ZnCl}_{2}\end{array}$ & 7 \\
\hline B & $\begin{array}{l}\text { Hor izontal } \\
\text { electrodes } \\
\sim 125 \mathrm{~cm}^{2}\end{array}$ & $\begin{array}{l}\text { Synthet 1c } \\
\mathrm{ZnCl}_{2} ; 50 \\
\text { /o in } \mathrm{kCl}\end{array}$ & 100 & 0.8 & 5 & .21 & 76 & 22 & 2.5 & $\begin{array}{l}\text { Terninated by cell } \\
\text { overfiow due to } \\
\text { electronic level } \\
\text { indicator mallunction }\end{array}$ & 8 \\
\hline C & $\begin{array}{l}\text { Horizontal } \\
\text { electrodes (17) } \\
\sim 125 \mathrm{~cm}^{2}\end{array}$ & $\begin{array}{l}\text { Synthetic } \\
\operatorname{zncl}_{2} ; 50 \\
\text { /o In xCl }\end{array}$ & $\begin{array}{l}100 \\
150\end{array}$ & $\begin{array}{l}0.8 \\
1.2\end{array}$ & $\begin{array}{l}5 \\
8\end{array}$ & $\begin{array}{r}30 \\
6\end{array}$ & 61 & 17 & 3.4 & $\begin{array}{l}\text { Zinc non-coalescence } \\
\text { preaurably due to } \\
\text { poloture in } \mathrm{ZnCl}_{2}\end{array}$ & 9 \\
\hline D & $\begin{array}{c}\text { Horizontal } \\
\text { electrodes }(17) \\
2125 \mathrm{c}\end{array}$ & $\begin{array}{l}\text { Synthetic } \\
\text { 2nCl2; } 50 \\
\text { Jo in } \mathrm{XCl}\end{array}$ & 100 & 0.8 & 10 & 12 & 95 & 15 & 3.4 & - & - \\
\hline E & $\begin{array}{c}\text { Ulorizontal } \\
\text { electrodes(17) } \\
2125 \mathrm{~cm}^{2}\end{array}$ & $\begin{array}{l}\text { Hiniplant } \\
\text { condensate } \\
50 \mathrm{wo} \\
\text { In } \mathrm{kCl}\end{array}$ & $\begin{array}{l}100 \\
115 \\
250\end{array}$ & $\begin{array}{l}0.8 \\
0.9 \\
1.2\end{array}$ & $\begin{array}{l}29 \\
10 \\
12\end{array}$ & $\begin{array}{r}5 \\
10 \\
12\end{array}$ & 87 & 13 & 4.5 & $\begin{array}{l}\text { Suspended SI dust } \\
\text { chlorinated to } \mathrm{SICl}_{4} \\
\text { equivalent to } 3.4 \\
\text { percent of tintplant } \\
\text { product Si }\end{array}$ & $\mathbf{1 0}$ \\
\hline $\mathbf{F}$ & $\begin{array}{l}\text { Hortzontal } \\
\text { electrodes (17) } \\
2125 \mathrm{~cm}^{2}\end{array}$ & $\begin{array}{l}\text { Miniplant } \\
\text { condensate } \\
50 \mathrm{a} / \mathrm{o} \\
\text { In } \mathrm{KCl}\end{array}$ & 94 & $\begin{array}{r}0.8 \\
.\end{array}$ & 29 & 95 & 95. & $\begin{array}{r}16 \\
\cdots\end{array}$ & $\begin{array}{r}2.5 \\
\cdots\end{array}$ & $\begin{array}{l}\text { Bxcept for power } \\
\text { aupply ealfunction } \\
\text { run essentially } \\
\text { trouble-free }\end{array}$ & - \\
\hline
\end{tabular}

(a) Re-exantnation of data resulted in selected values which may differ from those given in Qwarterly Reports (1).

(b) Current efficleacy.

(c) Power efficlency.

(d) Composition of feed uncertain. 
TABLE 15. HISTORY AND PROJECTION OF $\mathrm{znCl}_{2}$ ELECTROLYSIS

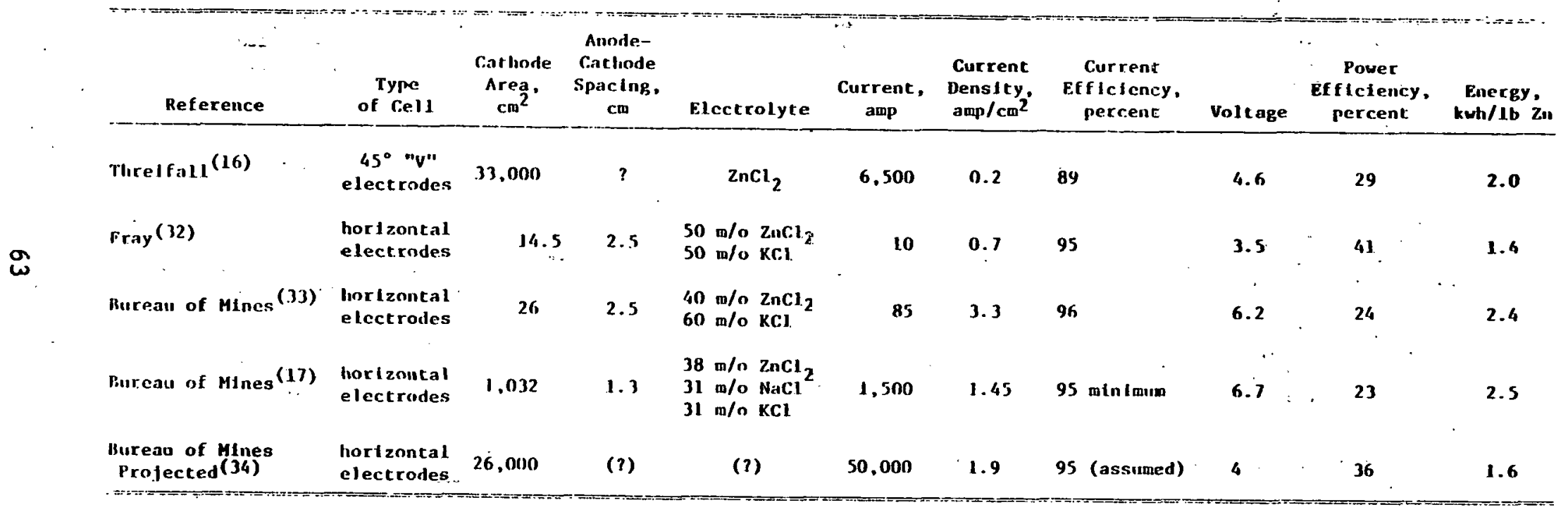




\section{Zinc Vaporization}

Although zinc is sufficiently volatile to be feasible as a reductant in the present process, the bolling temperature (908 C at 1 atm, $918 \mathrm{C}$ at $1.1 \mathrm{~atm}$, and $927 \mathrm{C}$ at $1.2 \mathrm{~atm})$ is high enough so that the prospect of monitoring flow rate by pressure drop across a sonic orffice is not attractive. This would require operating the boller at pressures appreclably above 2 atm, i.e., at bolling temperatures above $980 \mathrm{C}$.

The use of a flash vaporizer with a metered stream of liquid zinc was explored as an alternative. This arrangement had been used successfully in the miniplant, as pictured in Figure 13, with the vaporizer temperature at $1350 \mathrm{C}$. Although this flash vaporizer was marginally satisfactory on a small scale with quartz equipment, the prospect of scaling it up by a factor of 10 to provide the $1 / 2 \mathrm{~kg}$ of zinc per minute required for each of the two $25 \mathrm{MT} /$ year reactors of the projected $50 \mathrm{MT} /$ year facllity appeared to be formidable. In attempting to decrease the temperature of the flash vaporizer, it was found that the inventory of zinc in the vaporizer would have to be undesirably large, resulting in a hysteresis in zinc vapor flow following a change in the liquid feed rate. Although the heat-transfer coefficlent from graphite (the preferred liner material) to boiling zinc was found to be high ( $\left.450 \mathrm{BTU} / \mathrm{hour} \cdot \mathrm{ft}^{2} \cdot \mathrm{F}\right)$, zinc does not wet graphite, and a thick film (representing a significant inventory) is present on the heat-transfer surface. Detafls of the types of "flash" vaporfzers considered theoretically and experimentally are given in the Seventh, Eighth, and Ninth Quarterly Reports (1).

As none of the vaporizer designs considered were attractive, induction coupling of energy directly to the liquid zinc was explored. If the thermal capacity of the vaporizer and the degree of superheating can be minimized in a direct induction-coupled system, it should be possible to control the rate of vaporization by the energy input with a minimum of hysteresis. 
The Tenth Quarterly Report describes an experiment in which bolling rates of $1 / 2$ and 1 pound per minute of $z i n c^{*}$ were readily maintained in a horizontal vaporizer consisting of a quartz tube $57 \mathrm{~min}$ in diameter and $30 \mathrm{~cm}$ in length. To ald in inftial heating of the vaporizer (into which liquid zinc was metered) as well as to reduce the inventory and to decrease misting, the cross section of the tube was filled with 1/4- to 3/8-inch graphite chips. No attempt was made to control the rate of vaporization by energy input except to raise the energy input to the point that the vaporization rate (as measured by welghing the condensed zinc continuously) was equal to the liquid feed rate (as metered by displacement).

Subsequent contacts with Lepel, Inc., makers of the induction heating equipment, confirmed the feasibllity of controlling the vaporization rate by energy input. Lepel englneers are also considering the feasibility of sensing the zinc inventory in the vaporizer by its induction coupling - characteristics. Although that method of control may be desirable, it has been determined that the zinc level can be readily sensed by a simple electric contact consisting of a sheathed tungsten wire. Even if an impedance-based sensor were to be used, an electrical contact indlcator should probably be incorporated as a backup.

\section{Product Quality}

As mentioned earlier, the feasibility of preparing semiconductorgrade silicon by the zinc reduction of silicon tetrachloride has been demonstrated by DuPont, although improved uniformity of product appeared to be desirable and is thought to be attainable through the semicontinuous operation of this program. Most of the work with the miniplant has related to study of the process, in which case seed beds of crushed metallurgical-grade silicon were used for reasons of economy. However, several runs were made with seed of semiconductor-grade silicon crushed, leached and dried, and with semiconductor-grade silicon tetrachloride as the feed material. The zinc

* The 1 pound per minute being about that required by one of the $25 \mathrm{MT} /$ year units of the $50 \mathrm{MT} /$ year facility. 
was distilled zinc obtained in ingot form from Belmont S\&R, Inc. The zinc ingots were cleaned after machining by degreaing.

A total of $6.1 \mathrm{~kg}$ of product for quality evaluation has been forwarded to JPL. Some of this was as the product of single runs with seed contents ranging from 30 to 50 percent. However, late in the program, a serles of runs was made in which the product served as the seed for subsequent runs. In this way seed contents as low as 5.6 percent were obtalned. Table 16 summartzes the geneology and disposition of this material.

In some of the runs made in the minlplant for quality-evaluation purposee, the product was recovered after the bed had been purged (at operating temperature) to remove zinc vapor: Desplte thls precaution, some zinc condensate was observed on some of the particles. In other runis where a semicont1nuous product withdrawal aystem was used, zinc condensation occurred briefly in the particle withdrawal tube as discussed under the section of this report on Part1cle Dynamics.

The actual zinc content of the granular silicon sent to JPL for evaluation is uncertaln, spark source mass spectrometrlc analyses having ranged from 140 to 3000 ppaw. A serles of experiments is being run to determine (1) what part of the zinc is on the surface (e.g., as condensate), (2) what part has been entrapped in the growing granules, and (3) what part can be removed by a simple heat treatment. Further, JPL has submitted samples for neutron activation analysi's as will be discussed below.

The problem with analysis of as-produced particles by the spark source masa spectrometer 18 that only one or a few particles are "seen" In the analysis. As the particle-to-particle composition unfformity should be good during the growth process, one particle should be representative of the entire bed. However, in the matter of zinc condensed on the outer surface considerable Inhomogenlety might be expected.

With the obfective of eliminating contamination of surface-condensed zinc and whatever occluded zinc that might diffuse to the surface in vacuum heat treatment, the products of Runs Nos. 97 and 98 were heated for 1 hour at $920 \mathrm{C}$ In an evacuated quartz tube before sh1pment to JPI. In the course of this heat treatment, No. $97108 t 1090 \mathrm{ppm}$ of zinc and No. 98, $1280 \mathrm{ppm}$. 
TABLE 16. GENROLOGY AND DISPOSITION OF QUALITY EVALUATION PRODUCTS

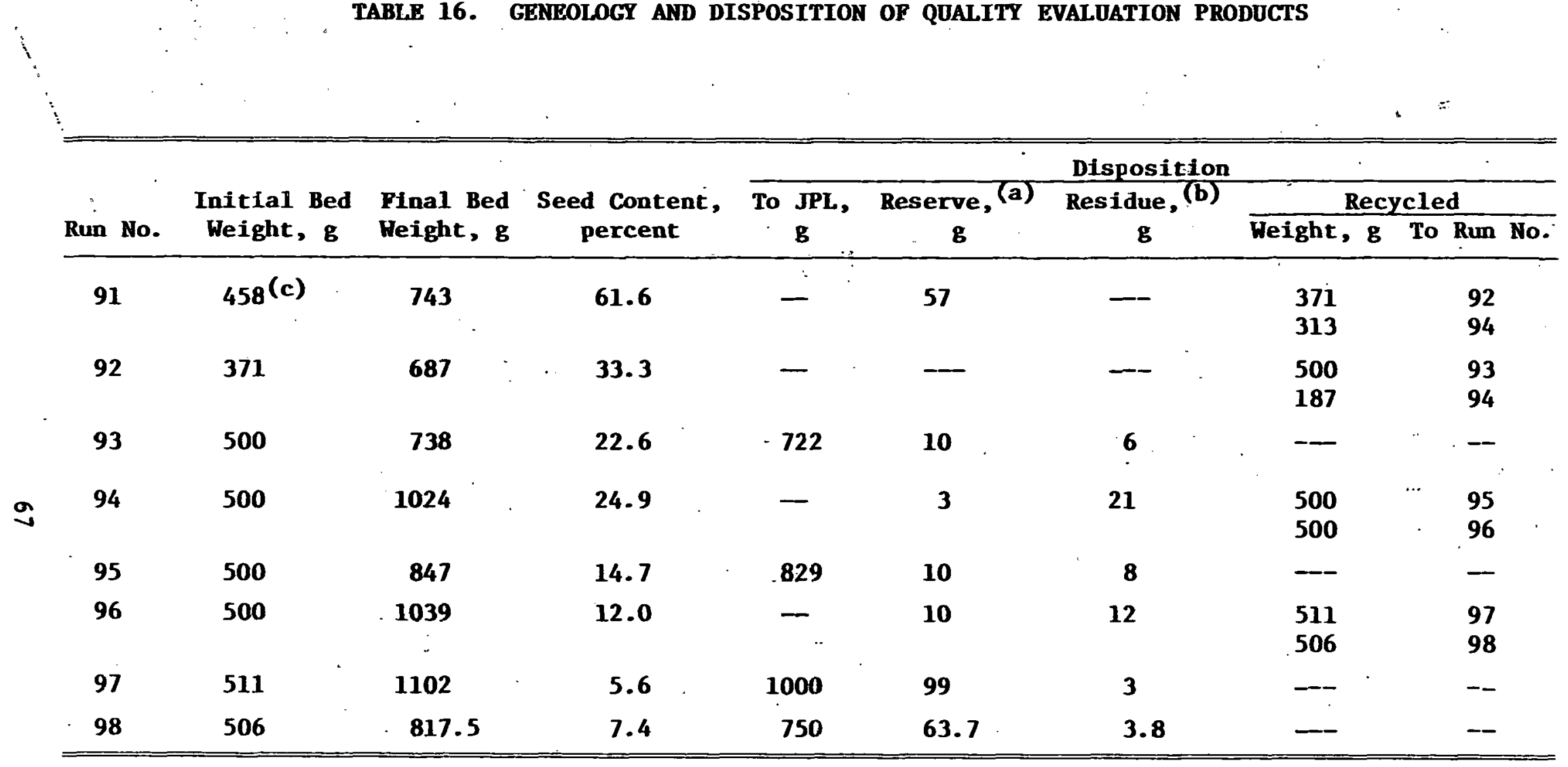

(a) Free flowing material, retained at BCL.

(b) Contaminated with zinc on withdrawal (see text), retained at BCL.

(c) 105- $x$ 149- $\mu$ m semiconductor-grade sillicon seed. 
With the possibility of surface contamination obviated, residual -zinc detected In subsequent analyses of these samples would thus be attributable to the bulk material.

Because of high volatility, it has not been possible to dope silicon with zinc in the work at Westinghouse/Dow Corning (35) and at Monsanto. (36). Thus, in any solar cell-forming process that involves melting silicon, residual zinc is expected to be evolved and a few thousand ppm may not be detrimental in the product fed to that melting step. To determine the loss of zinc on fusion of the silficon, two products, ine high and one low in 2 Inc, were melted and held molten at $21440 \mathrm{C}$ for 1 hour in vacuum and in a stream of gettered argon. The results are given in Table 17.

TABLE 17. REMOVAL OF ZINC FROM SILICON ON FUSION IN ARGON AND VACUUM

(1 hour, $1440 \cdot \mathrm{C}$, sample weight $2.5 \mathrm{~g}$ )

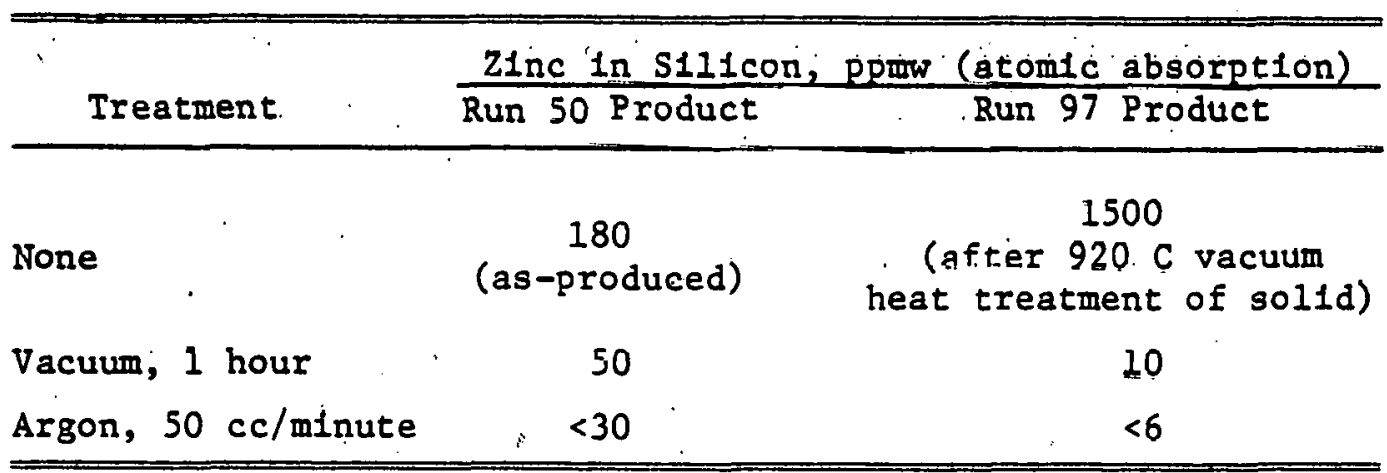

The $3 \ell$ of argon that was passed over the 2.5-g silicon sample is more than sufficient to account for removal of zinc from the 1500 to $6 \mathrm{ppm}^{\text {: }}$ level by the most conservative assumptions. The reasons for the discrepancles between the results of the argon purge and the vacuum treatment (which should be more effective) may be related to the presence of an oxide or nitride film on the slifcon, which although of insufficient thickness to be visible, would be expected to constitute and effective diffusion barrier for zinc removal 
at the surface. The effective purlty of the argon may have been higher than that of the vacuum.

It is evident that the zinc content of the product can be reduced to the ppm level or below by fuston of the silicon. Whether or not zinc removal is necessary remains to be determined. It is possible that the zinc content can be adequately reduced by heat treatment short of fusion.

The reason for the large difference in occluded zinc content between the products of Runs 50 and 97 is probably significant and will be studied.

Except for the question of contamination by surface-condensed zinc (which is removable by leaching ur vacuum heat treatment), the analysis for zinc is under control as indicated by the data of Table 18. Neutron activation and atomic absorption appear to give the most reliable analysis; however, the accuracy of the mass spectrometric analysis could undoubtedly be 1mproved by the use of standards.

TABLE 18. COMPARATIVE ANALYTICAL RESULTS, PPWW, FOR ZINC IN SILICON

\begin{tabular}{|c|c|c|}
\hline \multirow[b]{2}{*}{ Analytical Method } & \multicolumn{2}{|l|}{ Sample } \\
\hline & 97 & 98 \\
\hline Spark-source spectrometer, BCL & 3000 & 2000 \\
\hline Atomic absorption, BCL & 1500 & -- \\
\hline Neutron activation, LLL ${ }^{(37)}$ & & \\
\hline 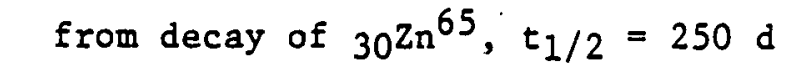 & $1480 \pm 12$ & $1519 \pm 12$ \\
\hline from decay of $30^{2 n^{69}}, t_{I / 2}=13.8 \mathrm{~h}$ & $1469 \pm 12$ & $1517 \pm 12$ \\
\hline
\end{tabular}

Comparison of mass spectrometric (SSMS) and neutron activation (NA). analyses for other elements is made in Table 19.

. For those elements not listed as "<" (inconcluslve) the SSMS analyses are reasonably consistent with the NA analyses for $\mathrm{Zn}$ and $\mathrm{Sb}$ but not for $\mathrm{Na}$ and $W$. 
TABLE 19. COMPARATIVE ANALYSES OF SILICON PRODUCTS, PPWW

\begin{tabular}{|c|c|c|c|c|}
\hline \multirow[b]{2}{*}{ Element } & \multicolumn{2}{|c|}{ Run 97} & \multicolumn{2}{|c|}{ Run 98} \\
\hline & $\operatorname{SSMS(8)}$ & $\mathrm{NA}(\mathrm{b})$ & SSMS(a) & $\mathrm{NA}(\mathrm{b})$ \\
\hline $\mathrm{Na}$ & 4 & $0.0004 \pm 0.0003$ & 20 & $0.002 \pm 0.0017$ \\
\hline Cr & $<3$ & $(0.3 \pm 0.3)(c)$ & $<3$ & $i .(0.2 \pm 0.2)(c)$ \\
\hline $\mathrm{Fe}$ & $<3$ & $(5 \pm 5)$ & $<3$ & $1(3.6 \pm 3.6)$ \\
\hline$N 1$ & $<5$ & $(25 \pm 25)$ & $<1$. & $:(26 \pm 26)$ \\
\hline Co & $<3$ & -- & $<3$ & $0.024 \pm 0.006$ \\
\hline $\mathrm{Cu}$ & $<7$ & $4.4 \pm 0.5$ & $<7$. & $1.4 \pm 0.3$ \\
\hline $2 \pi(d)$ & 3000 & $1480 \pm 12$ & 2000 & $1319 \pm 12$ \\
\hline $\mathrm{Zn}^{(e)}$ & 3000 & $1469 \pm 12$ & 2000 & $1517 \pm 11$ \\
\hline $\mathrm{Ga}$ & $<1$ & $0.009 \pm 0.007$ & $<1$ & $0.009 \pm 0.008$ \\
\hline As & $<0.1$ & $0.043 \pm 0.003$ & $<0.1$ & $0.035 \pm 0.002$ \\
\hline $2 r \stackrel{(q)}{ }$ & $<1$ & $(12 \pm 12)$ & $<2$ & $(12 \pm 12)$ \\
\hline $2 x^{(g)}$ & $<1$ & $(3.5 \pm 3.5)$ & $<2$ & $(3.4 \pm 3.4)$ \\
\hline Mo & $<1$ & $(0.7 \pm 0.7)$ & $<1$ & $(0.6 \pm 0.6)$ \\
\hline A8 & $<2$ & $2.4 \pm 0.1$ & $<1$ & $0.85 \pm 0.08$ \\
\hline$s b(h)$ & 4 & $3.10 \pm 0.02$ & 2 & $0.810 \pm 0.007$ \\
\hline$s b(1)$ & 4 & $2.96 \pm 0.04$ & 2 & $0.83 \pm 0.03$ \\
\hline La & $<0.1$ & $0.0047 \pm 0.0003$ & $<0.1$ & $0.0040 \pm 0.0004$ \\
\hline $\mathrm{Ta}$ & $<2$ & $0.025 \pm 0.005$ & $<6$ & $0.411 \pm 0.009$ \\
\hline $\mathrm{W}$ & 0.4 & $0.016 \pm 0.003$ & 0.4 & $0.023 \pm 0.002$ \\
\hline Au & $<0.1$ & $0.0008 \pm 0.0004$ & $<0.2$ & $0.0005 \pm 0.0001$ \\
\hline
\end{tabular}

(a) SSMS - spark source mass spectrometer, BCL.

(b) NA - neutron activat1on, LIL(37)

(c) Parenthetical values Indicate "that nuclide was not detected above beckground.

(d) NA v1a $2 n_{65}^{65}$.

(e) NA v1a $2 n^{69}$.

(f) NA v1a $2 x^{95}$.

(g) NA via $2 r^{97}$

(h) NA v1a Sb122.

(1) NA v1a Sb124. 
The sodium in the SSMS analysis is believed to come from the high-purity graphite used to form an electrode of the silicon granules by compaction, or from contamination. The reason for the difference in tungsten values is not clear.

For what it is worth, the SSMS analyses show 0.02 ppmw ( 0.06 ppma) boron in the products of Runs 97 and 98 . However, because of the possibility of contamination as in the case of sodium, confirmation by other methods or comparison with uncontaminated standards is necessary before these values can be taken seriously.

The significance of the elements for which the neutron activation analys1s appears to give meaningful results w1ll be studied as additional data are obtained.

In terms of bulk properties, the granular product is free flowing, with the particles becoming more nearly spherical as shown in Figure 17 which compares the product of Run 64 containing about 50 percent residual seed with that of Run 97 containing 5.6 percent residual seed.

The density of the as-produced particles approaches theoretical as indicated by the density measurements shown in Table 20 .

TABLE 20. DENSITY OF SILICON PRODUCT*

\begin{tabular}{lcc}
\hline \multicolumn{1}{c}{ Material } & Particle Size, $\mu \mathrm{m}$ & Density, $\mathrm{g} / \mathrm{cm}^{3}$ \\
\hline $\begin{array}{l}\text { Silicon } \\
\begin{array}{l}\text { Run No. } 97 \text { Product } \\
(5.6 \text { percent seed) }\end{array}\end{array}$ & $400-600$ & 2.33 (theoretical) \\
& $\begin{array}{l}\text { Corrected }(-0.3 \text { percent) for } \\
\text { assumed } 1500 \text { ppmw } \mathrm{Zn} \\
\text { Density, percent of theoretical } 99.6\end{array}$ \\
\hline \hline
\end{tabular}

* Pycnometric density (xylene) measured with granular material. 


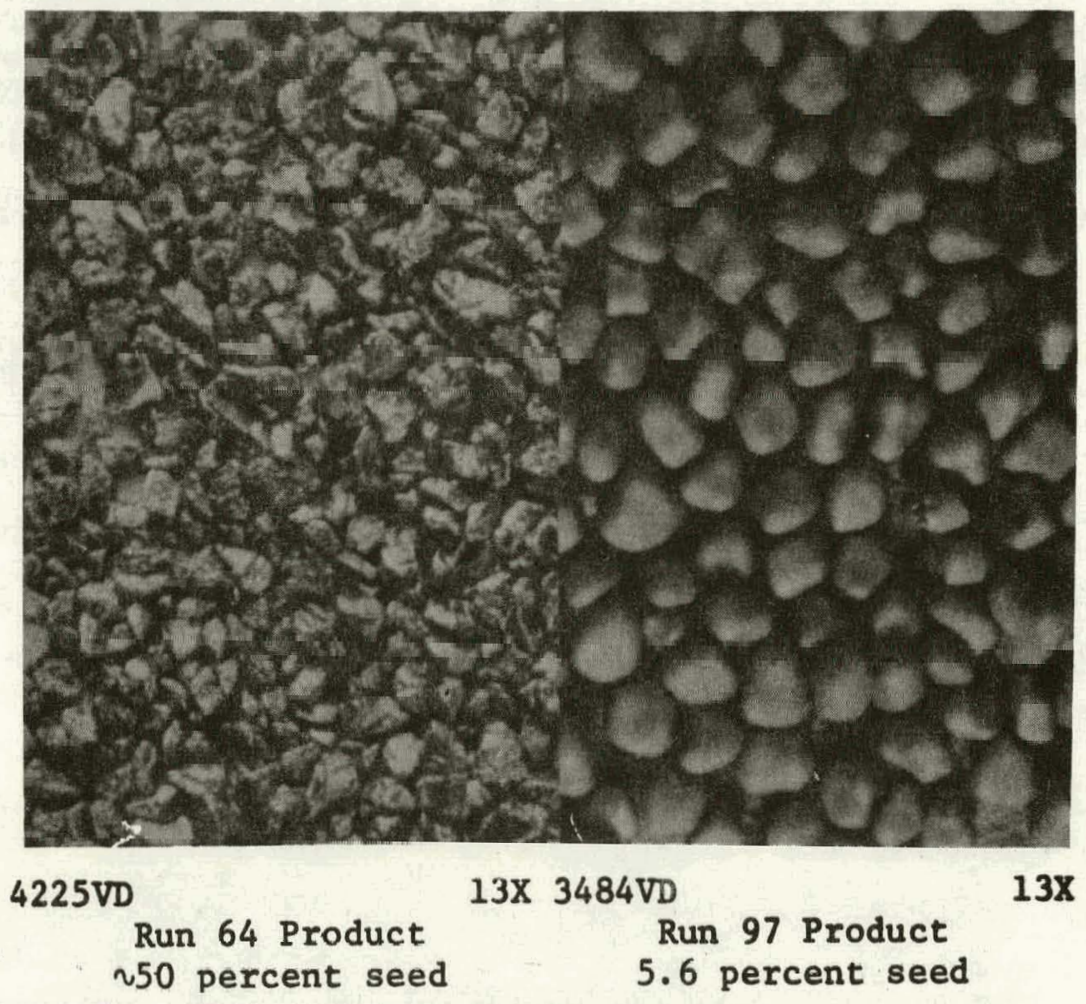

FIGURE 17. COMPARISON OF AS-PRODUCED PARTICLES INDICATING INCREASED SPHERICITY WITH DECREASED SEED CONTEN'T 
The near-theoretical density of the product is evident from the scanning electron micrograph of a fractured particle from Run No. 36 (Figure 18), in which very few voids are seen. The deposited silicon appears between the two markers.

A new scanning electron micrograph is being installed at BCL with which much higher resolution will be available than was available for taking the micrograph of Figure 18. It will be of interest to see if porosity at a higher level of dispersion can be detected. A mottled appearance developed on etching a polished particle cross section suggests that possibility.

\section{Seed Preparation}

To provide seed material for the runs to produce quality-evaluation samples, semiconductor-grade silicon was crushed in a hammer mill*, yielding about 50 percent in the desired particle size range of 149 to $420 \mu \mathrm{m}$.

Screening the seed was done on stainless steel screens with the solder seams and brass rims coated with epoxy to prevent contamination from those materials. Following screening, the seed was treated for 24 hours in $\mathrm{HF}$ and 24 hours in 50 percent $\mathrm{HF}-\mathrm{H}_{2} \mathrm{SO}_{4}$ with intermittent agitation, and then washed with deionized water and dried.

Spark-source mass spectrometric analyses of the milled and leached material were compared to those of the semiconductor-grade starting material. For all elements analyzed (74), the leached material was as good or better than the starting material.

* Dedicated hammer mill. 


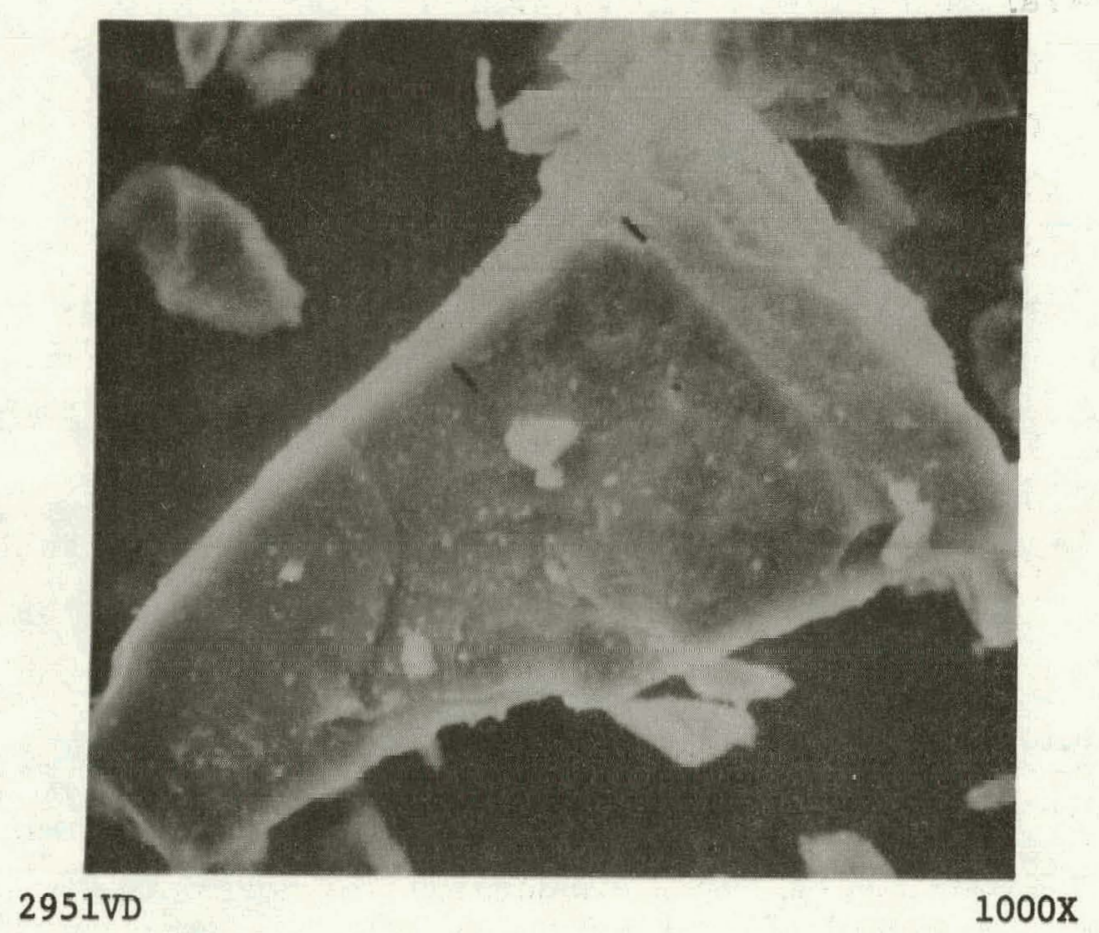

FIGURE 18. SCANNING ELECTRON MICROGRAPH OF FRACTURED PARTICLE FROM RUN 36 SHOWING ABSENCE OF APPRECIABLE POROSITY IN COATING BETWEEN MARKERS 


\section{50 METRIC TON PER YEAR}

EXPERIMENTAL FACILITY

For purposes of large-scale feastbil1ty study and refinement of cost est1mates, the design of a $50 \mathrm{MT} /$ year faclifty was inltiated. Contingent upon continued fevorable Indications of technical and economic feasibility, bullding, debugging, and operating the faclifty at BCL are contemplated as Phases III, IV, and $V$, respectively, of the present program.

Several objectives would be served:

(1) Confirmation of technical feasibility

(2) Conflrmation of economic feasib1l1ty

(3) Refinement of des1gn

(4) Demonstration and refinement of operation

(5) Proviston of larger quantities of representative product to ald in meeting the materials requirements of the LSA and other programs

(6) Provision of a base for the transfer of technology to commercial interests.

.- Three organizations have cooperated in formulating the design of the $50 \mathrm{MT} /$ year facllity. The $\mathrm{S1Cl}_{4}$ purification system was the primary responsibli1ty of Pace Englneers, Inc. (Pace), of Houston, Texas; the remalnder of the more conventional aspects of the design was handled by Raphael Katzen Associates International, Inc. (RKAII), of Cinc1nnat1, Oh10; and the less conventional aspects of the design and 1 ts overall integration were handled by BCL in cooperation with RKAII.

As the full design, submitted to JPL in early Apr11, 1978, for the1r consideration, represents a large package, it is difficult to report in detall without reproducing the package. The design package is referred to as Reference 38.

Accordingly, a few of the most significant drawings are reproduced here with explanatory notes so that the current status of the program may be 
appreciated by the reader. It is recognized that the drawings contain some detall that may not be legible at the scale used here; however, they are belleved to be sufficiently informative for the present purpose. In the interest of continulty, some of the material cited earlier in this report is repeated.

\section{$50 \mathrm{MT} /$ Year Si Facility Design}

In general, the procejo provides for mixing purtfied stlicon terrachloride and zinc vapor in the lower part of a fluldized bed of silicon seed particles on which the reaction product accumulates as a relatively dense and adherent deposit. The by-product zinc chloride vapor and unreacted zinc vapor are condensed and routed to electrolytic cells for recovery and recycle of the zinc. The unreacted silicon tetrachlorlde is recycled to the purification unit. In a production plant, the chlorine from the zinc chloride electrolysis would be used to produce the make-up silicon tetrachloride by reaction with metallurgical-grade silicon or with silicon carblde; however, In the experimental facility, it was deemed prudent to bypass this step, since silicon tetrachloride is readily avallable at a reasonable cost. Further, when the chlorination slep is eventually undertaken for minimizing overall cost, the design can be based on well-established practice, which needs no verification in the experimental facllity consldered here. AccordIngly, the chlorine from the electrolytic cells is converted to sodium hypochlorite for use locally in treating sewage plant effluent. The chlorineto-hypochlorite conversion system is integrated in the waste treatment section of the facility with a system for neutralizing and disposing of the waste silicon tetrachloride from the purification system.

Table 21 lists the major des1gn parameters of the $50 \mathrm{MT} /$ year S1 experimental factlity. It is to be noted that two $25 \mathrm{MT} /$ year fluidized-bed units nominally of 6.5-inch ID are used for flexibility and as a reasonable scale-up from the 2-inch ID reactor used in the miniplant. Although the nominal design is for $6.5-1$ nch $(16.5-\mathrm{cm})$ diameter, final cholce will probably be for somewhat larger, e.g., 7-1nch $(17.8-\mathrm{cm})$ dlameter. The capacity of 
TABLE 21. DESIGN PARAMETERS - $50 \mathrm{MT} /$ YEAR

SILICON EXPERIMENTAL FACILITY

- On-stream factor

- $\mathrm{Zn} / \mathrm{SICl}_{4}$ stolchlometry

- Reaction temperature

- Operation pressure

- Conversion of $\mathrm{SiCl}_{4}$

- Production rate

- Seed requirement (5 percent)

- Fluldized-bed reactors (two)

- $\mathrm{SICl}_{4}$ purification by distillation

- Zinc recycle by electrolysis

- Zinc recovery

- $\mathrm{Cl}_{2}$ disposal
80 percent

$2 / 1$

927 C (1700 F)

1 atm above fluidized bed

63 percent per pass

$7.20 \mathrm{~kg} /$ hour ( $15.87 \mathrm{lb} / \mathrm{hour}$ ) (16.8 $\mathrm{g} /$ hour $/ \mathrm{cm}^{2}$ cross section)

$0.36 \mathrm{~kg} /$ hour ( $0.79 \mathrm{lb} /$ hour)

16.5-cm (6.5-1nch) diameter

92 percent center cut

S1x 5000- to 6000-amp cells

95 percent

Conversion to $\mathrm{NaOCl}$ 
each unit, $3.6 \mathrm{~kg} /$ hour, is a direct scale-up on an area basis from the $340 \mathrm{~g} /$ hour production level attalned in the miniplant untt. The 63 percent $\mathrm{SICl}_{4}$ conversion per pass is a projection of miniplant experience; however, the seed requirements ( 5 percent of production) and the zinc recovery (95 percent) estimates are somewhat arbitrary at this polnt and subject to modification by experience.

As the Initial basis of deslgn, RKAII and Pace were provided with waterlals and energy flow sheets of the type shown in Table 22: The veralon given in Table 22 was the last revision (October, 20, 1977) in that format. Subsequent changes were made v1a the des1gn package ${ }^{(38)}$ as 1 progressed. A major difference between Table 22 and the final design was the substitution of $\mathrm{NaOH}$ nelieralization of the waste $\mathrm{SICl}_{4}$ for the $\mathrm{Ca}(\mathrm{OH})_{2}$ neutralization which was thought at the time to be more economical. Integrating the $\mathrm{SlCl}_{4}$ waste disposal, and chlorine to hypochlor1te 1mproves the overall design. Other less fundamental changes from the October 20, 1977, verston were made as the design proceeded, and are reflected in the discussion that follows.

In the discussion that follows, the process is divided into three sections -- Feed Preparation, Reaction and Recovery, and Waste Treatment.

\section{Feed Preparation}

"F1gure 19 shows the feed preparation section of the fac1l1ty, with process flow rates tabulated at upper left. S1l1con tetrachlorlde of the approximate analysis given in Table 23 is recelved in 40,000-pound tank trucks. This material is purfifed by distillation in two column (11ght-end and heavy-end) w1th intermediate surge tank (T101 in the f1gure). A 92percent center cut 18 taken, w1th 4 percent each of tops and bottoms $801 n g$ to waste. The purffied product from the top of the heavy-ends column goes to a feed tank that supplies each of the $\mathrm{SICl}_{4}$ bollers for the two $25 \mathrm{MT} / \mathrm{year}$ S1 fluldized-bed units. As shown in Figure 19, the pure $\mathrm{SICl}_{4}$ storage tank 1s compartmentalized (tentatively in $s 1 x$ sections) to permit independent qualification of lots of $\mathrm{SICl}_{4}$ before comnltting them to use: N1trogen $1 \mathrm{~s}$ iprovided to allow the varlous units to breathe to a vent system, the $\mathrm{SICl}_{4}$ 
TABLE 22. MATERIAL AND ENERGY FLOH SHEET (BNGLISH UNTTS) $50 \mathrm{MT} /$ YEAR SILICON FACULITY (Revised 10/20/77)

$[+\rightarrow=$ materials in or out; $(l)=$ liquid phase $]$

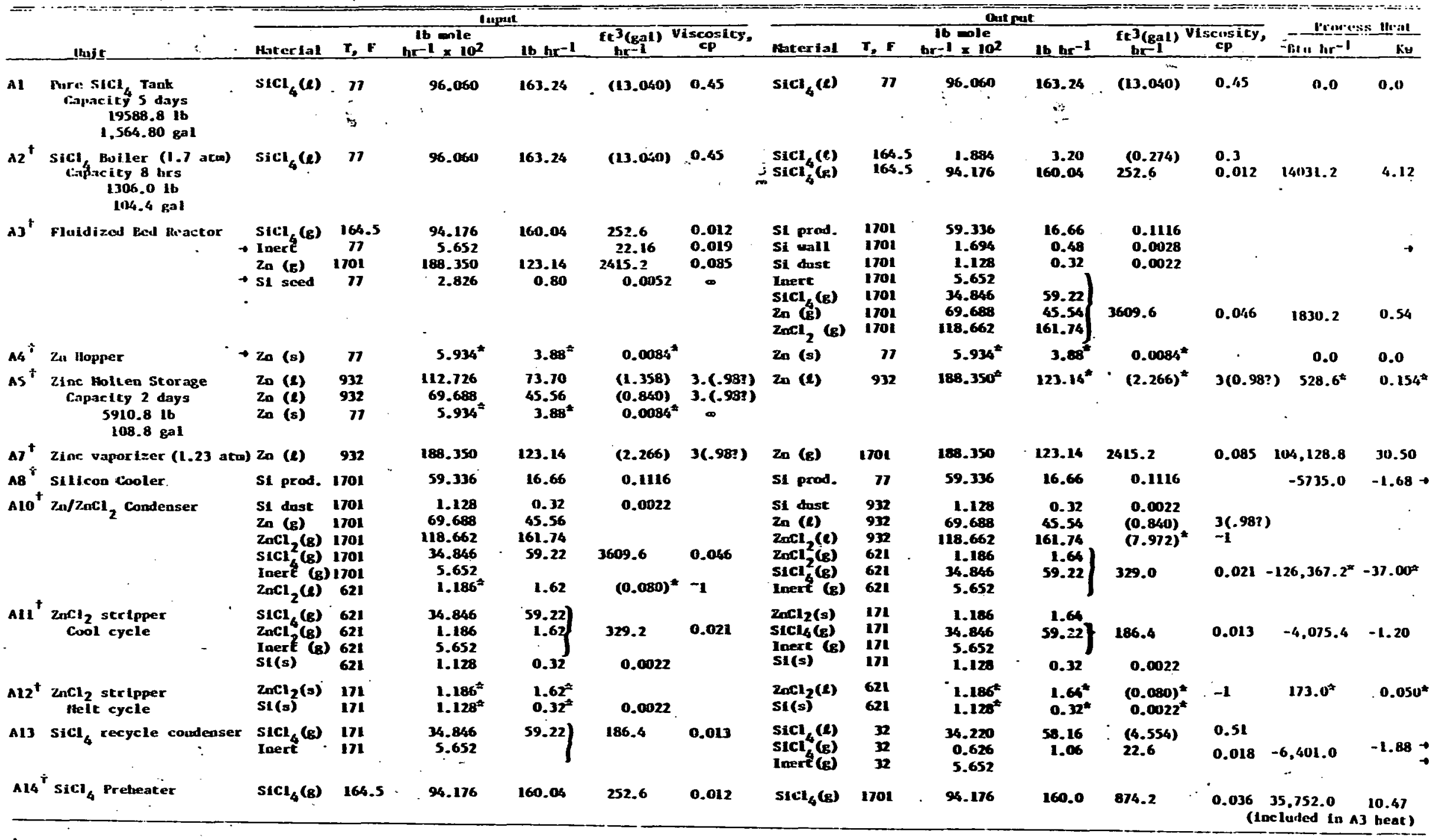

- Average of intermitteut operatlon.

t Total of duplicate mits. 
TABLE 22. (Continued)

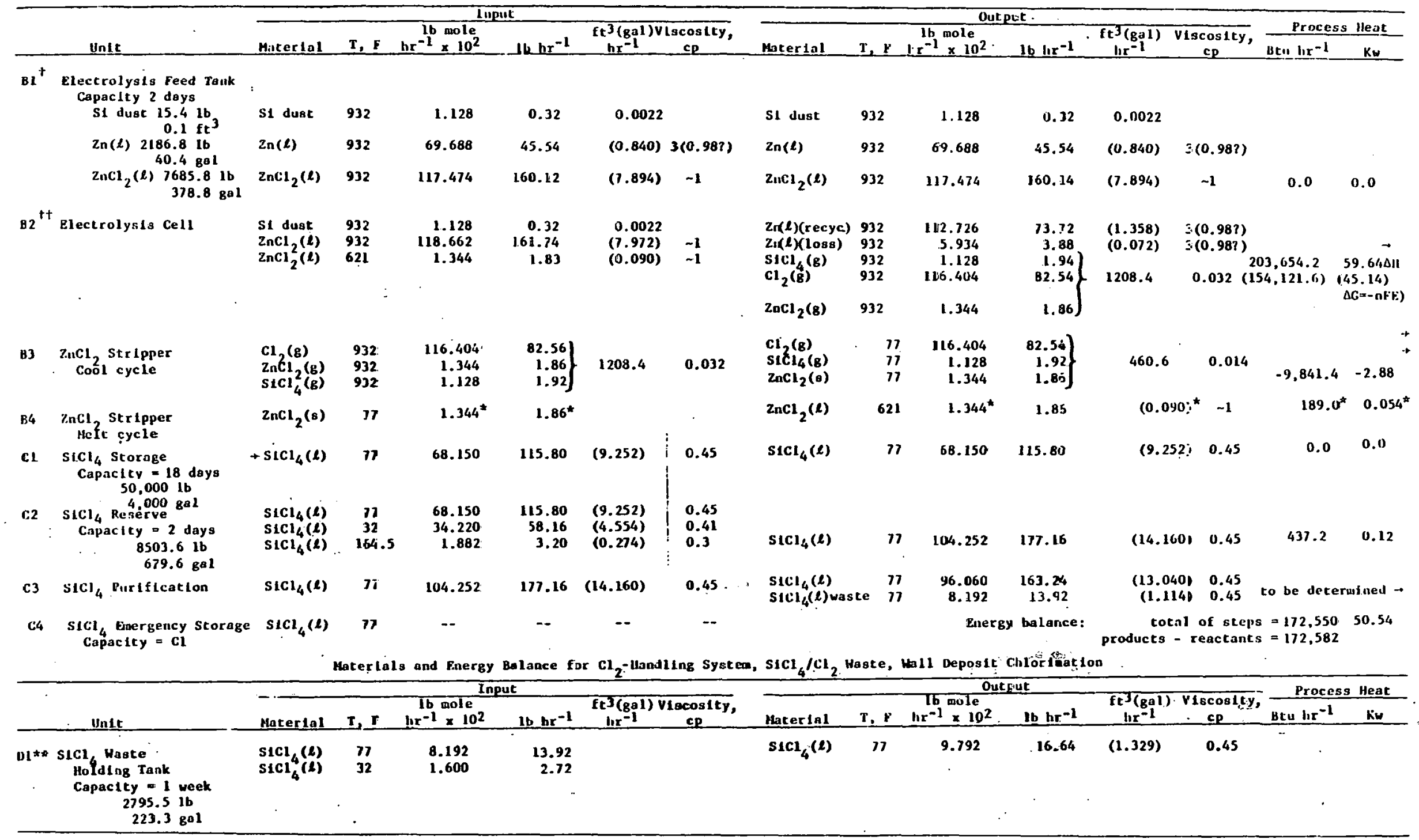

* Average of interwittent operation.

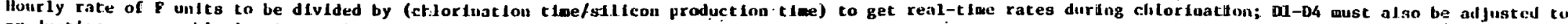
pruduction versus clslorination real tlme values.

$t$ Total of duplfcate unlts.
tt Total 
TABLE 22. (Continued)

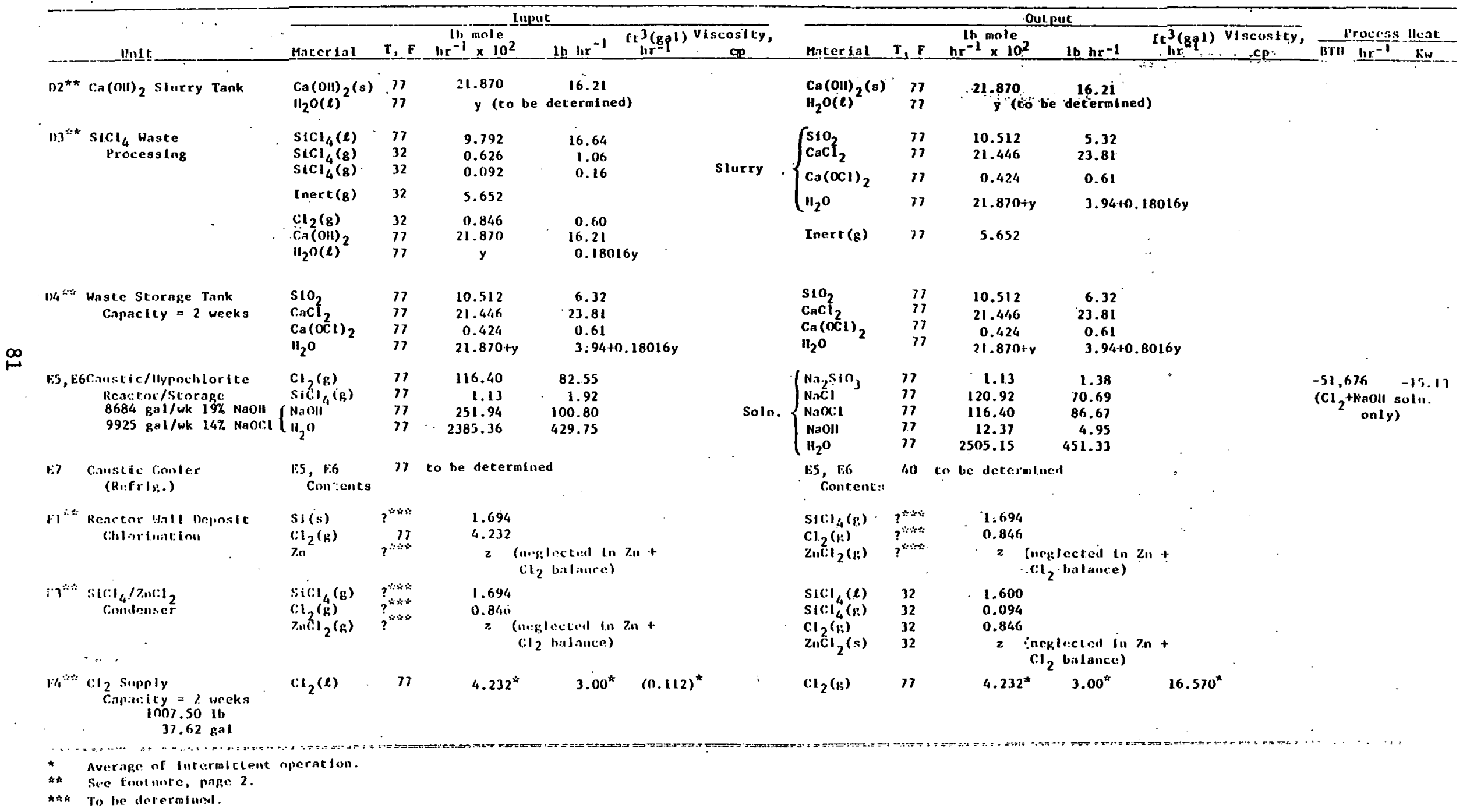




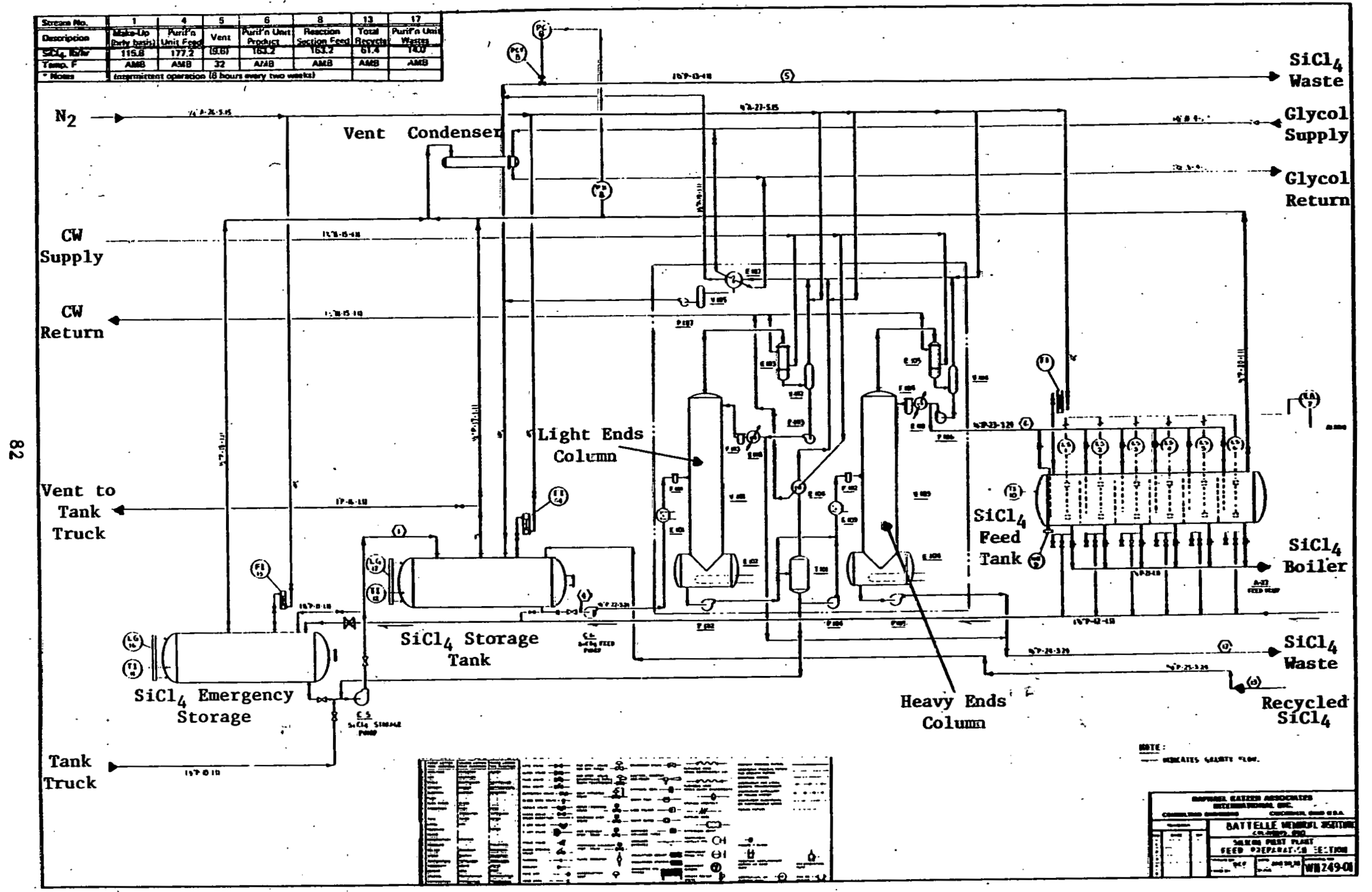

FIGURE 19. FEED PREPARATION 
TABLE 23. $\mathrm{SICl}_{4}$ COMPOSITION

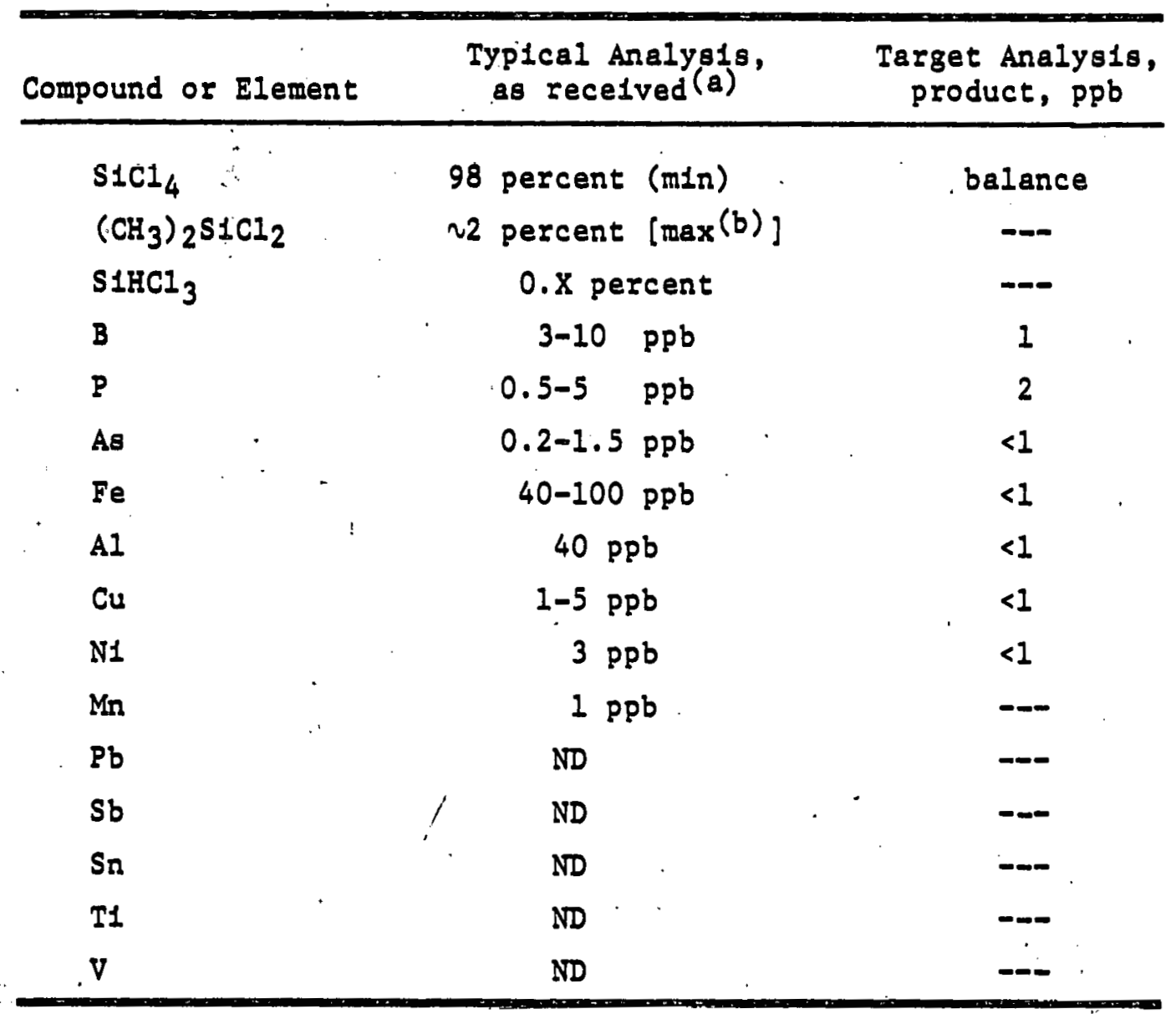

(a) Grade A160, Union Carb1de Company, S1stersville, Weat Virginia.

(b) Controllable to lower levels by avolding cross product contamination in loading and shipping. 
condensate from wh1ch goes to waste. An emergency atorage tank 1s provided so that the contents of units containing apprectable quantities of $\mathrm{SICl}_{4}$ can be conventently drained if necessary. The 1ndividual compartments of the pure $\mathrm{SICl}_{4}$ feed tank can be drained to the $\mathrm{SICl}_{4}$ storage tank for repur1f1cation or to the $\mathrm{SICl}_{4}$ emergency storage tank as desired.

The feed preparation section is designed to operate at pressures of up to 60 pg18.

\section{Reaction and Recovery}

Flgure 20 shows the reaction and recovery section of the facllity with process flow rates tabulated at upper left.

Purlfied $\mathrm{SICl}_{4}$ from the feed preparation section is held at constant level (pumped from storage) and constant pressure (power 1nput-controlled) In the $\mathrm{SICl}_{4}$ boller from where it is metered by gas-flow control into a preheater in the bottom section of the fluldized bed. Provision is made to Introduce an Inert gas at this point to purge the product withdrawal line. This addition will also avold the problems 1nherent in systems containing all condensible vapors. A proportionate flow control provides for continuously; bleeding part of the boller contents to storage to prevent impurity bulld-up.

The $\mathrm{SICl}_{4}$ vapor entering the bed $1 \mathrm{~s}$ met by an approximately sto1ch10metric* quantity of zinc vapor. The silicon product grows on s1llcon particles Introduced as seed from the hopper shown atop the reactor adjacent to a sight port: The granular product is withdrawn from the bottom of the reactor at a rate equal to the production rate [controlled by maintenance of constant bed level (pressure-drop monitored)].

Provision is made to periodically chlorinate the fraction of the silicon that deposits on the fluldized bed wall so as not to have excessive butld-up.

* As noted earlier in this report (Table 12), calculations have shown no economic advantage in deviating from stolchiometry. Further, the incidence of gas-phase-nucleated silicon tends to be increased on the zinc-rich side. 
The zinc/zinc chlorlde component of the by-product is condensed in a large condenser/heat exchanger (to be discussed later) and flows through an electrolysis feed tank into a bank of electrolysis cells (to be discussed later). In the design version shown in F1gure 20, the $\mathrm{S1Cl}_{4}$ /inert gas component of the by-product is passed through alternately cooled (for condensation) and heated (for melt-down) $\mathrm{znCl}_{2}$ strippers, and then through a slycol-cooled condenser to remove $\mathrm{SICl}_{4}$ for recycle. A simplification of the design has since been made providing for use of a single $\mathrm{ZnCl}_{2}$ stripper operating fust above the melting point and which will allow the small amount of $2 \mathrm{nCl}_{2}$ that escapes to condense (as a slurry) with the $\mathrm{SICl}_{4^{\circ}}$.

An organic heat exchange fluld, Thermino ${ }^{*}$, is used to maintain proper temperature levels for condensation in the large $\mathrm{Zn} / \mathrm{ZnCl}_{2}$ condenser and $\mathrm{ZnCl}_{2}$ strippers, and for melt-down of the $\mathrm{ZnCl}_{2}$ strippers.

Condensed $21 n c$ and $\mathrm{ZnCl}_{2}$, containing small quantities of suspended s111con "dust"**, flows from the electrolys1s feed tank (provided with a load cell for content monitoring) to one or more of the electrolytic cells (to be discussed later). The Ilquid zinc entering the electrolytic cells plus that produced by electrolysis of the $\mathrm{ZnCl}_{2}$ is withdrawn to the zinc storage tank by an overflow system whose helght is chosen to prevent overflow when the zinc has dropped to where (st111 above the submerged outlet) the head of $\mathrm{ZnCl}_{2}$ (controlled via a level indicator) is insufficlent to cause flow. Prevention of accumulation of impurities from the zinc is accomplished by periodic manual skimming of the $z$ Inc or $\mathrm{ZnCl}_{2}$ content of the electrolytic cells. Zinc: from the load-cell-monitored zinc storage tank is fed by gravity to a constant level tank that feeds the zinc vaporizer. The zinc vaporfzer (to be discussed later) is induction heated, directly coupled to the 21 in so that the vaporization rate can be controlled by power input. It is posstble that the zinc Inventory in the vaporizer can be monftored by the current-voltage relationship in the induction heater with the constant level device as back-up.

* Monsanto Industrial Chemical Company.

** Gas-phase-nucleated silicon that does not accumulate on the seed particles. 


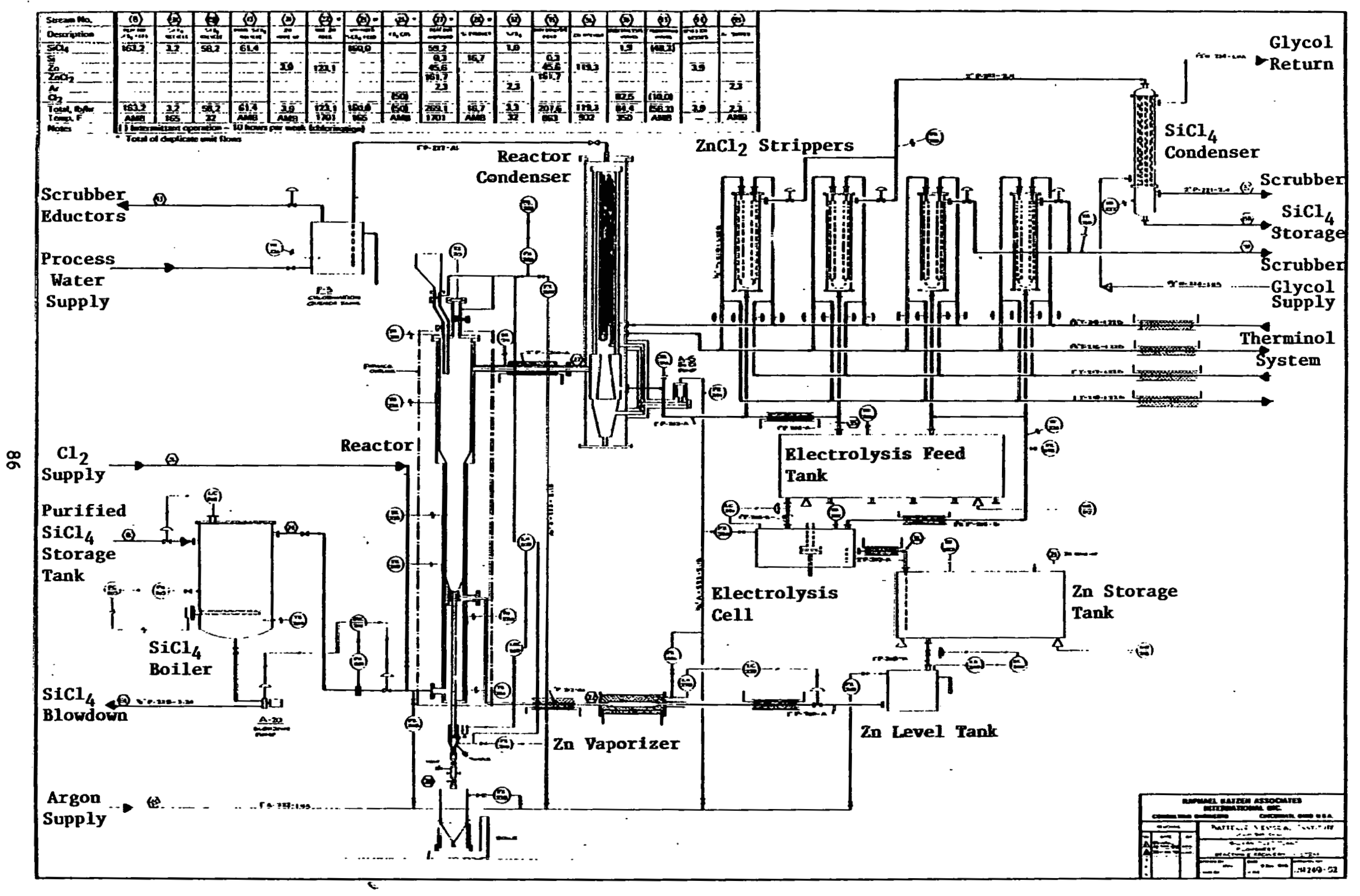

FIGURE 20. REACTION AND RECOVEKY 
Provistons are made for approprlate pressure equalization and venting of the reaction and recovery system.

\section{Waste Treatment}

The waste treatment section of the faclilty shown in Figure 21 has two primary functions: (1) to convert the chlorine from the electrolytic cells to hypochlorite that can be disposed of in local sewage treatment and (2) to neutrallze and dilute the $\mathrm{SiCl}_{4}$ waste (tops and bottoms from dist1llation and vented $\left.\mathrm{SICl}_{4}\right)$.

In removing the heat of reaction between chlorine and $\mathrm{NaOH}$ to form hypochlorite, air cooling of the hypochlorite has been combined with scrubbing of the alr from the plant area in the large unit, E7, termed the Area/Vent Gas Scrubber. This scrubber is provided with two sets of perforated trays over which solution is recirculated in two respective loops. The bottom loop contains 1 percent $\mathrm{NaOH}^{*}$ and the top loop, essentlally 19 percent $\mathrm{NaOH}$ as $1 t$ comes from the Caust1c Storage Tank, E6. The solution in the bottom loop circulates across the trays and through one of two interchangeable $e^{* *}$ eductors (E8) where it meets and reacts with the chlorine from the electrolytic cells to form hypochlorite solution. The $\mathrm{NaOH}$ concentration in the lower loop is maintained at 1 percent by demanding overflow from the top (19 percent NaOH) 10op. The net hypochlorite solution production is pumped out of the lower loop and into the Hypochlorite Storage Tank as controlled by a constant level device. A flow of outside and/or inside air through the Area/Vent Gas Scrubber cools the hypochlorite solution. Chlorine lost by volatilization from the lower trays is reabsorbed by the 19 percent $\mathrm{NaOH}$ in the upper 10op. An exhaust blower, E9 ( $10,000 \mathrm{cfm}$ ), in the scrubber exit is used to move the ait through the trays.

Neutralization of the $\mathrm{SiCl}_{4}$ wastes is taken care of in the system on the left of Figure 21. A solution of 2 percent NaOH circulates.through the

\footnotetext{
* Equivalent to 14 percent NaOCl.

** Duplicates provided to allow for cleaning of accumulated hydrated $\mathrm{S}_{2} \mathrm{O}_{2}$. from $\mathrm{SiCl}_{4}$ hydrolysis.
} 


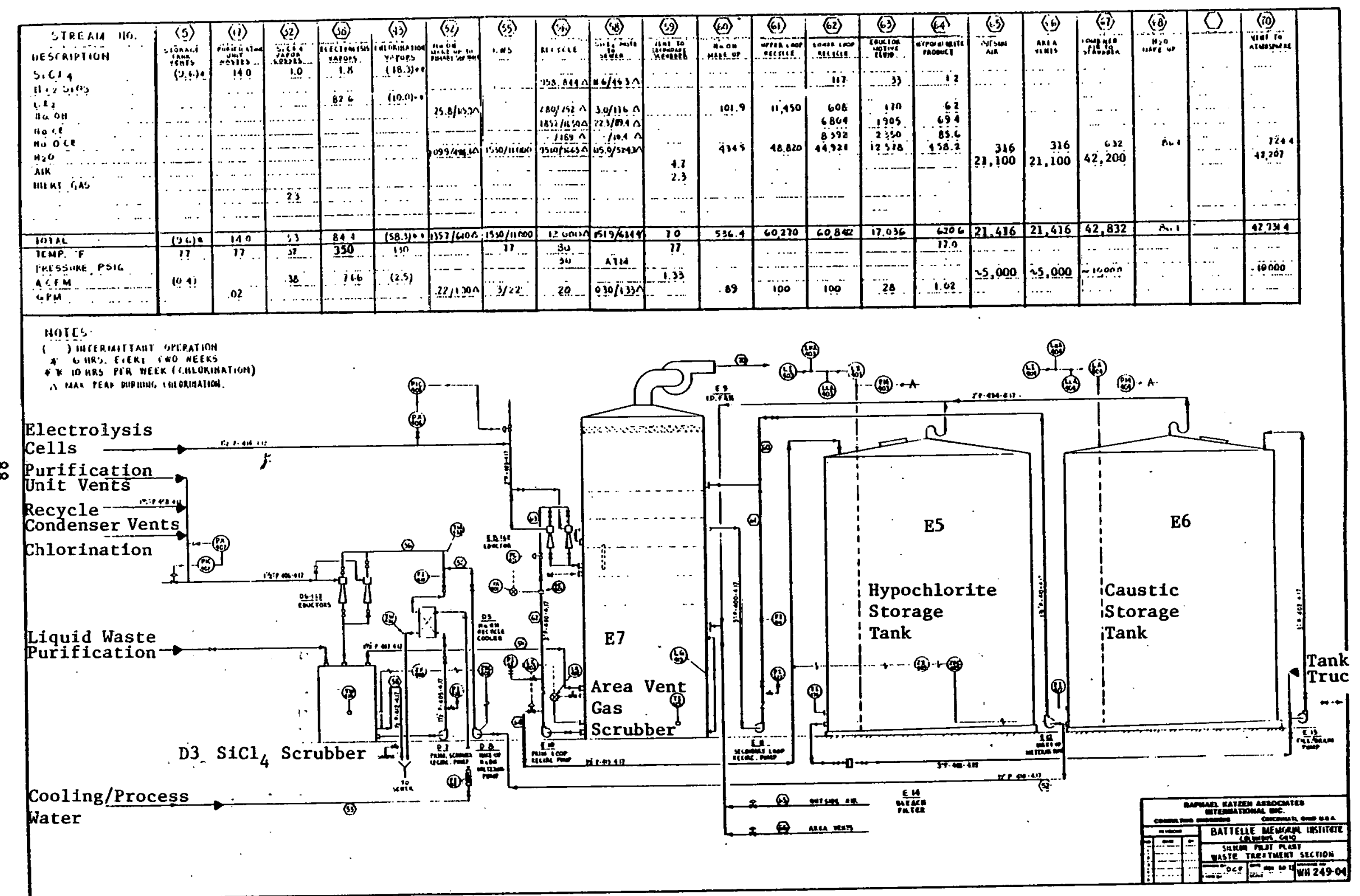

FIGURE 21. WASTE TREATMENT 
$\mathrm{SICl}_{4}$ Scrubber, D3, where the liquid $\mathrm{SiCl}_{4}$ wastes are neutralized. $\mathrm{SiCl}_{4}$ vapors in the vent gases are fed to one of a pair of interchangeable eductors, D6, through which the 2 percent $\mathrm{NaOH}$ solution circulates as the motive fluid. The net discharge from the $\mathrm{SiCl}_{4}$ scrubbing system ( $0.3 \mathrm{gpm}$ ) overflows to the sewer. No environmental problems should be caused by this amount of material, particularly since it will be heavily diluted with cooling water (e.g., 10/1) from the rest of the facllity.

The heat of the neutralization of the $\mathrm{SiCl}_{4}$ is dissipated in a watercooled exchanger, D5 ( $\mathrm{NaOH}$ Recycle Cooler). The capacity of this exchanger Is chosen to provide for the increased load during the periodic chlorination of silicon from the reactor walls.

\section{Fluldized-Bed Reactor}

Figure 22 shows the fluidized-bed reactor in greater detail than in Figure 20. $\mathrm{SiCl}_{4}$ vapor enters at the bottom, is preheated in the graphitegranule-packed annulus, and enters the fluidized bed through outer ports in the round-bottom distributor plate. Zinc vapor at just ahove its boling point (918 C at $1.1 \mathrm{~atm}$ ) enters the bed through a ring of inner ports in the distributor plate.

The fluidized-bed reactor is constructed of silicon-carbide-coated graphite or solid silicon carblde, encased in a No. 310 stainless steel shell provided with bellows to accommodate thermal expansion differentials.

Changes in the posttions of the $\mathrm{SiCl}_{4}$ inlet and reaction product outlet relative to the flxed zinc vapor inlet and the connecting equipment are accommodated in the assembly sequence and by means of appropriate slip joints in non-critical positions.

The graphite is rendered impervious by appropriate coating to avoid deleterious exposure of the stainless steel shell to zinc vapor. Tungsten coating of the stainless steel is being studied as additional protection. 


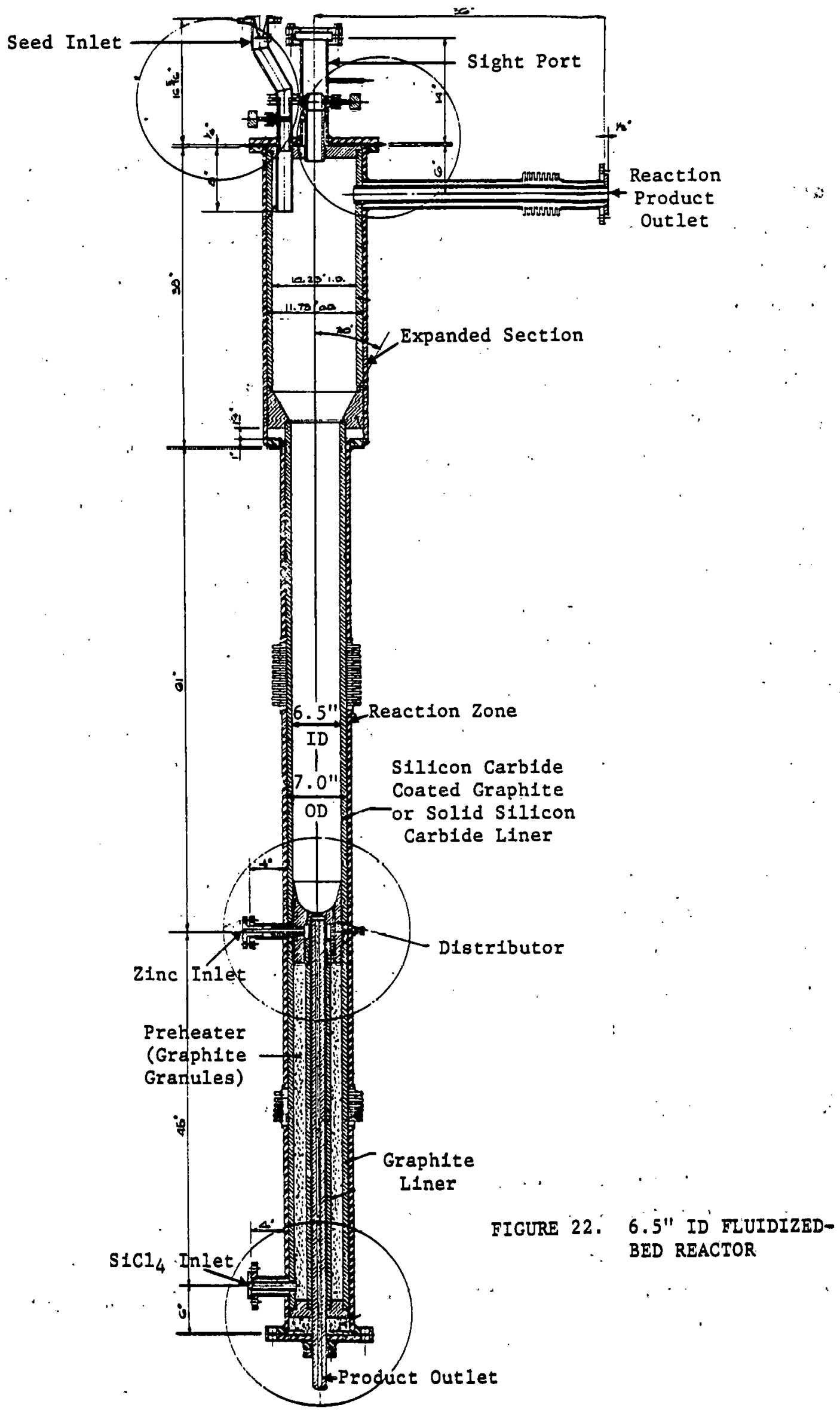




\section{Zinc Vaporizer}

As discussed in an earlier section of this report, one of the more difficult aspects of the facility design has been the problem of supplying the high heat of vaporization of zinc while maintaining a limited zinc vaporizer. Inventory to minimize hysteresis in the vaporlzer output response. To drive the heat of vaporization through graphite or silicon carbide requires bulky equipment, steep temperature gradients, and excessive $z$ inc inventory. This problem has been solved by direct induction. coupling to the zinc in a quartz vessel. The zinc vaporizer design (w1thout blowdown, Figure 23) is parcerned after the vaportzer tested experimentally.

The vaporizer is packed with graphite chips to facilitate heating before Ilquid zinc is added and to reduce the inventory of zinc in the vaporizer per unit effective volume. Carbon wool is contalned in the compartment formed by a wier placed 4 inches from the exit end, to act as a demister for the zinc' vapor. Entrained droplets of unvaporized zinc not only serve to carry over impurities, but they act as nucleation and growth sites for silicon needles and powders, which can escape deposition on the seed particles of the fluidized bed. The zinc vapor line is lagged with heaters unt1l well inside the fluldized bed furnace, to prevent condensation of $z$ inc.

It is planned that the zinc vaporization rate be controlled by power Input, and although present plans call for constant level control based on electrical contact level sensing, it is posstble that the liquid zinc inventory in the vaporizer can be sensed by the current-voltage relationship in the converter, and the latter used for control with the electrical contact retalned as backup.

\section{Zinc/Zinc Chlorlde Condenser}

As indicated in the general description above, the reaction product conststs of $\mathrm{ZnCl}_{2}$ vapor, unreacted $z 1 \mathrm{nc}$ and $\mathrm{SICl}_{4}$ vapor, a small amount of entrained gas-phase-nucleated s111con powder, and inert purge gas. The condenser, shown in two sectional views at right angles in Figure 24, provides 
Transite Water Pipe Class 100

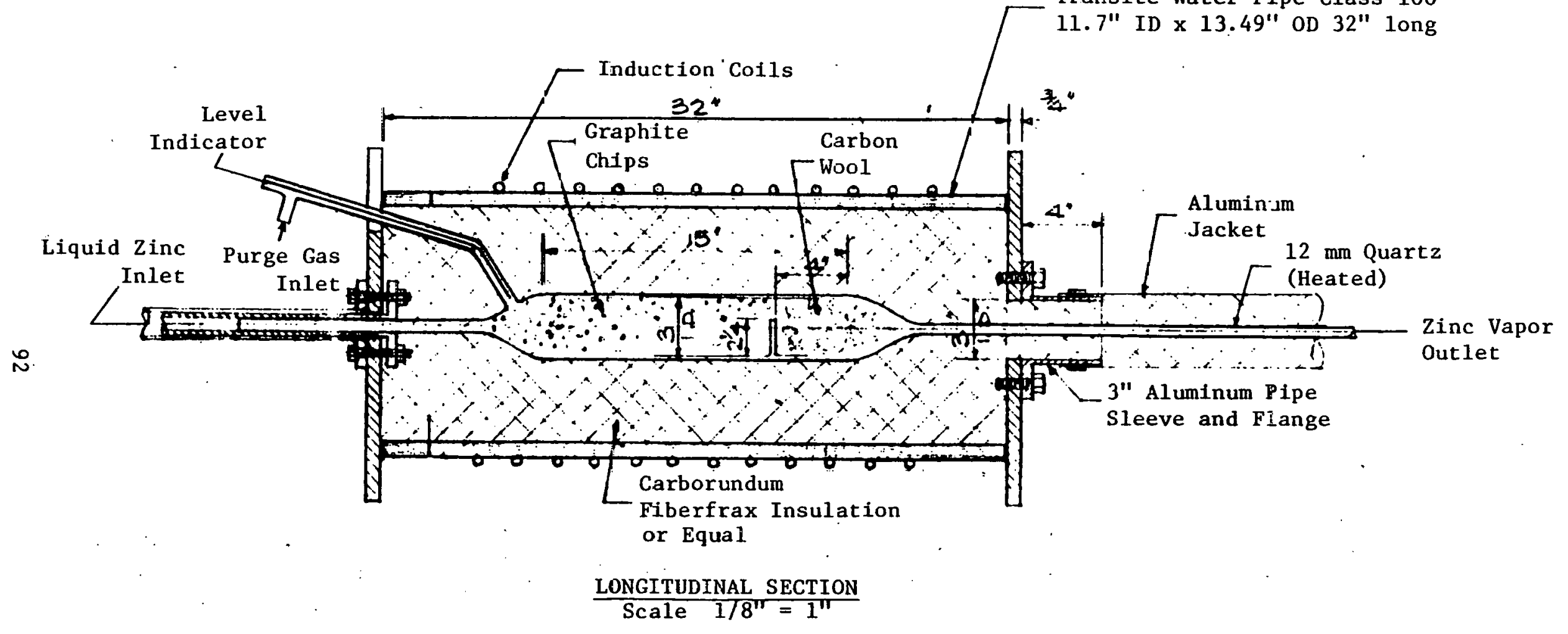

FIGURE 23. ZINC VAPORIZER 

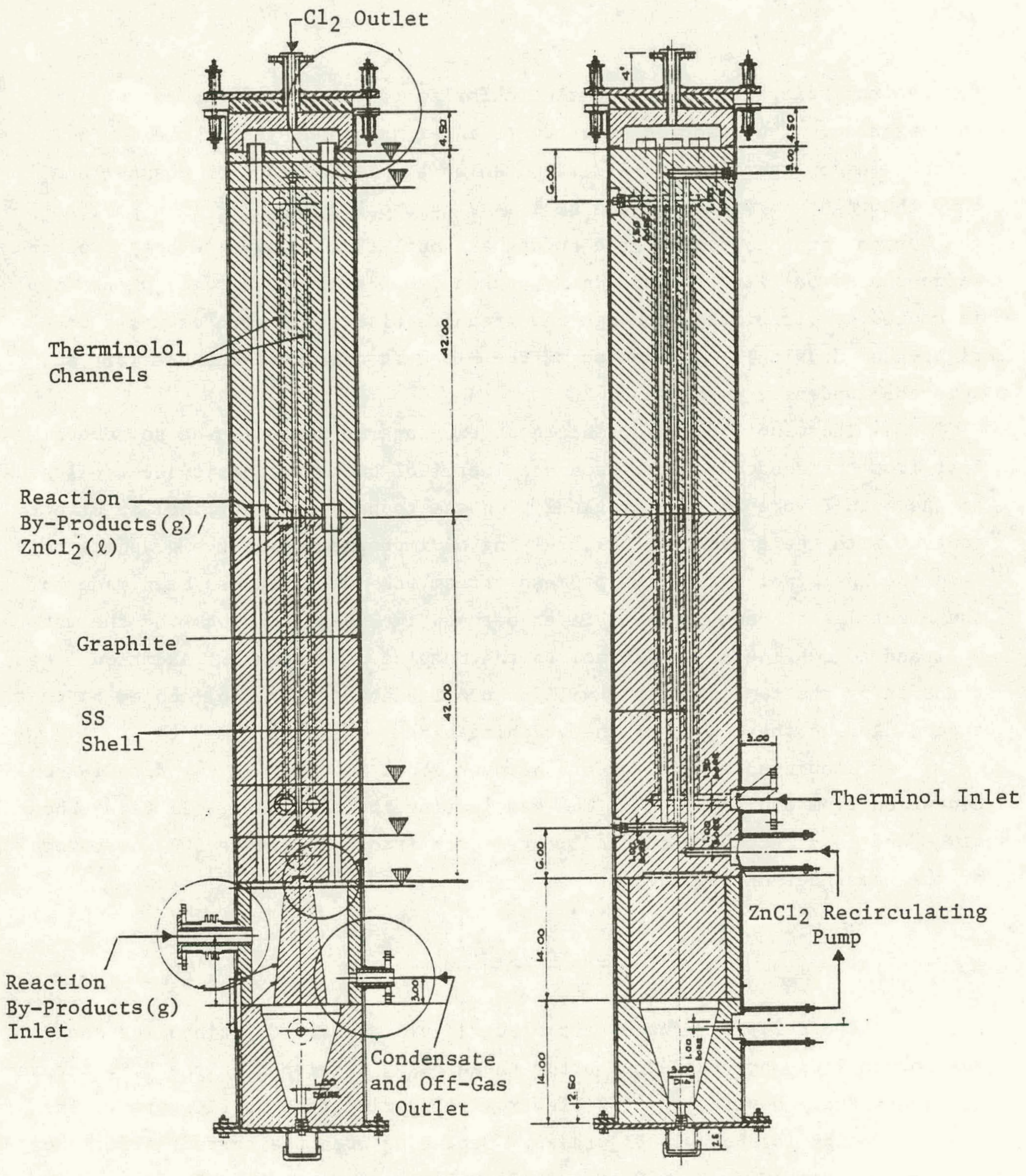

FIGURE 24. $\mathrm{ZINC} / \mathrm{ZnCl} 2$ CONDENSER 
for recirculating the condensed zinc chloride to act as a fluid for wet-wall condensation. The reaction by-products enter the condenser at the lower left of the view on the left and are directed up the left-hand open channel and down the right by virtue of the seal made by the liquid $\mathrm{ZnCl}_{2}$ in a pool at the bottom, at the level of the condensate outlet and above the bottom of the wedge-shaped barrier. Liquid $\mathrm{ZnCl}_{2}$, taken from below the surface of the pool is cooled by circulation through the graphite block (see open channels on right-hand drawing). At the top of the block it overflows the barriers and wets the condenser surfaces.

Therminol 88, an organic heat exchange medium, is used to remove heat from the condenser to a separate Therminol heat-exchange system. Although as shown in Figure 24, the original plan was to have the Therminol in direct contact with the graphite block, relying on impregnation of the graphite to keep the Therminol out of the process stream, the decision has been made to use a metal shot heat-transfer layer between the graphite block and the metal wall and to confine the Therminol to the outside of the wall. Additional heat transfer by the same principle will be provided by a Therminol-cooled bayonet extending down the center of the graphite block.

Zinc condensation occurs between about 800 and $690 \mathrm{C}$ and $\mathrm{ZnCl}_{2}$ condensation from 690 to $565 \mathrm{C}^{*}$. The gas leaving the condenser w1ll be at about $510 \mathrm{C}$ and is directed to the $\mathrm{ZnCl}_{2}$ strippers (shown in Figure 20) for removal of the remainder of the $\mathrm{ZnCl}_{2}$.

\section{Electrolytic Cell}

The cells for fused salt electrolysis recovery of zinc from the by-product $\mathrm{ZnCl}_{2}$ are patterned after those being developed at the U.S. Bureau of Mines, Reno, Nevada, (17) for electrowinning zinc from sulfide ores. The present design is shown in Figure 25. Depending upon the current efficiency attainable, six 5000- to 6000-amp cells will be required for the $50 \mathrm{MT} /$ year

* The difference in these values from those of Table 13 results from use of different data in their calculation. The difference is not serious enough to force a choice. 


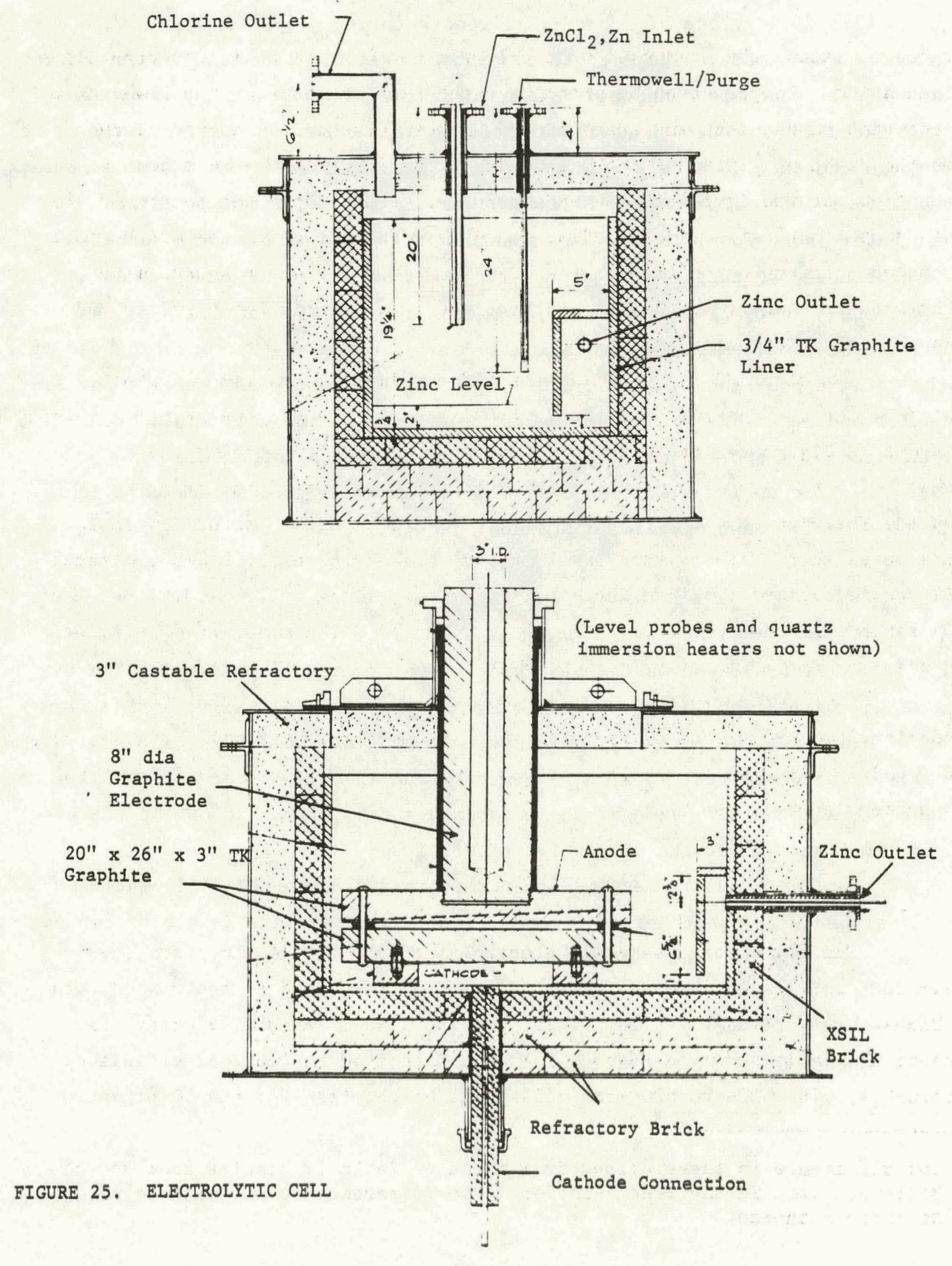


Si facility. They are of "cold"-wall construction, graphite lined, with graphite electrodes. The cathode contacts the liquid zinc pool at the bottom of the cell which is connected to the current supply via a plug of frozen zinc extending through the cell wall (Shown at the bottom, but probably to be through the side). A cell voltage of 4 to 5 volts is anticipated at a current density of 10 to 12 amps/in.2. Excess heat is removed thruugh a hcat exchanger (not shown) in the hollow anode. By means of electric contact level probes (of tungsten or graphite), not shown in the figure, upper and lower $\mathrm{ZnCl}_{2}$ level limits are set to control the addition of $\mathrm{ZnCl}_{2}$ to the cell. The zinc overflows automatically on balancing the hydrostatic head of the $\mathrm{ZnCl}_{2}$ approximately at the $\mathrm{ZnCl}_{2}$ lower level limit. Blockage of the zinc outlet and resulting excess accumulation of zinc in the cell would be indicated by a shortcd cell as the zinc level reaches the anode.

The entire electrode assembly is removable through the cell roof to provide for ease of cell maintaince.

\section{Plant Layout}

Figure 26 shows the plan view of the facility, as designed to fit into an available bulldily area at BCL. As the zinc and zinc chloride flow is by gravity*, the $\mathrm{Zn} / \mathrm{ZnCl}_{2}$ condenser, electrolysis feed tank, electrolytic cells, zinc storage tank, zinc level tank, and zinc vaporizer are on different levels. Accordingly, some of the associated units are not shown in the plan view of Figure 26 at the electrolytic cell 1 evel.

The layout is designed to permit ready access for $\mathrm{SiCl}_{4}$ and $\mathrm{NaOH}$ delivery and for hypochlorite removal, and to minimize the length of connecting lines carrying zinc and zinc chloride.

* Except for pumped recycle of liquid $\mathrm{ZnCl}_{2}$ in the wet-wall $\mathrm{Zn} / \mathrm{ZnCl}_{2}$ condenser. 


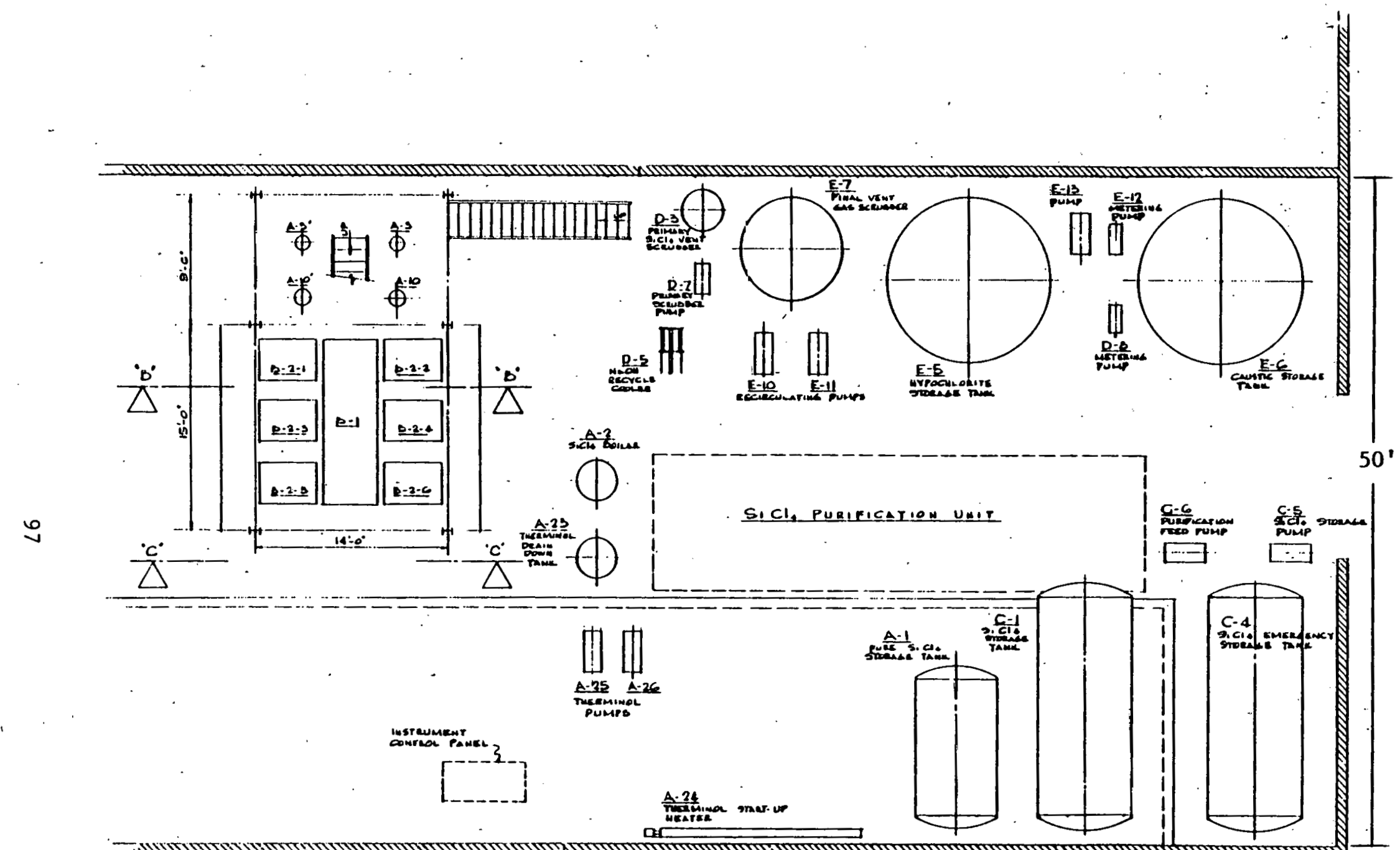

- =

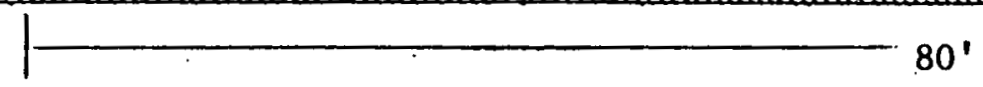

FIGURE 26. PLAN VIEW. 
Cost of Experimental Facility

It should be re-emphasized that many of the detalls and most of the specifications in the design package have been omitted in the above discussion which has been presented primarily for orlentation. $\therefore$ However, on the basis of a detalled summation of the vendor-estimated costs for equipment costs of the instrument package, and construction costs based on standard. construction cost-estimating techniques, RKAII arrived at an initial cost. estimate of $\$ 1,536,000$, of which $\$ 266,500$ for the $\mathrm{SICl}_{4}$ purification system was estimated independently by Pace. The uverall cost eatimate arrived at by RRAII includes all procurement, installation, management, and tax costs for constructing this faclifty in an existing building by a company building the facillty for its own use. A contingency item of $\$ 191,139$ was included.

Because of differences in overhead, fee structure, and labor rates, the cost of bullding the facility at BCL would be higher; however, removal of the contingency item, credit of certain f́conomies agreed upon by BCL and RKAII, and adjustment for the differences mentioned above led to a flgure of $\$ 1.5$ million*, which was presented to JPL for budgetary purposes. This estimate is based on purchasing equipment from outside, vendors, subcontracting a signiflcant portion of the construction and installation to an outslde contractor, $B C L$ 's Involvement in construction and installation . of nonconventional equipment, and overall.management of the program by BCL perisoninel.

* This facility construction cost, revised later to $~ \$ 1.6$ million, docs not include the cost of a concurrent design finalization and experimental support program. 


\title{
E. ECONOMIC ANALYSIS OF SILICON PRODUCTION
} AT THE $1000 \mathrm{MT} /$ YEAR LEVEL

\begin{abstract}
One of the objectives of the design of the $50 \mathrm{MT} /$ year EPF was .. to provide a firmer basis on which to estimate production costs at the $1000 \mathrm{MT} /$ year level, which should be more reliable than those given in the Second Quarterly Report. For that purpose, the costs of individual items. of capital equipment in the $50 \mathrm{MT} /$ year design were scaled to an appropriate
\end{abstract} larger size by the relation

$$
\text { relative cost }=\text { (relative capacity) } 0.6 \text {, }
$$

and then multiplied by the number of units required to meet the $1000 \mathrm{MT} /$ year capacity.

At the same time, the manpower, materials, and utilities costs were revised on the basis of the $50 \mathrm{MT} /$ year design and experience gained since the earlier cost estimates were made.

Table 24 lists the ltems of equipment for the $50 \mathrm{MT} /$ year EPF on which the estimates for the $1000 \mathrm{MT} /$ year plant are based.

Three cases are defined as follows:

Case I

(1) Six parallel feed preparation and deposition systems (17-inch-diameter fluidized-bed reactors)

(2) Twelve 60,000-amp electrolytic cells for zinc recycle

(3) One common waste disposal system

(4) One common chlorine supply system (for chlorination of wall deposit)

Case II

(1) Two parallel feed preparation and deposition systems (29-1nch-diameter fluidized-bed reactors)

(2) Twelve 60,000-amp electrolytic cells for zinc recycle, with an option of two 360,000 -amp cells 
TABLE 24. LIST OF EQUIPMENT FOR THE 50 MT/YEAR EXPERIMENTAL FACILITY UPON WHICH THE COST ESTIMATES FOR A 1000 MT/YEAR PLANT ARE BASED

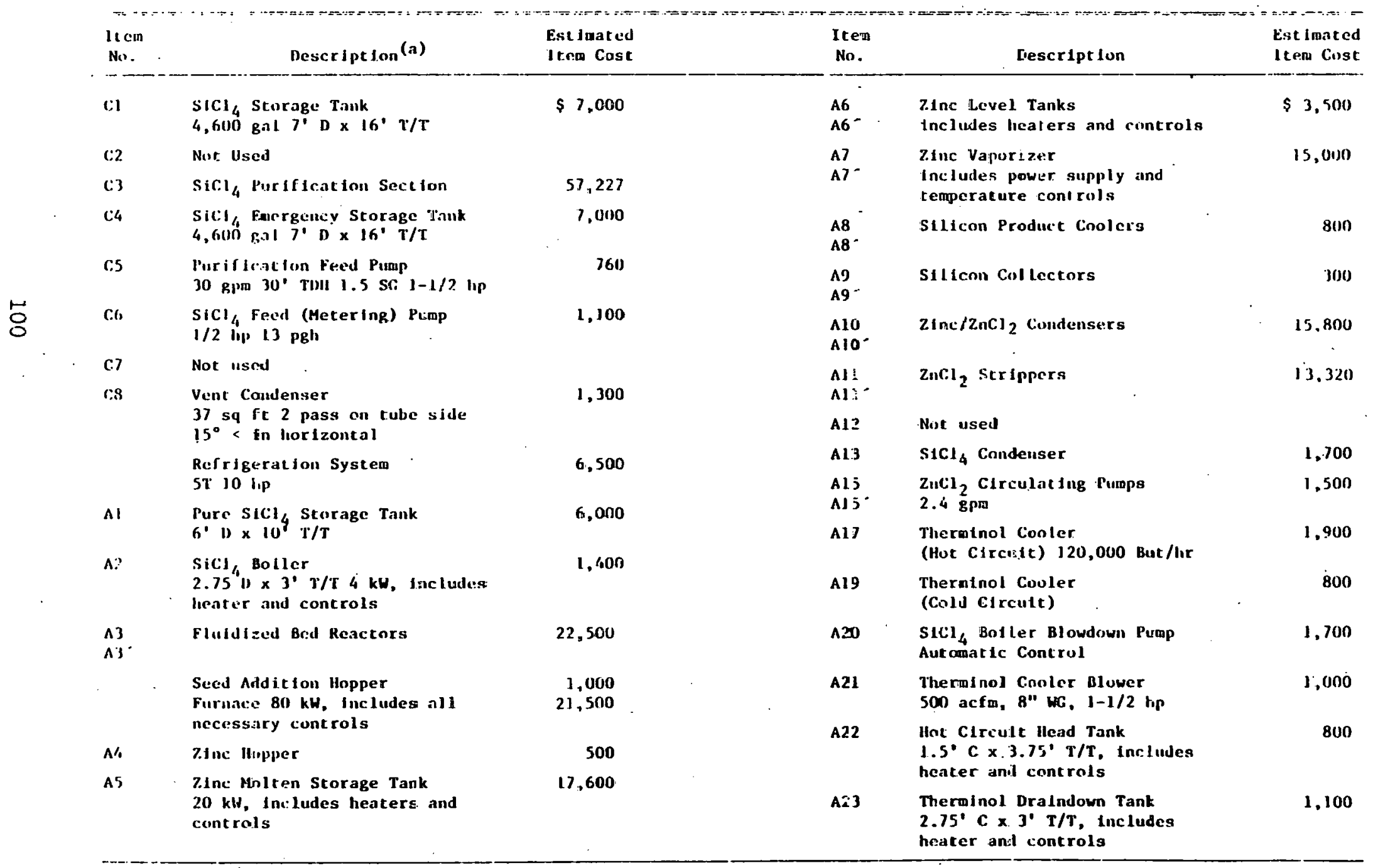

(A) Itcms Indicated as "not used" were either dropped (rom the or 1 ginal 50 MTiyear facillty design or will not be used In a lono MT/yrar plant. 
TABLE 24. (Continued)

\begin{tabular}{|c|c|c|c|c|c|}
\hline $\begin{array}{l}\text { Itern } \\
\text { No. }\end{array}$ & Descript ion & $\begin{array}{l}\text { Estimated } \\
\text { Item Cost }\end{array}$ & $\begin{array}{l}\text { Item } \\
\text { No. }\end{array}$ & Eestription & $\begin{array}{l}\text { Eat tuated } \\
\text { ltem cost }\end{array}$ \\
\hline A24 & $\begin{array}{l}\text { Start-Up lieater } \\
29 \mathrm{~kW}\end{array}$ & $\$ 2,000$ & D8 & $\begin{array}{l}\text { Makpup HaOH Hetering Pump } \\
1 / 2 \text { lip }\end{array}$ & $\$ 1,700$ \\
\hline A25 & llot Gircuit Pump & 2,900 & El & Not Used & \\
\hline A26 & Cold Circult Pump & 1,400 & E2 & Not used & \\
\hline A27 & $\begin{array}{l}\text { Sil: } 1_{4} \text { Feed Pump } \\
1 \text { gph e } 488^{\circ} \text { rofl }\end{array}$ & 300 & $\begin{array}{l}53 \\
\text { E.4 }\end{array}$ & $\begin{array}{l}\text { Not used } \\
\text { Not used }\end{array}$ & \\
\hline ถุı & $\begin{array}{l}\text { Electrolysis Feed Tank } \\
20 \mathrm{kH} \text {, Includes heaters and }\end{array}$ & 17,600 & E5 & Not used & \\
\hline $\begin{array}{l}B 2 \\
A-F\end{array}$ & $\begin{array}{l}\text { controls } \\
\text { Electrolysis Cella } \\
\text { Power Supply } 160 \mathrm{kH}\end{array}$ & $\begin{array}{r}9,700 \\
15,300\end{array}$ & E6 & $\begin{array}{l}\text { Caust ic. Sturage Tank } \\
12,000 \text { gal capactty } \\
12^{\circ} \mathrm{D} \times 14^{\circ} \cdot 6^{\prime \prime} \mathrm{T} / \mathrm{T}\end{array}$ & 8.500 \\
\hline & Bus & 7,600 & E7 & $\begin{array}{l}\text { Final Vent Gas Scrubber } \\
7^{\prime} 6^{\prime \prime} D \times 17^{\prime} 4^{\prime \prime} T / T\end{array}$ & 14.000 \\
\hline $\begin{array}{l}\text { B3 } \\
134\end{array}$ & $\begin{array}{l}\mathrm{ZnCl}_{2} \text { Strippers } \\
\text { Not ust:d }\end{array}$ & 4,480 & & $\begin{array}{l}\text { four polyproplene trays } \\
\text { Teflon mist elimfuator }\end{array}$ & \\
\hline $\begin{array}{ll}F 3 \\
F 4\end{array}$ & $\begin{array}{l}\text { Not used } \\
\text { Ciblorlne Supply Tank }\end{array}$ & 500 & $\begin{array}{l}\text { f.8- } \\
182\end{array}$ & $\begin{array}{l}\text { Eductor } \\
\text { Penlierthy Series } 60 \\
\text { Size Lt.-2" }\end{array}$ & 300 \\
\hline $\begin{array}{l}11 \\
112\end{array}$ & $\begin{array}{l}\text { Not used } \\
\text { Not used }\end{array}$ & & E9 & $\begin{array}{l}\text { ID Fan } \\
10,000 \text { acfm } \odot 15^{\prime \prime} \text { WG so hp }\end{array}$ & 6,800 \\
\hline 103 & $\begin{array}{l}\text { Primary SiCl } 4 \text { Vent Scrubber } \\
3^{\prime} \mathrm{D} \times 44^{\prime \prime} \mathrm{T} / \mathrm{T} \text {, flat bot }\end{array}$ & 1,000 & E10 & $\begin{array}{l}\text { Primary Loop Recirculation. Pump. } \\
100 \mathrm{gpm} \text { e } 100^{\circ} \mathrm{TDH} 8 \mathrm{hp}\end{array}$ & 1,890 \\
\hline $\mathrm{D}_{1}$ & Hot usr:d & . & E11 & $\begin{array}{l}\text { Secondary Loop Recirculation } \\
\text { Pump: } 100 \text { gpo } 30^{\circ} \text { TDII } 2 \text { hp, }\end{array}$ & 1,830 \\
\hline DS & $\begin{array}{l}\text { NaOll Recycle Cooler } \\
\text { Plate and Frame Ekchanger }\end{array}$ & 5,100 & E12 & $\begin{array}{l}\text { Makeup NiOH Metering Pump } \\
54 \mathrm{gph} 1 / 2 \mathrm{hp}\end{array}$ & 1,700 \\
\hline $\begin{array}{l}\text { Dij- } \\
182\end{array}$ & $\begin{array}{l}\text { Eluctor } \\
\text { I'entertlyy Series } 60 \\
\text { Size } 1.1,-1-1 / 2 \text { " }\end{array}$ & $1 / 0$ & E13 & $\begin{array}{l}\text { F111/Drain Pump } \\
100 \text { gpm e } 300^{\circ} \text { TDH } 2 \text { lip }\end{array}$ & 1,830 \\
\hline D7 & $\begin{array}{l}\text { Primary Scrubber Recirculation } \\
\text { Punu; ; } 20 \text { gpme } 125 \text { TDll } 2.5 \mathrm{lp}\end{array}$ & 1,160 & E14 & Not used & \\
\hline
\end{tabular}


(3) Oisc cummon waste disposal system

(4) One common chlorine supply system

\section{Case III}

(1) One feed preparation and deposition

system (41-inch-diameter fluidized-bed reactor)

(2) One 720,000-amp electrolytic cell for zinc recycle, with an option of six 120,000-amp cells

(3) Onc common waste disposal system

(4) Une common chlorine supply system.

Except for the use of fewer (12 versus 30) larger electrolytic cells, Case I is essentially that adopted for the original cost estimate. Case II reflects the savings that accrue from going to fewer (two versus six) and larger (29-inch versus 17-inch) fluidized-bed reactors and associated equipment.

Case III represents the minimum-cost option, which would use a single 41-inch-diameter fluidized bed and one 720,000-amp electrolytic cell. Fluidized beds of that size are operated in the petrochemical industry and preliminary calculations have shown that extraction of the exothermic heat of reaction does not constitute a size limitation, even at 60-inch diameter. Bipolar electrolytic cells of up to $10^{6}$ equivalent amp are under construction for the electrolytic recovery of aluminum. Thus, although Case III is a large extrapolation from the technology anticipated for use at the $50 \mathrm{MT} /$ year level, it appears to be ultimately accessible.

Since some optimum multiplicity of units will be required to maintain a steady operation, more than a single unit should be operated at a given site, even at the $1000 \mathrm{MT} /$ year/unit level. Case III would envision operating three $1000 \mathrm{MT} /$ year units at one site to fulfill the $3000 \mathrm{MT} /$ year goal of the LSA Project.

It should be noted that although the purchase of $\mathrm{SiCl}_{4}$ is planned at the $50 \mathrm{MT} /$ year level, the $\mathrm{SiCl}_{4}$ will be generated at the $1000 \mathrm{MT} /$ year level by reaction of metallurgical-grade silicon with chlorine from the 
electrolytic cells. However, the capital, labor, materials, and manpower requirements of that operation have not been calculated in detail. Instead, all of these costs are included in a materials cost for $\mathrm{SiCl}_{4}$, calculated at lowest market price plus 20 percent credit for on-site manufacture instead 'of purchase. The resulting $\mathrm{SiCl}_{4}$ material cost of $\$ 1.69$ per $\mathrm{kg}$ of silicon product is assumed to be constant for the three cases. This is equivalent to the assumption that the size of the $\mathrm{SiCl}_{4}$ preparation unit(s) does not change from Case I to Case III, a conservative position.

Since the raw material is factored in as $\mathrm{SiCl}_{4}$, rather than as metallurgical-grade silicon and chlorine, a $\$ 0.37 / \mathrm{kg} \mathrm{Si} \mathrm{credit} \mathrm{is} \mathrm{given} \mathrm{for}$ the by-product chlorine.

Table 25 gives the equipment costs, scaled as indicated above, for Cases I, II, and III for each of the six sections of the plant.

Table 26 gives the manpower breakdown and costs for the three cases. The materials requirements given in Table 27 are essentially the same for the three $1000 \mathrm{MT} /$ year cases as those for the $50 \mathrm{MT} /$ year facility except for the nitrogen blanket gas whose requirement was scaled up from the $50 \mathrm{MT} /$ year level by (relative use) $=$ (relative size) 0.5 . For simplification, the utility costs given in Table 28 are assumed to be common to the three cases, a conservative position. Process energy requirements for Items 1 through 7 and part of 8 are assumed to be constant with scale; however, as heat losses per unit volume decrease with increasing size, the overall kw per $\mathrm{kg}$. of silicon also decreases. The heat losses from process untts and from line tracing (Items 9 and 10) were scaled on the basis of area $\alpha$ volume $2 / 3$, i.e.,

$$
(\text { relative loss })=(\text { relative size })^{2 / 3} \text {. }
$$

Although it will not be necessary in the $1000 \mathrm{MT} /$ year facility to convert the chiorine from the electrolytic cells to $\mathrm{NaOCl}$, a vent and area gas scrubber of the same size as used in the $50 \mathrm{MT} /$ year facility for the scrubbing and waste disposal functions w11l be required for the $1000 \mathrm{MT} /$ year facllity. Hence, the energy requirement for the $50 \mathrm{hp}$ blower was distributed over the $144 \mathrm{~kg} / \mathrm{hour}$ silicon output of the $1000 \mathrm{MT} /$ year facllity. 
TABLE 25. EQUIPMENT COSTS (1975 DOLLARS) BY GROUPS FOR $50 \mathrm{MT} /$ YEAR EXPERIMENTAL FACILITY AND $1000 \mathrm{MT} /$ YEAR PLANT -- CASES I, II, AND III*

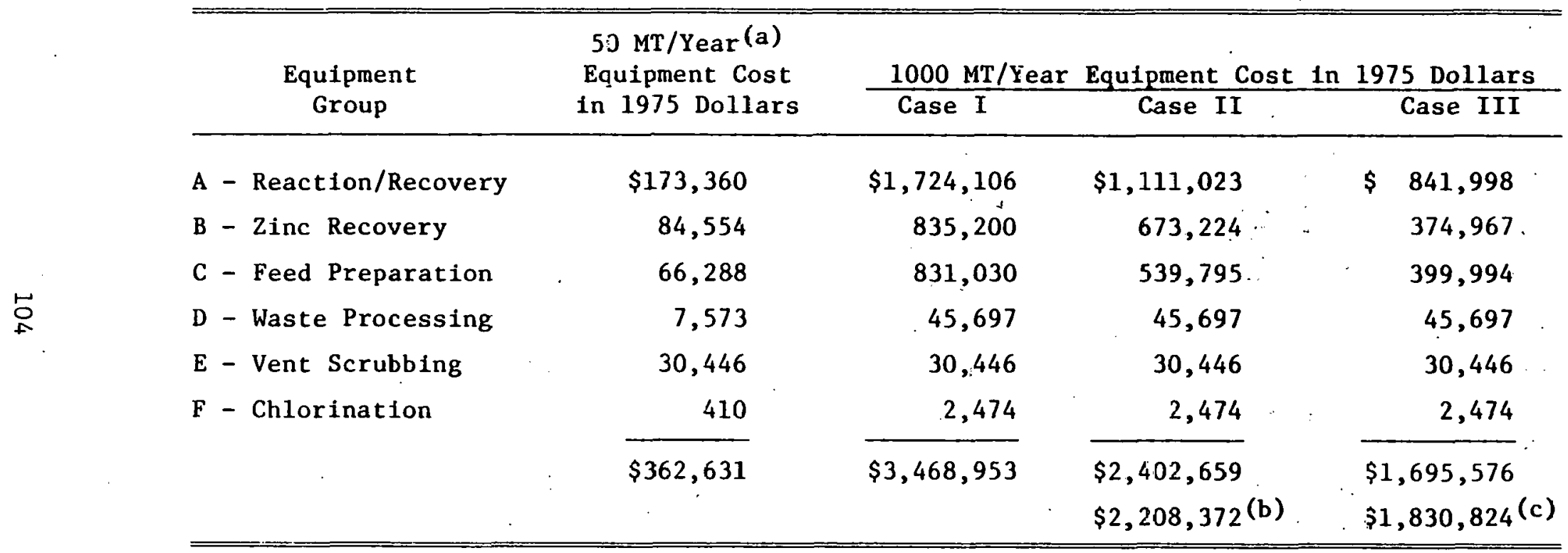

(a) Includes items used only in $1000 \mathrm{MT} /$ year facility.

(b) Based on two 360,000-amp cells instead of twelve 60,000-amp cells.

(c) Based on six 120,000-amp cells instead of one 720,000-amp cel1.

${ }^{*}$ CE Equipment Index: $1975-191.6 ; 1978$ (February) - 233.8; factor - 0.8195. 
TABLE 26. MANPOWER BREAKDOWN AND $\operatorname{COSTS}(a, b)$

\begin{tabular}{|c|c|c|c|c|c|c|}
\hline \multirow{3}{*}{$:$ Operation } & \multicolumn{6}{|c|}{ Manhours per Day } \\
\hline & \multicolumn{2}{|c|}{ Case I } & \multicolumn{2}{|c|}{ Case II } & \multicolumn{2}{|c|}{ Case III } \\
\hline & Skilled & $\begin{array}{c}\text { Semi- } \\
\text { Skilled }\end{array}$ & Skilled & $\begin{array}{c}\text { Semi- } \\
\text { Skilled }\end{array}$ & Sk1lled & $\begin{array}{c}\text { Semi- } \\
\text { Skilied }\end{array}$ \\
\hline Feed Preparation & 12 & 11 & 4 & 12 & 4 & 12 \\
\hline Vaporization & 12 & 11 & 4 & 12 & 4 & 12 \\
\hline Deposition & 12 & 19 & 4 & $12^{\circ}$ & 4 & 12 \\
\hline Condensation & 12 & 11 & 4 & 12 & 4 & 12 \\
\hline Electrolysis & 18 & 18 & 4 & 12 & 4 & 12 \\
\hline Waste Treatment & 8 & 8 & 4 & 12 & 4 & 12 \\
\hline Product Handling. & & 36 & & 16 & & 16 \\
\hline Raw Material Handling & & 36 & & 16 & & 16 \\
\hline & 74 & 150 & 24 & 104 & 24 & 104 \\
\hline Dollars per day & $\$ \quad 1,1$ & 78.4 & $\$$ & 636.8 & $\$$ & 636.8 \\
\hline Dollars per year & $\$ 420,6$ & & $\$ 227$, & 338 & $\$ 227$, & 338 \\
\hline
\end{tabular}

(a) Labor hours/process based on Peters and Timmerhaus (5) number of operator hours/major process step.

(b) Labor rate based on Peters and Timmerhaus (5) adjusted to 1975 dollars: Skilled - $\$ 6.60 /$ hour

Semi-Skilled - $\$ 4.60 /$ hour 
TABLE 27. MATERIALS COST (1975 DOLLARS)

\begin{tabular}{cccc}
\hline Mater1al & $\begin{array}{c}\text { Requirement per } \\
\mathrm{kg} \mathrm{Si}\end{array}$ & $\begin{array}{c}\text { Unit Cost, } \\
\text { dollars }\end{array}$ & $\begin{array}{c}\text { Cost/kg Si, } \\
\text { dollars }\end{array}$ \\
\hline $\begin{array}{c}\text { SiCl } 4 \\
\text { Zinc }\end{array}$ & $\begin{array}{c}15.68 \mathrm{lb} \\
\text { Caust1c }\end{array}$ & $0.135 \times 0.8(\mathrm{a})$ & .1 .69 \\
$\begin{array}{c}0.54 \mathrm{lb} \\
\text { aq. NaOH) }\end{array}$ & $2.4 \mathrm{lb}$ & 0.39 & 0.21 \\
$\begin{array}{c}\text { Argon } \\
\text { N1trogen } \\
\text { Chlorine }\end{array}$ & $3.1 \mathrm{scf}$ & 0.063 & 0.15 \\
& $7.6 \mathrm{scf}$ & 0.016 & 0.05 \\
\hline \hline
\end{tabular}

(a) Credit for on-site manufacture. 
TABLE 28. UTILITIES COST (1975 DOLLARS)

\begin{tabular}{|c|c|c|c|c|c|}
\hline & Item $(a)$ & & Requirement/kg & Si & \\
\hline & Zinc Electrolysis & 21.56 & kwh (b) & & \\
\hline 2. & Zinc Vaporization & 4.24 & kwh & & \\
\hline 3. & Zinc Melting & 0.02 & kwh & & \\
\hline & $\mathrm{SiCl}_{4}$ Vaporization & 0.00 & $k w h(c)$ & & \\
\hline & $\mathrm{SiCl}_{4}$ Preheating & 1.45 & kwh & & \\
\hline & $\begin{array}{l}\text { Fluidized-Bed Reduction } \\
\text { Reaction }\end{array}$ & 0.00 & $k w h(d)$ & & \\
\hline & $\mathrm{SiCl}_{4}$ Purification & 1.80 & $k w h(e)$ & & \\
\hline & Pumps, Blowers & 4.0 & kwh & & \\
\hline & $\begin{array}{l}\text { Heat Losses from Process } \\
\text { Units }\end{array}$ & 1.94 & kwh & & \\
\hline 10. & Liṇe Tracing & 1.24 & kwh & & 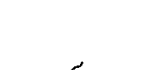 \\
\hline 11. & Instrumentation & 0.21 & kwh & & \\
\hline & Subtotal Electrical & 36.46 & $\overline{\text { kwh }} @ \$ 0.03$ & $=$ & $\$ 1.094$ \\
\hline 12. & Cooling Water & 180.0 & gal @ $\$ 0.04 / 1000$ & $=$ & $\$ 0.007$ \\
\hline 13. & Process Water & 2.6 & gal @ $\$ 1.00 / 1000$ & $=$ & $\$ 0.003$ \\
\hline & TOTAL UTILITIES & & & & $\$ 1.104$ \\
\hline
\end{tabular}

(a) Primarily endothermic process heat in Items 1 through 8 , except for Item 1 which includes resistive heat loss; heat losses from process units, insulated to OSHA standards, are included in Item 9.

(b) At $2 \mathrm{kwh} / 1 \mathrm{~b} \mathrm{zn}$.

(c) $0.63 \mathrm{kwh}$ supplied by heat exchange with $\mathrm{Zn} / \mathrm{ZnCl}_{2}$ condenser.

(d) Exothermic reaction.

(e) Additional $3.8 \mathrm{kwh}$ supplied by heat exchange with $\mathrm{Zn} / \mathrm{ZnCl}_{2}$ condenser. 
It was assumed that the instrumentation power costs for one of the six sections of the $1000 \mathrm{MT} /$ year facility in Case I would equal that for the $50 \mathrm{MT} /$ year facility and that this cost would remain the same for Cases II and III, again a conservative position.

Table 29 gives the fixed capital investment costs for Cases I, II, and III based on Table 25 .

Table 30, in the Lamar University format ${ }^{(18)}$, gives the total product cost on the basis of Tables 26, 27, 28, and 29. It can be seen from the data of Table 30 that for all of the cases analyzed, the cost of silicon produced by the fluldized-bed zinc reduction of ${\mathrm{S} 1 C l_{4}}_{4}$ falls near the $\$ 10 / \mathrm{kg}$ sillcon LSA goal, with Cases II and III beating the goal by $\$ 1.29$ and $\$ 2.65$, respectively. Case II is a reasonable expectation for 1985 and Case III is a logical longrange goal.

The options on electrolytic cell size described previously for Cases II and III as Indicated in Table 30 reflect a decrease of $\$ 0.38 / \mathrm{kg}$ of silicon and an increase of $\$ 0.26 / \mathrm{kg}$ of silicon in product cost, respectively. The options are presented because the trade-offs with cell size are not yet clearly understood and, consequently, data of this type are required to give insight into the effect of cell size on product cost.

\section{Energy Payback}

The process energy requirements (exclusive of pumping of ut1lity water and other minor 1tems) from Table 28 total $36.46 . \mathrm{kwh} / \mathrm{kg}$ s1l1con. To this must be added the energy requirement of the metallurgical-grade silicon used, that of the make-up chlorine, make-up zinc, and that of the NaOH used to neutralize the chloride and chlorine wastes. Table 31 gives the energy requirements per $\mathrm{kg}$ of silicon. At $12,000 \mathrm{MT}$ silicon per peak megawatt $(60,000 \mathrm{MT} /$ average $\mathrm{mw}, 0.0167 \mathrm{kw} / \mathrm{kg})$, the power generation cred1t is $12.10 \mathrm{kwh} /$ month, whence the payback time is 5.9 months. The power generation rate is the equivalent of about 50 percent silicon material loss in the fabrication of $0.0254-\mathrm{cm}$-thick cells generating $0.1 \mathrm{kw} / \mathrm{m}^{2}$ over 1825 hours/year. 
TABLE 29. FIXED CAPITAL INVESTMENT

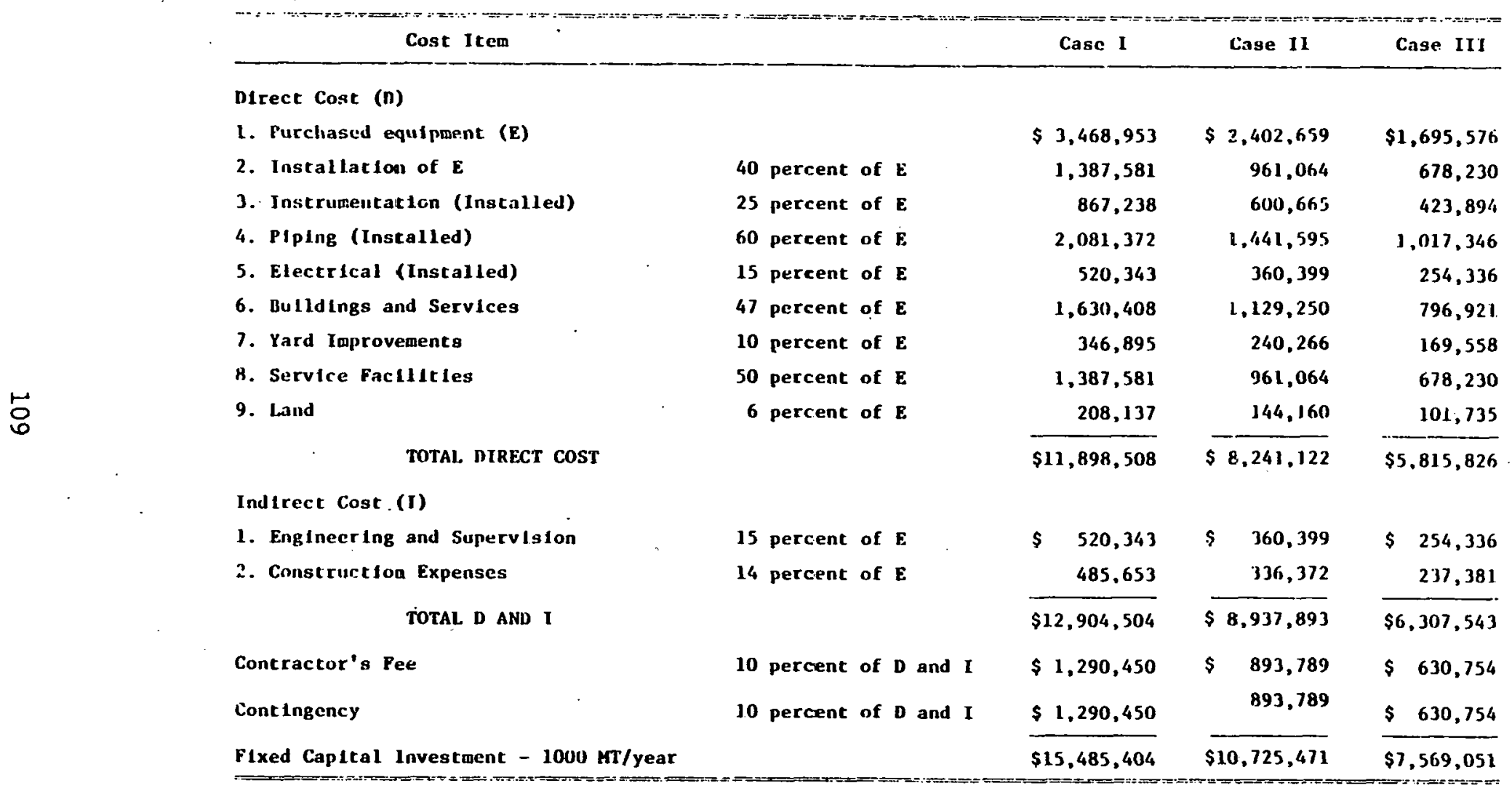




\begin{tabular}{|c|c|c|c|c|}
\hline & Cost Item & Case I & Case II & Case III \\
\hline \multirow[t]{9}{*}{1.} & $\begin{array}{l}\text { Direct Manufacturing Cost } \\
\text { (Direct Charges) }\end{array}$ & & & \\
\hline & 1. Raw Materials - from design & $\$ 2.26(a)$ & $\$ 2.26(a)$ & $\$ 2.26(a)$ \\
\hline & $\begin{array}{l}\text { 2. Direct Operating Labor - } \\
\text { from design }\end{array}$ & 0.42 & 0.23 & 0.23 \\
\hline & 3. Utilities - from design & 1.10 & 1.10 & 1.10 \\
\hline & $\begin{array}{l}\text { 4. Supervision and Clerical, } \\
15 \text { percent of } 1.2 \\
\text { 5. Maintenance and Repairs, }\end{array}$ & 0.06 & 0.03 & 0.03 \\
\hline & $\begin{array}{l}10 \text { percent of fixed capital } \\
\text { (50 percent labor, 50.per- } \\
\text { cent materials) }\end{array}$ & 1.55 & 1.07 & 0.76 \\
\hline & $\begin{array}{l}\text { 6. Operation Supplies, } 20 \text { per- } \\
\text { cent of } 1.5\end{array}$ & 0.31 & 0.22 & 0.15 \\
\hline & $\begin{array}{l}\text { 7. Laboratory. Charge, } 15 \text { per- } \\
\text { cent of } 1.2\end{array}$ & 0.06 & 0.03 & 0.03 \\
\hline & $\begin{array}{l}\text { 8. Patents and Royalties, } \\
3 \text { percent of product } \\
\text { cost }\end{array}$ & 0.34 & 0.26 & 0.22 \\
\hline \multirow[t]{5}{*}{2.} & $\begin{array}{l}\text { Indirect Manufacturing Cost } \\
\text { (Fixed Charges) }\end{array}$ & $\therefore$ & . & \\
\hline & $\begin{array}{l}\text { 1. Depreciation, } 10 \text { percent of } \\
\text { fixed capital }\end{array}$ & $\$ 1.55$ & $\$ 1.07$ & $\$ 0.76$ \\
\hline & $\begin{array}{l}\text { 2. Local Taxes, } 2 \text { percent of } \\
\text { fixed capital }\end{array}$ & 0.31 & 0.22 & 0.15 \\
\hline & $\begin{array}{l}\text { 3. Insurance, } 1 \text { percent of } \\
\text { fixed capital }\end{array}$ & 0.16 & 0.11 & 0.08 \\
\hline & $\begin{array}{l}\text { 4. Interest, } 8 \text { percent of } \\
\text { fixed capital }\end{array}$ & 1.24 & 0.87 & 0.62 \\
\hline 3. & $\begin{array}{l}\text { Plant Overhead, } 60 \text { Percent of } \\
\text { Labor in } 1.2+1.4+1.5\end{array}$ & $\$ 0.75$ & $\$ 0.48$ & $\$ 0.38$ \\
\hline 4. & By-Product Credit - From Design & $-\$ 0.37(b)$ & $-\$ 0.37^{(b)}$ & $-\$ 0.37(b)$ \\
\hline 4A. & $\begin{array}{l}\text { Total Manufacturing Cost, } \\
1+2+3+4\end{array}$ & $\$ 9.74$ & $\$ 7.58$ & $\$ 6.40$ \\
\hline
\end{tabular}


TABLE 30. (Continued)

\begin{tabular}{lccc}
\hline \multicolumn{1}{c}{ Cost Item } & Case I & Case II & Case III \\
\hline 5. General Expenses & & & \\
1. Administration, 6 percent & $\$ 0.59$ & $\$ 0.45$ & $\$ 0.38$ \\
$\begin{array}{l}\text { of manufacturing cost } \\
\text { 2. Distribution and Sales, } \\
\quad \begin{array}{l}\text { percent of manufacturing } \\
\text { cost }\end{array}\end{array}$ & 0.59 & 0.45 & 0.38 \\
$\begin{array}{l}\text { 3. Research and Development, } \\
\quad \begin{array}{l}\text { percent of manufacturing } \\
\text { cost }\end{array}\end{array}$ & 0.29 & 0.23 & 0.19 \\
6. Total Cost of Product, 4A +5 & $\$ 11.21$ & $\$ 8.71$ & $\$ 7.35$ \\
\hline
\end{tabular}

(a) Includes all cost (operating and capital investment) for the manufacture of $\mathrm{SiCl}_{4}$ used.

(b) Credit for by-product chlorine; see text.

(c) Based on the use of two 360,000-amp cells instead of twelve 60,000amp cells.

(d) Based on the use of six 120,000-amp cells instead of one 720,000-amp cell. 
TABLE 31. ENERGY REQUIREMENTS, $\mathrm{kwh} / \mathrm{kg} \mathrm{S1}$

\begin{tabular}{|c|c|c|c|}
\hline & Item & Basis & $\begin{array}{c}\text { Energy } \\
\text { Requirement, } \\
\text { kwh/kg S1 }\end{array}$ \\
\hline \multicolumn{2}{|c|}{ Process } & Table 28 & 36.46 \\
\hline \multicolumn{2}{|c|}{ Make-up $\mathrm{Cl}_{2}$} & $2.04 \mathrm{lb} / \mathrm{kg} \mathrm{Si} @ 1.54 \mathrm{kwh} / 1 \mathrm{~b}$ (a) & $---(b)$ \\
\hline \multicolumn{2}{|c|}{$\mathrm{NaOH}$} & $\begin{array}{l}2.4 \mathrm{lb} / \mathrm{kg} \mathrm{Si} \mathrm{@} 1.37 \mathrm{kwh} / \mathrm{lb}{ }^{(\mathrm{a})} ; \\
97 \text { percent utilization }\end{array}$ & 3.29 \\
\hline \multicolumn{2}{|c|}{ Make-up z1nc } & $0.54 \mathrm{lb} / \mathrm{kg} \mathrm{S} 1$ @ $2 \mathrm{kwh} / 1 \mathrm{~b}(\mathrm{c})$ & 1.08 \\
\hline \multicolumn{2}{|c|}{ Metallurgical-grade Si } & $\begin{array}{l}1.27 \mathrm{~kg} / \mathrm{kg} \mathrm{Si} @ 23.97 \mathrm{kwh} / \mathrm{kg}^{(\mathrm{d})} \text {; } \\
95 \text { percent utilization }\end{array}$ & .30 .44 \\
\hline \multicolumn{2}{|r|}{ : } & & 71.27 \\
\hline (a) & Reference (22). & & \\
\hline (b) & Co-product of $\mathrm{NaOH}$ & production. & \\
\hline (c) & $\begin{array}{l}\text { Conservative estim } \\
\text { projected by U. S. }\end{array}$ & $\begin{array}{l}\text { te of } 2 \mathrm{kwh} / \mathrm{lb} \mathrm{Zn} \text { adopted on basis } \\
\text { Bureau of Mines, Reno. Nevada }(34) \text {. }\end{array}$ & of $1.6 \mathrm{kwh} / 1 \mathrm{~b}$ \\
\hline (d) & Reference (39). & 2 & \\
\hline
\end{tabular}

The difference between the 5.9 months calculated above and the 2 months calculated earlier is the result of a more realistic estimate of the power efficiency of the $\mathrm{ZnCl}_{2}$ electrolysis step, of including the energy requirements of the make-up zinc and the caustic used to neutralize the waste $\mathrm{SiCl}_{4}$ and $\mathrm{Cl}_{2}$ which had not been included earlier, making a more detailed examination of power losses from the $1000 \mathrm{MT} /$ year plant, and adopting a more realistic value for the loss of material in manufacture of the cell from the polycrystalline product. Although not as optimistic as the 2 months estimated earlier, the 5.9-month energy payback time is presumed to be an acceptable value. 


\section{F. CONCLUSION}

In view of the favorable indications of technical feasibility, economic feasibility, and reasonable energy payback time of the process, it is recommended that the construction and operation of the $50 \mathrm{MT} /$ year experimental facility be initiated. 


\section{REFERENCES}

(1) Blocher, J. M., Jr., Browning, M. F.; et al., "Evaluation of Selected Chemical Processes for Production of Low-Cost Silicon", Quarterly

Progress Reports, ERDA/JPL 954339-76/1 through -78/10.

(2) Hunt, L. P., and Strtl, E., "A Thorough Thermodynamic Evaluation of the Silicon-Hydrogen-Chlorine System", J. Electrochem. Soc., 119 (12), 1741 (1972).

(3) Hunt, L. P., and Sirt1, E., "The Equilibrium Behavior of the 3iliconHydrogen-Bromine and S1IIcon-Hydrogen-IodIne Systems", J. Electrochem. Soc., 120 (6), 806-811 (1973).

(4) Stull, D. R., et al., JANAF Thermochemical Tables, Dow Chemical Corporation, Midland, Michigan.

(5) Peters, M. S., and T1mmerhaus, D. K., "Plant Design and Economics for Chemical Engineers", Second Edition, McGraw-H111, Inc., New York, New York (1968).

(6) Arles, R. S., and Newton, R. D., "Chemical Engineering Cost Estimation", McGraw-H111, Inc., New York, New York (1955).

(7) Winfleld, M. D., and Dryden, C. F., "Chemfcal Engineering Costs", Department of Chemical Engineering, The Ohto State University (621-1) (1962).

(8) "Chemical EngIneering", McGraw-Hill, Inc., New York, New York.

(9) Personal communication with L. Hunt, Dow Corning Corporation, Hemlock, Michigan.

(10) Chemlcal Marketing Reporter (January 6, 1975).

(11) Hunt, L. P., "Low Cost Processes for Integrated Solar Arrays", Second Quarterly Progress Report to NSF (RANN) under University of Pennsylvania Grant No. GI-29729 (October, 1974).

(12) Personal communication with G. F. Wakefleld, Texas Instruments, Inc., Dallas, Texas.

(13) Lead and Z1nc Stat1st1cs, XVI (1) Monthly Bulletin of the Internat1onal Lead and Zinc Study Group (January, 1976).

(14) Unpublished BCL work for Industrial sponsors. 
(15) Personal communication with Dr. V. Stenger (retired), Dow Chemical Company, Midland, Michigan (March 10, 1976).

(16) Threlfall, R., "The Electrolysis of Molten Zinc Chloride", Journal of the Society of Chemical Industry, Trans. 48, 210-223 (1929).

(17) Shanks, D. E., Haver, F. P., Elges, C. H., and Wong, M. M., "Electrowinning Zinc from Zinc Chloride-Alkali Chloride Electrolytes", U.S. Bureau of Mines Report of Investigation (to be published, 1978).

(18) Hansen, K. C., Miller, J. W., Jr., and Yaws, C. L., "Process Feasibility Study in Support of Silicon Material Task I", Quarterly Progress Report (VI), ERDA/JPL 954343-77/1 (March, 1977).

(19) Meisel, G. M., "New Generation Zinc Plants, Design Features, and Effects on Costs", Jo,urnal of Metals, 26 (8), 25-32 (August, 1974).

(20) "Industrial Engineering Study of Industrial Chemicals", International Research and Development Corporation to U.S. Department of Commerce and FEA (August 30, 1974).

(21) Fairchild, W. T., Trans. Met. Soc. AIME, Paper No. A70-36 (1970).

(22) Reigel, E. R., "Industrial Chemistry", Reinhold, New York, New York (1949).

(23) Personal communication with D. W. Lyon, DuPont Company.

(24) Bertrand, L., and Olson, C. M., Patent (to E. I. duPont de Nemours and Company), U.S. Patent No'. 3,012,862 (December 12, 1961).

(25) NBS Technical Note 270-3 (January, 1968).

(26) Cubiciott1 and Eding, J. Chem. Phys., 40, 978 (1964).

(27) Kubachewsk1 and Evans, "Metallurgical Thermochemistry", John Wiley and Sons, New York, New York (1956).

(28) Keneshea, F. J., and Cubiciotti, D., J. Chem. Phys., 40 (1), 191-199 (1964).

(29) Brewer, L., et al., "Fusion and Vaporization Data of the Halides", The Chemistry and Metallurgy of Miscellaneous Materials, IV, 19B, L. L. Quill, Ed1tor, McGraw-H111 Book Company, New York, New York (1950).

(30) Stull, D. R., and Sinke, G. C., "Thermodynamic Properties of the Elements", Advances in Chemistry Serles No. 18, American Chemical Soclety (1956).

(31) Kun11, D., and Levenspiel, 0., "Fluld1zat1on Eng1neer1ng", Chapter 11, John Wiley and Sons, New York, New York (1969). 
(32) Fray, D. J., J. App1. Electrochem:, 3, 103-112 (1973).

(33) Haver, F. P., Shanks, D. E., Bixby, D. L., and Wong, M. M., U.S. Bureau of Mines Report of Investigation 8133 (1976).

(34) Visit of J. M. Blocher, Jr., to U.S. Bureau of Mines, Reno, Nevada (June 16, 1977).

(35) Hopkins, R. H., McCormick, J. R., et al., "Silicon Materials. Task of the Low-Cost Solar Array Project (Part 2), Westinghouse Research Laboratories and Dow Corning Corporation, DOE/JPL-Westinghouse Contract No. 954331.

(36) Gutsche, H. W., et al., "Determination of a Definition of Solar-Grade Silicon", Monsanto Research Corporation, DOE/JPL 954338.

(37) Heft, R., "Studies for the Analysis of Trace kilements In HLyll-Puíty Silicon", Lawrence Livermore Laboratories, Livermore, California, Contract NAS7-100.

(38) "Design of $50 \mathrm{MT} /$ Year Experimental f'acil1cy, Design Package", Jubmittad to JPL April, 1978, as specified by DOE/JPL Contract No. 954339.

(39) Hunt, L. F., Proceedings of the 12th Photovoltaic Conference, IEEE, D. 347 . 